UNIVERSIDADE DE SÃO PAULO

FACULDADE DE ECONOMIA, ADMINISTRAÇÃO E CONTABILIDADE DEPARTAMENTO DE ADMINISTRAÇÃO

PROGRAMA DE MESTRADO PROFISSIONAL EM EMPREENDEDORISMO

A CAPTAÇÃO DE RECURSOS DE EMPREENDIMENTOS SOCIOCULTURAIS NO ESTADO DE SÃO PAULO

Renata Roquetti Saroute

Orientadora: Profa. Dra. Ana Cristina Limongi França

SÃO PAULO 
Prof. Dr. Vahan Agopyan

Reitor da Universidade de São Paulo

Prof. Dr. Adalberto Américo Fischmann

Diretor da Faculdade de Economia, Administração e Contabilidade

Prof. Dr. Roberto Sbragia

Chefe do Departamento de Administração

Prof. Dr. Marcelo Caldeira Pedroso

Coordenador do Programa de Mestrado Profissional em Empreendedorismo 


\section{A CAPTAÇÃO DE RECURSOS DE EMPREENDIMENTOS SOCIOCULTURAIS EM SÃO PAULO}

Dissertação de Mestrado apresentada ao Programa de Mestrado Profissional em Empreendedorismo do Departamento de Administração da Faculdade de Economia, Administração e Contabilidade da Universidade de São Paulo, como requisito parcial para a obtenção do título de Mestre em Ciências.

Orientadora: Profa. Dra. Ana Cristina Limongi França

SÃO PAULO 


\section{FICHA CATALOGRÁFICA}

Elaborada por Martha Ribeiro Neves de Vasconcellos - CRB-8/5998 Seção de Processamento Técnico do SBD/FEA/USP

Saroute, Renata Roquetti

A captação de recursos de empreendimentos socioculturais no

Estado de São Paulo / Renata Roquetti Saroute. - São Paulo, 2018. $151 \mathrm{p}$.

Dissertação (Mestrado) - Universidade de São Paulo, 2018.

Orientador: Ana Cristina Limongi-França

1. Empreendedorismo social 2. Empreendedorismo sociocultural 3. Leis de incentivo 4. Captação de recursos 5. Cultura 6. Terceiro setor I. Universidade de São Paulo .Faculdade de Economia, Administração e Contabilidade. II. Título. 
A todos os produtores culturais e artistas, que trabalham diariamente, com paixão, verdade e ética.

Às pessoas que recebem e que podem vir a receber, um dia, o presente de conviver com a arte.

Ao meu filho amado Bento e ao meu marido, amigo e companheiro amoroso Rodrigo. 



\section{AGRADECIMENTOS}

Agradeço, primeiramente, à minha irmã Dúnia, que sem ela este trabalho não teria sido concebido!

Agradeço aos meus colegas de Mestrado pela jornada até aqui e conhecimentos partilhados, ao longo de todo o processo de formação acadêmica.

Agradeço aos meus pais, Nader e Nágila, pelo privilégio de viver e aprender todos os dias!

Agradeço ao meu irmão Ally, ao meu sobrinho Pedro, à minha cunhada Irene e à minha sogra querida Adriana, parte sine qua non de minha família nesta jornada!

Agradeço à minha orientadora Profa. Dra. Ana Cristina, pela chance de realizar este trabalho de forma livre para propor.

Agradeço aos irmãos Luiz, da copiadora da FEA, pelo carinho e cuidado nas formatações de página desta tese! : :)!

Agradeço e dedico, por fim, este trabalho ao meu filho Bento e ao meu amor maior, de todos os dias, Rodrigo. 

É nossa obrigação à Terra torná-la melhor do que a encontramos para as novas gerações. 



\section{RESUMO}

O presente trabalho visa compreender teórica e empiricamente como empreendimentos socioculturais, com sedes e iniciativas no Estado de São Paulo, captam os seus recursos financeiros, sob três aspectos principais: estratégia, estrutura e fontes de captação de recurso. Entende-se como empreendimentos socioculturais, aqui nomeados, as iniciativas que utilizam a cultura e a arte como ferramentas de transformação social, objetivando o acesso à cultura artística, bem como à formação educacional, por via das mesmas, de indivíduos que não poderiam vivenciá-las devido às suas condições sociodemográficas, socioeconômicas e/ou físico-intelectuais. Para isto, foram analisados seis empreendimentos socioculturais, são eles: BuZum Produções Artísticas; ImageMagica Organização Cultural da Sociedade Civil; Doutores da Alegria - arte na promoção da saúde, na formação e no desenvolvimento social; Ibirajá Produções Culturais; Companhia Pia Fraus de Teatro e Cia Vagalum Tum Tum de Teatro Infantil - todos ativos no estado de São Paulo. A pesquisa foi de natureza aplicada, exploratória e qualitativa, utilizando-se a estratégia de estudos de casos múltiplos. Com coleta de dados secundários, através de análise documental e de arquivos somada à coleta de dados primários, através de entrevista estrutura com questionário de perguntas abertas. Os resultados consolidados evidenciaram que não é possível traçar um modelo único para a captação de recursos de empreendimentos socioculturais, mas é possível traçar estratégias e estruturas, que podem ser replicadas, afim de se ter sucesso na obtenção de recursos, nas mais variadas fontes disponíveis.

Palavras-chave: Empreendedorismo sociocultural, sustentabilidade financeira, captação de recursos, incentivos fiscais, terceiro setor, cultura, arte, economia criativa, leis de incentivo. 


\begin{abstract}
This work aimed to understand theoretically and empirically as socio-cultural enterprises, with headquarters and initiatives located in the State of São Paulo, are seeking their financial resources. It is understood as socio-cultural enterprises, here named, the initiatives that uses culture and art as a tool of social transformation, objectifying the access to the artistic culture, as well as to the educational formation, aiming to attend individuals would not experience it, due to their socio-demographic, socioeconomic and/or physical-intellectual conditions. In this regard, six socio-cultural projects were analyzed; which are: BuZum Artistic Productions, ImageMagica civil society organization; Doctors of Joy; Ibirajá Cultural Production; Pia Fraus' Company Theatre and Vagalum Tum Tum Children's Theatre Company - all assets in the State of São Paulo. The research was applied, exploratory and qualitative, using the strategy of multiple case studies. With secondary data collection, through documentary and file analysis added to the primary data collection, by structural interview with questionnaire with open questions. The consolidated results showed that it is not possible to trace a single model for the acquisition of resource for socio-cultural enterprises, but it is possible to replay strategies and structures to obtain success in the acquisition of resources.
\end{abstract}

Keywords: Socio-cultural entrepreneurship, financial sustainability, fundraising, tax incentives, third sector, art, culture, creative economy, incentive laws. 


\section{SUMÁRIO}

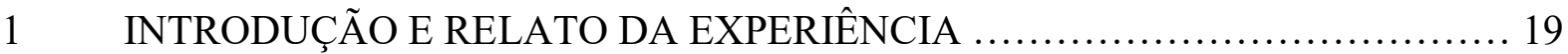

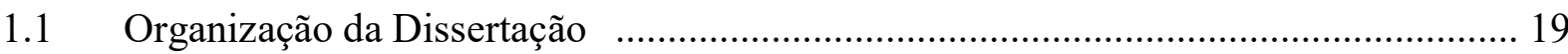

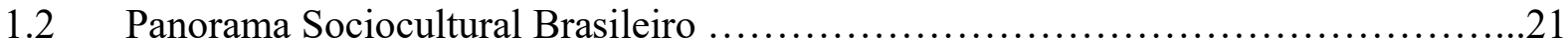

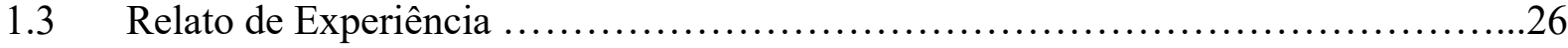

1.4 Problemática observada e questão de pesquisa..........................................................32

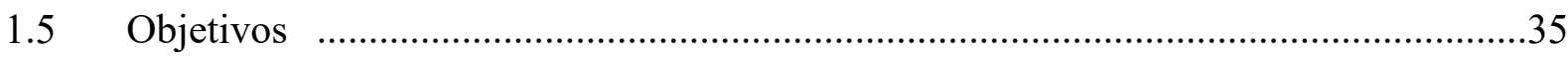

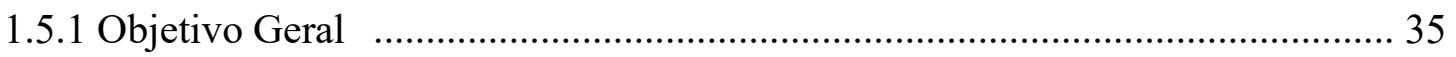

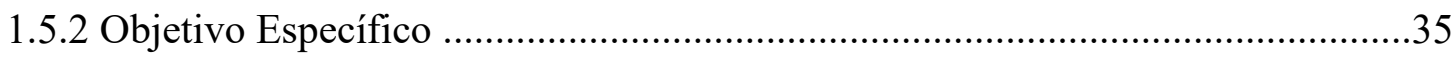

2 REFERENCIAL TEÓRICO............................................... 37

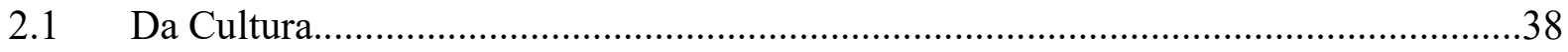

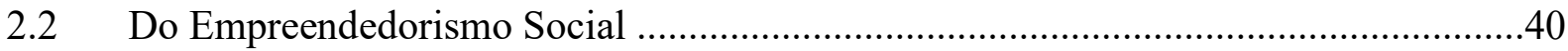

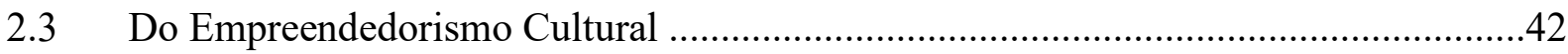

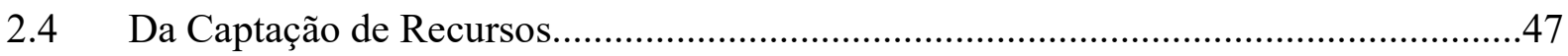

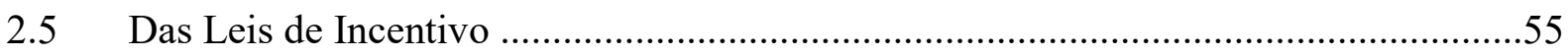

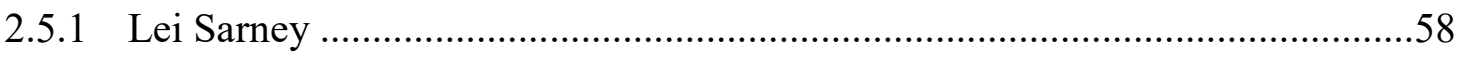

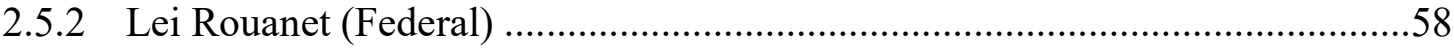

2.5.3 Lei Estadual da Cultura (ProAc | ICMS do Estado de São Paulo) ....................63

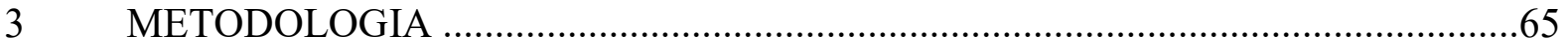

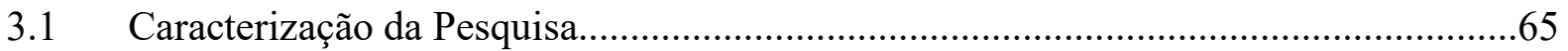

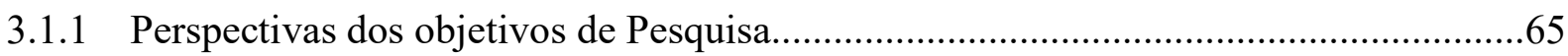

3.1.2 Perspectivas do "meio" para se alcançar os resultados/ Estratégias de Pesquisa.........66

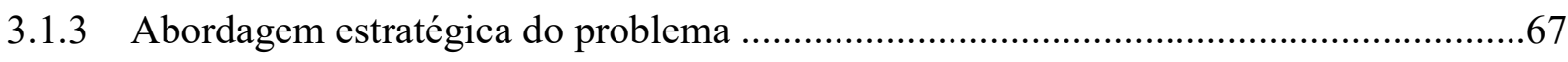

3.1.4 Perspectiva de Utilização dos Resultados Obtidos.....................................................68

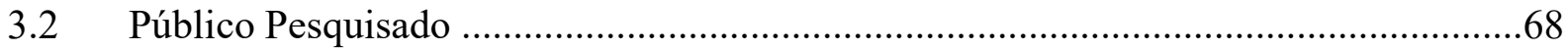

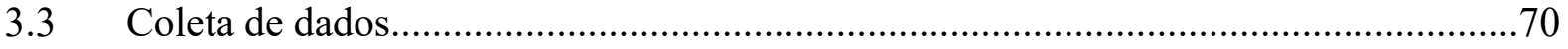

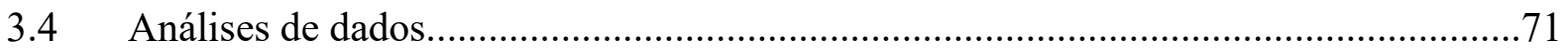

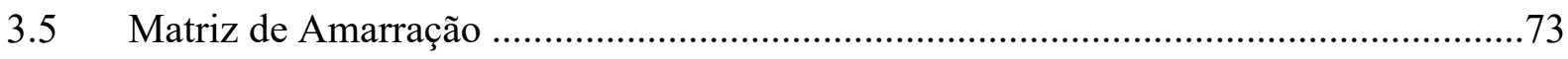

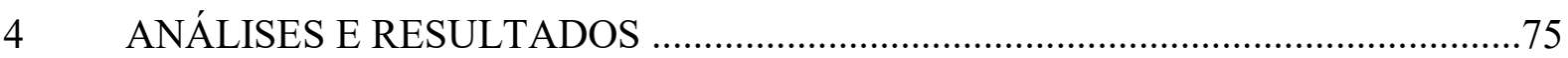

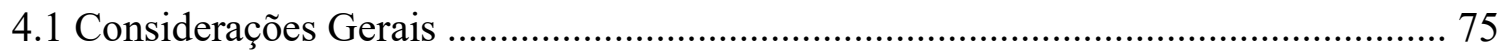

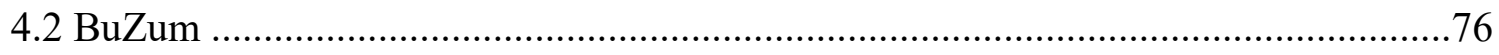

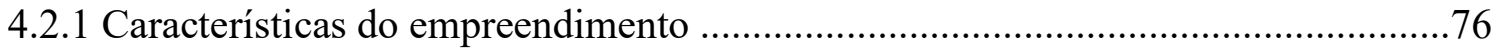


4.2.2 Projetos socioculturais.

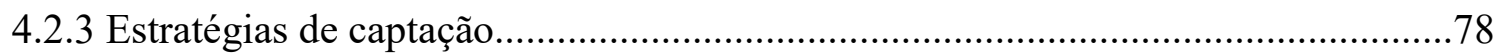

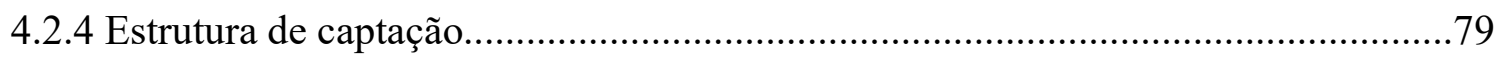

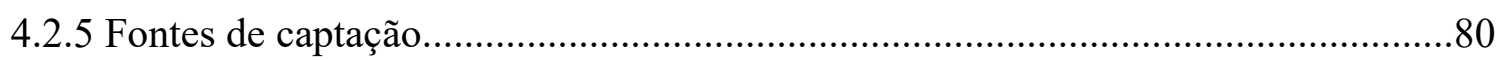

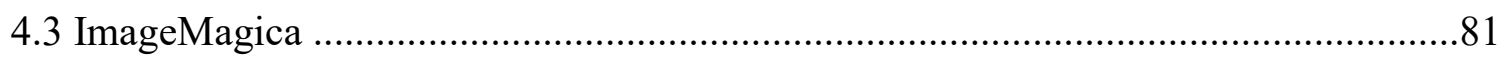

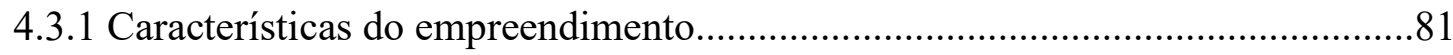

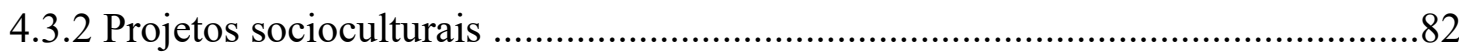

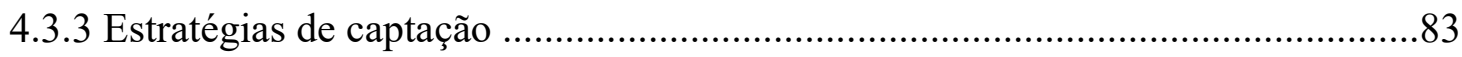

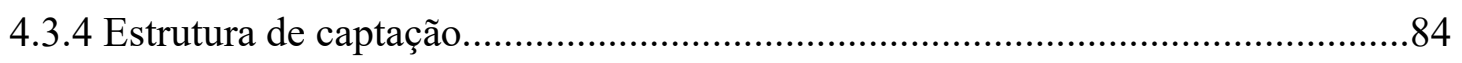

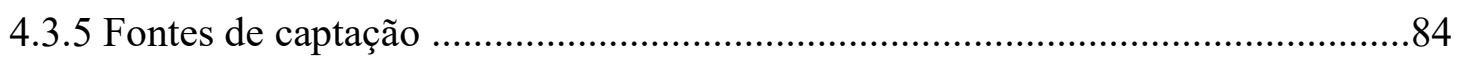

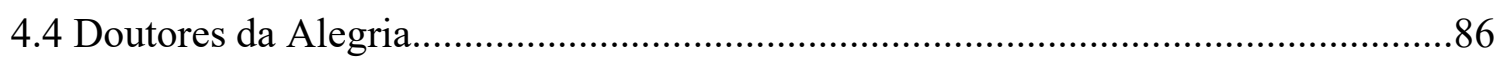

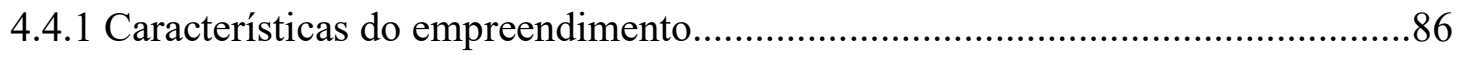

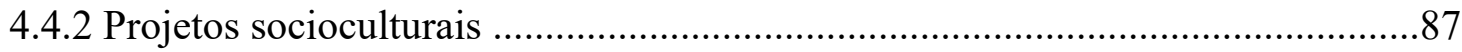

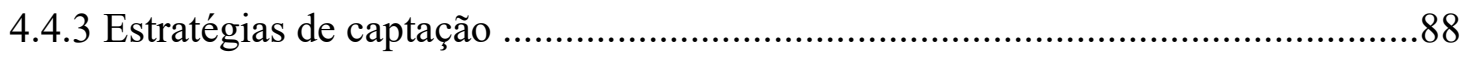

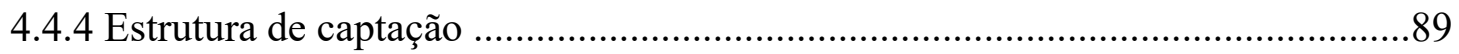

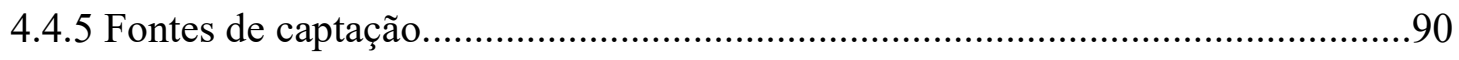

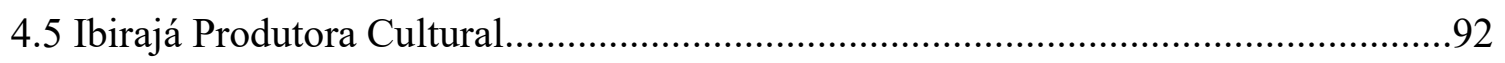

4.5.1 Características do empreendimento ............................................................92

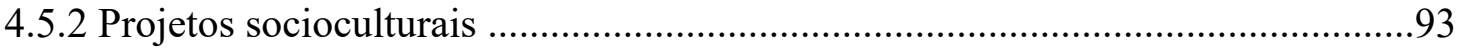

4.5.3 Estratégias de captação ...................................................................................93

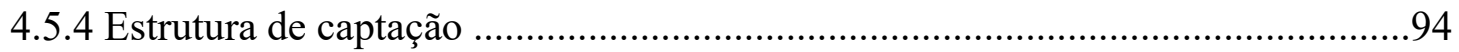

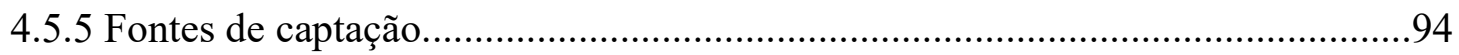

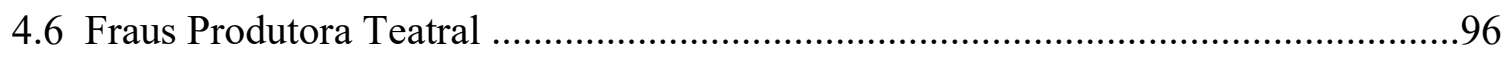

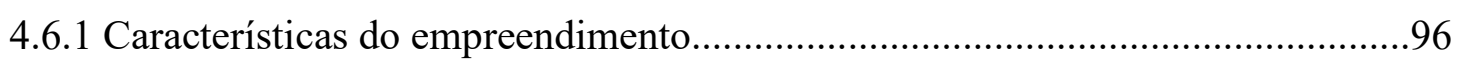

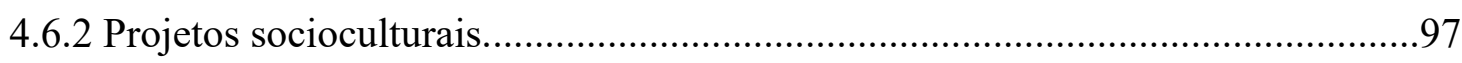

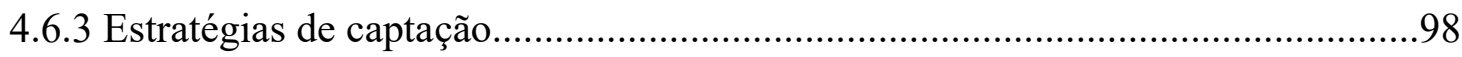

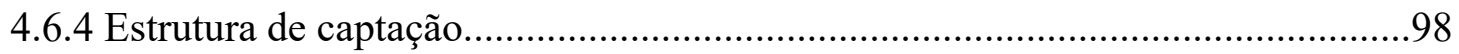

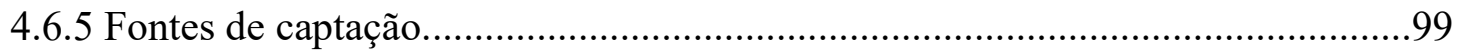

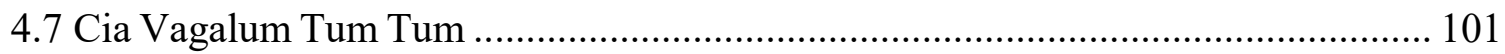

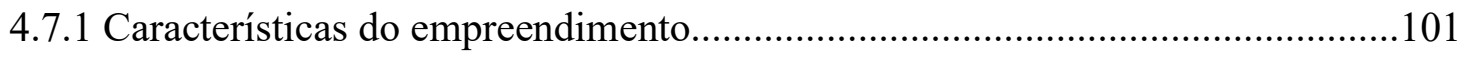

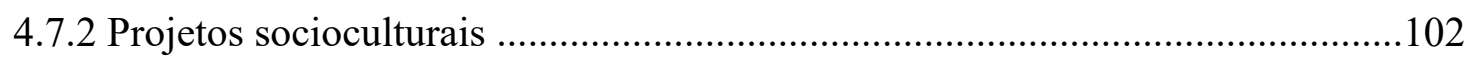

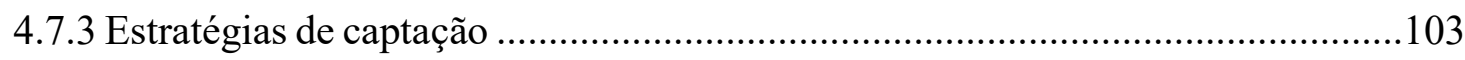

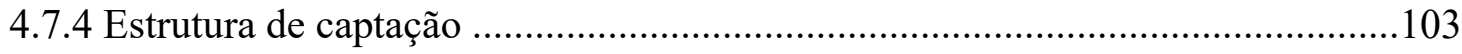

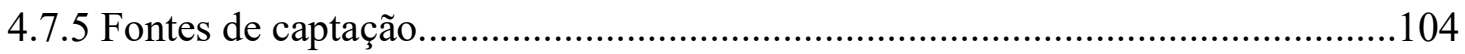




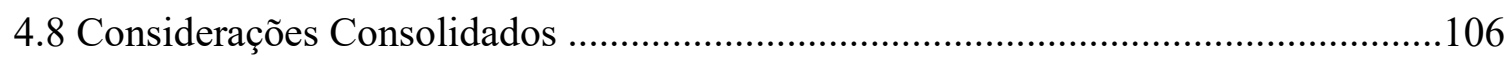

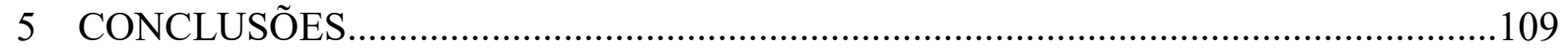

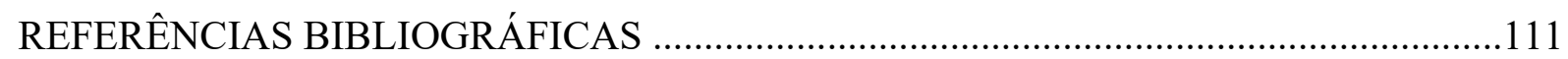

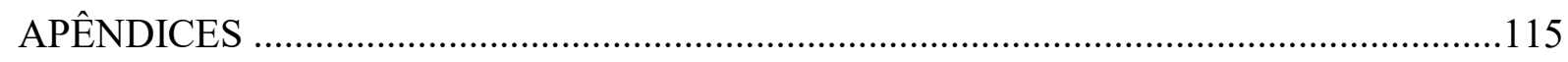

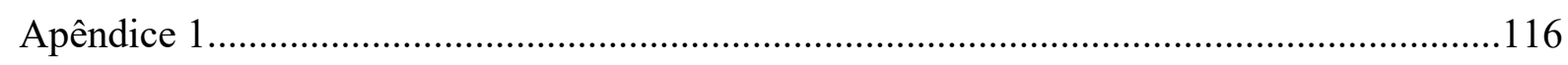

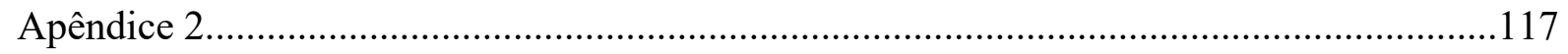

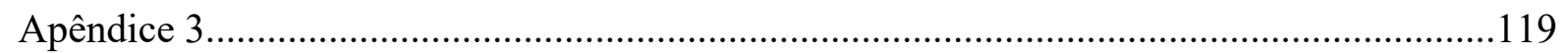

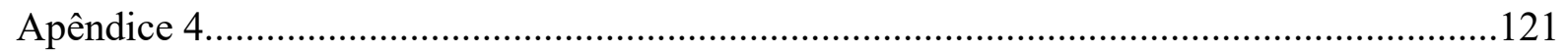

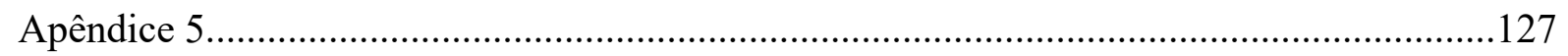

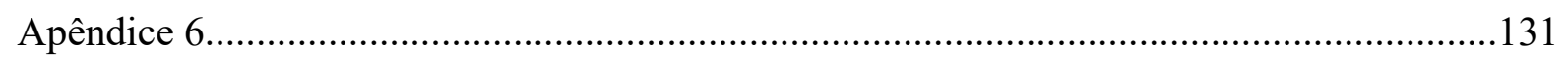

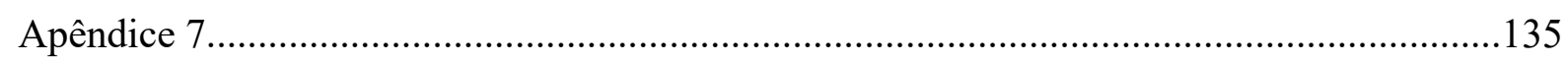

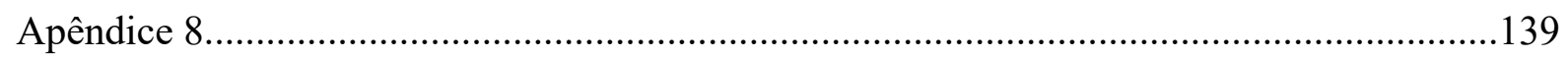

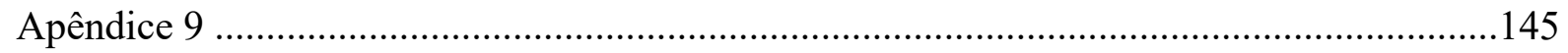





\section{LISTA DE ABREVIATURAS E SIGLAS}

ABCR: Associação Brasileira de Captadores de Recurso

CNAE: Classificação de Atividade Econômica

CRM: Customer Relationship Management

FICART: Fundo de Investimento Cultural e Artístico

FNC: Fundo Nacional da Cultura

FTFS: Força Tarefa de Finanças Sociais

FUMCAD: Fundo da Criança e do Adolescente

IBGE: Instituto Brasileiro de Geografia e Estatística

ICE: Instituto de Cidadania Empresarial

OMS: Organização Mundial de Saúde

ONG: Organização Não Governamental

ONU: Organização das Nações Unidas

OSC: Organização da Sociedade Civil

PROAC: Programa de Ação Cultural

PRONAS/PCD: Programa Nacional de Apoio à Atenção da Saúde da Pessoa com Deficiência PRONON: Programa Nacional de Apoio à Atenção Oncológica

SEBRAE: Serviço Brasileiro de Apoio às Micro e Pequenas Empresas

SESC: Serviço Social do Comércio

SESI: Serviço Social da Indústria

UNCTAD: Conferência das Nações Unidas sobre Comércio e Desenvolvimento

UNESCO: Organização das Nações Unidas para a Educação, Ciência e Cultura 


\section{LISTA DE QUADROS}

Quadro 1 - 10 maiores produtores por volume captado na Lei Rouanet 2015

Quadro 2 - Valores Aportados por fonte

Quadro 3 - Estratégias por apoiadores de causa

Quadro 4 - Estratégias por tipo de geração de renda

Quadro 5 - Organismos nacionais de fomento

Quadro 6 - Diferenças entre leis

Quadro 7 - Diferenças entre impostos e limites de renúncia por lei | fundo

Quadro 8 - Número de projetos aprovados por estado | Lei Rouanet 2017

Quadro 9 - Número de projetos com recursos recebidos por estado | Lei Rouanet 2017

Quadro 10 - Número de projetos apresentados por estado | Lei Rouanet 2017

Quadro 11 - Diferenças entre pesquisa qualitativa e quantitativa

Quadro 12 - Empreendimentos Socioculturais

Quadro 13 - Função do Entrevistado e Natureza Jurídica

Quadro 14 - Quadro Meio e Duração das Entrevistas

Quadro 15 - Matriz de amarração de pesquisa 


\section{LISTA DE FIGURAS}

Figura 1 - O que é um Negócio de Impacto

Figura 2 - Escopo dos Setores Criativos

Figura 3 - Ônibus do BuZum

Figura 4 - PhotoTruck

Figura 5 - Artista do Doutores da Alegria em atuação em hospital

Figura 6 - Fontes de Recursos Doutores da Alegria

Figura 7 - Projeto Cine em Cena

Figura 8 - Projeto Bichos do Brasil

Figura 9 - Encenação de peça da companhi 



\section{INTRODUÇÃO E RELATO DA EXPERIÊNCIA}

\subsection{Organização da dissertação}

Esta pesquisa nasceu dentro de um Programa de Mestrado Profissional, cujo objetivo é, além da formação acadêmica, produzir conhecimento científico à luz da experiência vivenciada por cada aluno/pesquisador.

Esta vivência da experiência pode ser desde o problema de pesquisa, apresentado ao aluno, em sua vida prática até a intervenção propriamente dita, criada ou vivida pelo aluno para resolução deste problema.

Esta pesquisa nasceu de uma vivência de experiência, da autora deste trabalho, com relação à obtenção de recursos para financiar iniciativas culturais com fins sociais. Resumidamente, a autora, ao se deparar com o desafio de financiamento, percebeu a oportunidade de criar um negócio que viabilizasse estas iniciativas, através da mobilização ou, como o ecossistema cultural prefere nomear, a captação de recursos.

Esta pesquisa tem como questão principal a investigação, teórica e empírica, de como empreendimentos socioculturais, com sedes e iniciativas no Estado de São Paulo, captam os seus recursos financeiros. Esses empreendimentos são: BuZum Produções Artísticas; ImageMagica Organização Cultural da Sociedade Civil; Doutores da Alegria - arte na promoção da saúde, na formação e no desenvolvimento social; Ibirajá Produções Culturais; Companhia Pia Fraus de Teatro; e Cia Vagalum Tum Tum de Teatro Infantil.

A dissertação, que se segue, espera honrar a cada um destes empreendimentos, que expuseram as suas questões com o objetivo de contribuir para a disseminação e produção de conhecimento. Ela está organizada em cinco partes, que se seguem:

No primeiro capítulo, aqui iniciado e nomeado INTRODUÇÃO E RELATO DA EXPERIÊNCIA, traz, além desta organização, um panorama sociocultural brasileiro, seguido do relato de experiência e a questão de pesquisa gerada, bem como pontua os objetivos desta pesquisa.

Já a segunda capítulo, nomeado REFERENCIAL TEÓRICO, está dividida pelos principais temas aos quais fez-se necessário a busca de embasamento teórico para a construção da presente dissertação. Nele será possível perceber a dificuldade em se enquadrar o tema nas áreas da literatura, devido ao seu recorte específico - sociocultural - bem como escassez de 
literatura brasileira para a realidade nacional no captar recursos para os fins propostos por este estudo.

O terceiro capítulo, nomeado METODOLOGIA, trará as características metodológicas da pesquisa: desde a caracterização desta até a matriz de amarração criada para desenvolvê-la.

O quarto capítulo, nomeado ANÁLISES E RESULTADOS, traz as análises e resultados da pesquisa. Primeiramente, divididos por cada um dos seis empreendimentos estudados e ao final com um apanhado consolidado dos resultados encontrados.

Por fim, no quinto e último capítulo, nomeado CONCLUSÕES, falaremos do que era esperado, ao início desta pesquisa e o que foi encontrado; sendo possível enumerar limitações do estudo e sugestões de estudos futuros.

Há também as REFERÊNCIAS BIBLIOGRÁFICAS E OS APÊNDICES, este último formado do protocolo para estudo de caso, questionário de pesquisa e entrevistas transcritas. Das entrevistas transcritas: será possível verificar que nem todos os empreendimentos responderam à totalidade das perguntas, isto se deve ao fato simplesmente de que algumas perguntas não eram pertinentes à realidade do empreendimento. 


\subsection{Panorama Sociocultural Brasileiro}

Um dos maiores desafios de qualquer empreendimento social ${ }^{1}$ no Brasil é a sua sustentabilidade financeira a médio e longo prazo. Ainda, quando o conceito de empreendedorismo social está associado à cultura, unindo-se estas duas razões de existir, assim chamado empreendimento sociocultural ${ }^{2}$, o desafio sustentável é mais acentuado.

Certamente, para que um empreendimento sociocultural consiga viabilizar suas causas e atuações sociais faz-se necessário o desenvolvimento de duas vias fundamentais: a primeira, a via da captação de recursos e a segunda, a via da gestão dos mesmos, é preciso geri-los adequadamente de modo a garantir a sustentabilidade financeira do empreendimento.

Porém, embora ambos espectros sejam de igual relevância, pontua-se, que o foco deste trabalho se concentrou primordialmente na primeira via, ou seja, na captação e na obtenção de recursos financeiros, com especial referimento ao impacto da legislação de incentivos fisscais, que chega ao Brasil na década de 1990, e é, atualmente, o principal mecanismo de fomento à cultura no país ${ }^{3}$. As ferramentas para geri-los, no momento, não serão o foco deste estudo, mas, por certo, poderão aparecer em dados coletados ao longo da pesquisa.

Em perspectiva histórica, a raiz da captação e obtenção de recursos para a cultura remonta da antiguidade clássica com a prática do mecenato. De acordo com Reis (2006), o termo mecenato, parece ter sido forjado da referência às atividades desenvolvidas por Gaius Maecenas, amigo pessoal do imperador Caio Augusto e grande articulador das ligações entre o estado romano e o sistema das artes. Posteriormente, atingindo grande prestígio na sociedade clássico-renascentista ${ }^{4}, \mathrm{o}$ fomento à cultura e a arte se dava através do mecenato enquanto forma deste expressar e legitimar à sociedade o poderio e a riqueza de uma determinada família.

Já no final do século XIX e início do século XX, épocas de formação e consolidação de grandes fortunas modernas, notadamente no contexto norte-americano, o mundo das artes passa a assistir as práticas da nomeada filantropia. Nisso, nomes como Henry Frick, o doador

\footnotetext{
${ }^{1}$ Toma-se a terminologia Empreendimento Social de acordo com as definições de: Yunus (2000), Drucker (1985), Fischer (2011).

${ }^{2}$ Os estudos que focam suas significações unicamente na complexidade do empreendedorismo sociocultural são ainda dificilmente delimitáveis.

${ }^{3}$ Disponível em: http://rouanet.cultura.gov.br/. Acesso em: 04 de abril de 2018.

${ }^{4}$ Como se sabe, a Itália, berço do Renascimento, foi também o palco para os investimentos em arte e cultura por uma das famílias mais poderosas do século XV, a família Médici. Governantes de Florença, foram por mais de três séculos os promotores das artes e da cultura renascentista. Para uma análise completa de tais investimentos, sugere-se a leitura do historiador de arte italiano Giulio Carlo Argan (2003).
} 
de mansões e coleções de artes à cidade de Nova York; Andrew Carnegie, personalidade associada ao Carnegie Hall e a Fundação Carnagie; e David Rockefeller, dono do sobrenome que leva até os dias de hoje a Fundação Rockefeller, são tidos como os baluartes dos modelos de investimento no desenvolvimento cultural de uma nação. Em fato, segundo analisa Reis (2006), David Rockefeller, em 1966, profere um discurso exortando às empresas a participar da vida cultural norte-americana e, disto, o que era filantropia passou, no campo empresarial, a assumir o caráter de responsabilidade social. Reis, ainda destaca:

\begin{abstract}
A responsabilidade social é caracterizada por uma postura ativa e um comprometimento da empresa em não apenas ser ética e assumir a responsabilidade pelo bem-estar de seus funcionários, como também promover o desenvolvimento de comunidade em que atua, em termos econômico, social, ambiental, cultural, político, educacional, de forma integrada com o dia-a-dia de seu negócio. (REIS, 2006, p.10)
\end{abstract}

No Brasil, a filantropia remonta suas raízes em meados do século XVI, com fortes incentivos à área da saúde, e não à área da cultura, através do surgimento das Santas Casas de Misericórdia regidas pela lógica assistencialista e de caridade cristã voltadas para o atendimento de pessoas carentes e sustentadas por ricos filantropos. (ASHOKA, 2006, p.10).

No final do século XIX, o Estado passa a intensificar sua atuação social e as instituições, com características assistencialistas, começam a seguir a orientação administrativa e normativa do Estado. Posteriormente, já em meados do século XX, em contraponto ao controle e ações do Estado, surgem as Organizações Não Governamentais (ONG's) ${ }^{5}$. Por certo, surgidas na década de 1970, as ONG's protagonizaram papel fundamental na conformação do setor social e nos rumos da sociedade brasileira. Historicamente, elas atraiam a filantropia do empresariado brasileiro, os pioneiros dos processos de industrialização da economia nacional; delimitando estas ações à solução paliativa de problemas sociais vivenciados por alguns segmentos da população que estavam ao seu alcance. (FISCHER, 2006, p.152)

Nos anos 90, a disputa por recursos para direcionamento às organizações da sociedade civil, no Brasil, passa a existir de forma mais acentuada devido a, não somente filantropos apoiando o terceiro setor, como também as empresas privadas que viam neste setor a oportunidade de refletirem sua possível causa social. Desta perspectiva, as empresas passavam a elencar seus critérios mínimos para a seleção de instituições e de causas que se identificassem para, então, direcionarem seus recursos. Os escopos iam desde a saúde, educação, fome, cultura,

\footnotetext{
${ }^{5} \mathrm{O}$ termo ONG está comumente disseminado e é utilizado atualmente para designar qualquer tipo de organização sem fins lucrativos tais como OSC (Organizações da Sociedade Civil) (ASHOKA, 2006). Mas, é importante lembrar que o termo é de uso coloquial, pois juridicamente ele é inexistente.
} 
esporte até os direitos humanos de idosos ou de crianças. A medida que adquiriam experiência na área de interesse, constituíam suas próprias fundações, com seus próprios projetos sociais.

Portanto, investir em cultura estava e ainda está entre as inúmeras possibilidades de se praticar responsabilidade social para o setor privado.

Historicamente, por outro lado, a área da cultura no Brasil assistia, até o fim do período colonial, a responsabilidade pública por ela ser praticamente ignorada. Ainda, a corte portuguesa mostrava-se avessa a qualquer incentivo à produção cultural brasileira, segundo Reis (2006). Só em 1845, a coroa passa a custear o Prêmio Viagem, escolhendo anualmente um estudante para mantê-lo no exterior por três anos. A cultura, que se formava e certamente se valorizava, era da promoção da tradição europeia, mesmo havendo, em contexto nacional, artistas como Aleijadinho e outros muitos anônimos, que mesclavam sotaques e heranças de tantos povos, fomentando uma identidade nacional com musicalidades advindas de inúmeros matizes populares. Objetivamente, até os anos do século XX, inexistia no Brasil, uma estrutura administrativa pública encarregada do fomento democrático à promoção cultural e a uma política pública cultural.

Por outro lado, na esfera privada, via-se o incentivo às expressões culturais, caras aos donos dos recursos, na forma de construção de instituições. Exemplos disto foram a formação do primeiro teatro brasileiro, o Teatro Santa Isabel, em Recife (em 1850), cuja a ideia de construir um teatro público partiu de Francisco do Rego Barros, futuro Conde da Boa Vista, presidente da província de 1837 a 1844; seguido pela construção do Teatro Amazonas, em Manaus (em 1896) e os Teatros Municipais do Rio de Janeiro (1909) e de São Paulo (1911); no entanto, em todas as instituições, o que se via eram apresentações de companhias e de obras estrangeiras.

Os mecenas brasileiros, ao longo do século $\mathrm{XX}$, foram os grandes visionários e empreendedores responsáveis por possibilitar efervescência cultural ao pais, principalmente em São Paulo, transformando-a em legítima capital cultural do Brasil. Nomes como José de Freitas Valle, responsável por tornar sua casa um centro de encontro de artistas e de fomento à produção destes, tais como Mário de Andrade, Oswald de Andrade, Lasar Segall, Villa Lobos; como Francisco Matarazzo, o responsável pela inauguração do MAM (Museu de Arte Moderna), MAM que deu origem ao Museu de Arte Contemporânea da USP e à Cinemateca Brasileira, bem como foi o grande responsável pela inauguração da Bienal Internacional de São Paulo; e da coordenação da utilização do Parque do Ibirapuera, com projeto arquitetônico de Oscar Niemeyer e projeto paisagístico de Roberto Burle Marx; como Assis Chateaubriand, que ficou conhecido como um dos homens mais influentes do Brasil por também ter sido o responsável 
pela construção do MASP e conseguir isto com doações de pessoas físicas da elite brasileira, burguesa e rural.

Deu-se a ditadura e somente depois dela é que surgiu o Ministério da Cultura, em 1985. Criada a Lei Sarney para estímulo das empresas privadas e pessoas físicas a fomentarem a cultura, através de benefícios fiscais, ela não foi muito longe, por razões de fraudes e desvios de recursos. Com o governo Collor, o Ministério da Cultura foi rebaixado a Secretaria da Cultura. Em 1991, é criada a Lei Rouanet, que somente com o governo de Itamar Franco passa a ser utilizada, mesmo que a passos lentos.

Hoje, a Lei Rouanet é uma das maiores fontes de recurso para a cultura no Brasil, permitindo que pessoas jurídicas e pessoas físicas invistam em projetos culturais através de benefícios fiscais obtidos. Mas, veremos no relato de experiência e referências bibliográficas, que os empreendimentos socioculturais não são os grandes beneficiários via pessoas jurídicas. Tampouco, pessoas físicas fazem uso da lei na totalidade que esta permite.

Além da Lei Rouanet, há mais de 30 outras leis municipais e estaduais que objetivam a democratização, acesso e formação à cultura e a arte para que a iniciativa privada em parceria com a pública invista em cultura através de benefícios fiscais. Estas leis permitem dedução de Imposto sobre Serviço - ISS, Imposto Predial e Territorial Urbano - IPTU ou Imposto sobre Circulação de Mercadorias e Serviços - ICMS, limitados às porcentagens por lei e por natureza do imposto empregado. As empresas privadas têm, cada vez mais, utilizado das leis de incentivo fiscal para refletirem posicionamento de marca e garantirem relacionamento com seus stakeholders.

Se o uso delas é estritamente para projetos socioculturais, que visem acesso à população que não pode tê-lo, seja em termos demográficos, seja em termos de gratuidade, esta é uma outra questão a ser estudada e analisada. No trabalho, poderemos fazer inferências e traçar percepções de como a utilização das leis podem também afetar a captação de recursos para projetos socioculturais.

Segundo Fischer (2006), a intensidade do interesse do empresariado por Responsabilidade Social pode ser atribuída à:

- Os chamados "problemas sociais" tornam-se barreiras para a modernização dos sistemas produtivos, que necessitam superá-los para atingir padrões mais elevados de competitividade;

- O contexto social contemporâneo impõe às organizações um relacionamento equilibrado com múltiplos stakeholders, que exigem informações transparentes, valores e princípios efetivamente assumidos pelas organizações e seus dirigentes; 
- De forma intencional ou não, as pessoas e organizações responsáveis estão dando mais visibilidade pública às ações sociais que realizam.

Fischer (2012) destaca que as raízes da carência e do pouco desenvolvimento de investimentos com finalidade social, atualmente, seja por meio de políticas públicas, seja por meio de investimentos de empresas privadas, vem de uma agenda onde o 'social' não é visto como tema estratégico, capaz de gerar desenvolvimento econômico e, em razão disso, apenas uma parcela residual de recursos é destinada para esse fim.

Ao analisarmos, sob a ótica de políticas públicas, os empreendimentos socioculturais fazem parte, em âmbito nacional, da agenda do Ministério da Cultura sob o chapéu de Cultura e Economia Criativa, sofrendo impacto direto nas modificações constantes governamentais e da legislação vigente, bem como dos resultados econômicos das organizações privadas, que investem em seus projetos culturais, via incentivos fiscais. Veremos mais sobre este tema na discussão do capítulo referencial teórico, especificamente sobre Leis de Incentivo.

Por outro lado, se fossemos considerar o fator capacidade de desenvolvimento econômico, a Cultura é considerada hoje $4,0 \%$ do PIB brasileiro. ${ }^{6}$

A responsabilidade social, característica de cada organização privada investidora, pode ou não estar refletida em escolhas de projetos socioculturais. Projetos socioculturais, aqui nomeados, são os projetos que utilizam a cultura e a arte como ferramentas para algum tipo de transformação social, que objetivam o acesso à cultura e a arte, bem como a formação educacional em cultura e arte para as pessoas que não poderiam tê-las devido às suas condições socioeconômicas, sociodemográficas e ou físico-intelectuais. Exemplos destes projetos são cursos de música instrumental para crianças e adolescentes carentes, cursos de danças para pessoas com deficiência física e/ou carentes, curso de literatura para adultos carentes e semianalfabetos, entre outros exemplos de projetos que visem proporcionar formação e acesso. Exemplos de projetos que utilizam acentuadamente o acesso e a formação de plateia seriam: projetos de projeção de cinema, num único dia, numa cidade do interior do Nordeste que não tenha sala de cinema; projetos de apresentação de musical em praça pública para comunidades que não podem pagar o valor do ingresso, entre outros.

Aqui, fez-se necessária a reflexão sintética: tanto a responsabilidade social, como a cultura e a arte são temas recentemente vinculados à captação e obtenção de recursos no Brasil, em termos de referências bibliográficas. Os recursos podem vir de fontes privadas, sejam de

\footnotetext{
${ }^{6}$ Essa informação pode ser consultada no própria site do Ministério da Cultura, disponível no seguinte endereço: http://www.cultura.gov.br/noticias-destaques/-/asset_publisher/OiKX3xlR9iTn/content/ministerio-da-culturaretoma-projeto-do-pib-da-cultura/10883. Acesso em: 25 de outubro de 2017.
} 
pessoas físicas ou pessoas jurídicas, bem como de fontes públicas, em esferas federais, estaduais e municipais. Como estas fontes de recurso são acionadas, como é realizado o processo de captação de recursos por eles, considerando a natureza da sua atuação social, sua causa, sua estrutura e estratégias para chegarem às possíveis fontes disponíveis, serão discutidas nos próximos capítulos dessa dissertação.

\subsection{Relato de Experiência}

"Toda pessoa em um enorme potencial e pode influenciar a vida das outras
no seio das comunidades durante sua existência. No fundo de cada um de nós
existem muito mais possibilidades do que aquelas que tivemos ocasião de
explorar até o presente. Cabe a nós decidir que rumo tomaremos. Somos os
pilotos e os navegadores de nosso planeta. Se levarmos a sério nosso papel,
o destino que nos aguarda será necessariamente o que previmos."
(Muhammad Yunus)

A cultura e a arte sempre estiveram presentes no meu cotidiano e na minha forma de refletir sobre as questões e problemáticas humanas, que nos cercam. Não me lembro um só dia que passei sem apreciar uma música ou contemplar a memória de um poema. As expressões artísticas, certamente, são grandes aliadas em tornar as questões práticas cotidianas, e porque não filosóficas, mais fáceis de serem enfrentadas e até resolvidas.

Se por um lado o papel da cultura e da arte aparenta pertencer a uma esfera subjetiva, ou seja, é mais difícil de ter seus efeitos e contribuições mensurados na vida cotidiana dos indivíduos que as apreciam e as "consomem" - por estar intimamente ligado ao campo das emoções, expressas em frases como "sinto-me mais leve ao ouvir uma canção", "estou emocionada ao ver essa peça", entre tantas outras manifestações emocionais; por outro, o papel da arte e da cultura também está representado por contribuições e efeitos objetivos para quem a produz, para quem a "consome" e, certamente, para quem acredita e investe recursos nela. A produção de conhecimento e saber; a formação humana, social, política; a geração de empregos; a formação e construção educacional, são apenas alguns de tantos exemplos concretos que podemos citar para os benefícios práticos do fazer, consumir, aprender e acessar ao artístico.

Além de apreciadora e "consumidora" da arte, estou neste ecossistema como produtora cultural e mobilizadora de recursos para a cultura, sustentando-me financeiramente com a produção de cultura e arte bem como prestações de serviço nesta área. Na infância, fazia peças de teatro, participava de recitais de poesia e saraus de música. Hoje, além de escrever poesias e dar aula de iniciação à escrita poética, sou proprietária da Semente, empresa que existe há dois anos, e que tem como missão levar a Cultura e o Esporte para quem não tem acesso a estas 
ferramentas de transformação social. Acesso, aqui, lê-se como a não possibilidade socioeconômica, sócio - geográfica ou físico-motora de usufrui-las. Resumidamente, nosso modelo de negócio atua, principalmente:

- Na prestação de serviços para produtores culturais e esportivos, bem como fundações ou institutos que tenham a causa social no "DNA", no que tange captação de recursos e desenvolvimento de projetos.

- Na prestação de serviços para empresas privadas no que tange o desenho de política de investimento social e desenvolvimento de projetos culturais e esportivos. Entendemos, que para a nossa missão acontecer, a fonte de recursos que sabíamos potencializar, eram as empresas privadas- devido à experiência de carreira profissional, acumulada pelos sócios, como funcionários de grandes companhias antes de abrirem seus próprios negócios e por esta ser a fonte mais efetiva e transparente, na nossa visão, em termos de escala de investimento financeiro.

A Declaração Universal dos Direitos Humanos prevê o acesso à cultura como um direito fundamental e inalienável de todo e qualquer ser humano, e é nisto que acredito. E complemento que a cultura e a arte exercem papel transformador e construtor na vida das pessoas. Em pequena ou grande escala. Em pequena escala entende-se as nuances subjetivas, tais como a melhoria do estado de humor, da autoestima, da sensibilidade humana. Em grande escala entenda-se algo como o resgate de crianças em situação de risco social pelo ensino de alguma arte, a formação de adolescentes em alguma arte específica e que esta sirva como ofício futuro ou uma contribuição para a melhoria do desempenho escolar, a possibilidade de dar expressão a quem sempre viveu à margem, entre outros tantos exemplos. Acreditando nessa causa, trabalho pelo acesso à arte para quem não pode tê-lo no Brasil, seja por questões sociodemográficas, seja por questões socioeconômicas ou físico-intelectuais. A esse propósito, a Semente produz e capta recursos para seus projetos próprios de arte e presta serviços na cadeia da cultura.

No âmbito dos projetos próprios da empresa, o curso de iniciação à escrita e/ou poesia para mulheres, em situação de vulnerabilidade social, é uma das peças chaves na busca pela expressividade dessas mulheres, através da arte.

Não obstante, no âmbito dos serviços prestados pela Semente, seus escopos objetivam a razão de existir da empresa, ou seja, levar a cultura e a arte a quem não tem acesso a elas. São serviços prestados no ecossistema de cultura para o produtor de arte e cultura, que constituem as empresas ou associações socioculturais, para os institutos e fundações, que tem projetos próprios e para os potenciais investidores, chamados empresas privadas de grande porte. 
Dentro dessa perspectiva, quando direcionados a produtores, fundações e instituições os serviços contemplam consultoria para transformar ideias em projetos culturais; elaboração de projetos culturais; captação de recursos para os mesmos; oficinas sobre captação de recursos e fontes de recursos para investimento social; oficinas sobre o funcionamento completo das leis de incentivo federais, estaduais e municipais; oficinas sobre fundos sociais federais, estaduais e municipais; concepção de indicadores de impacto dos projetos sociais.

Quando direcionados a empresas privadas, os serviços contemplam consultoria para montar plano de investimento social (missão, critérios, planejamento, execução); elaboração de projetos culturais; seleção e curadoria de projetos; acompanhamento de projetos; oficinas sobre captação de recursos e fontes de recursos para investimento social; oficinas sobre funcionamento de todas as leis de incentivo federais, estaduais e municipais; oficinas sobre fundos sociais federais, estaduais e municipais; concepção de indicadores de impacto dos projetos.

Com experiência prévia em captação de recursos para projetos via leis de incentivo, não somente culturais, mas esportivos, sociais e de saúde, foram acumuladas por mim um saber prático na atividade de captação, com foco em encontrar empresas privadas que quisessem investir em projetos de qualquer natureza, via leis de incentivo. Foram mais de 100 empresas abordadas, mais de 100 projetos em leis de incentivo, que tive contato direto ou indireto. Dessas, captou-se recurso via leis de incentivo para mais de 40 projetos incentivados, num montante de R \$ 18 milhões de reais, dividido entre 22 empresas. Na Semente, já são mais de R \$6 milhões de reais captados, para mais de 20 projetos socioculturais e sócio - esportivos.

De tal experiência, alguns fatos merecem ser divididos em três vertentes:

- $\quad$ Recebedor do incentivo fiscal: o empreendimento cultural

- $\quad$ Doador de incentivo fiscal: a empresa privada

- Doador de incentivo fiscal: empresa privada

O comportamento de doação e/ou investimento social direto (com desembolso de dinheiro e sem benefícios fiscais) e indireto (com benefícios fiscais, via leis de incentivo) de empresas privadas, poderia ser dividido em quatro grandes grupos, quanto a forma de doar e a existência de política de investimento social:

I. As empresas privadas que têm políticas de investimento social definidas, geralmente não possuem critérios tão bem estruturados para escolha de seus projetos. E se possuem, também fazem investimento diretos e indiretos em projetos. 
II. As empresas privadas que querem investir em responsabilidade social e não têm políticas de investimento social definidas, geralmente, não possuem um "norte" de como iniciar o investimento seja direto ou indireto.

III. Há muitas empresas que utilizam o recurso disponível em leis de incentivo para fins de posicionamento de marca atrelada a grandes produções artísticas, sem elencarem outros critérios decisórios que possam fazer projetos socioculturais competirem pelo recurso. E estas empresas geralmente possuem ou não sócios que fazem doação direta a instituições, sem necessariamente serem instituições com fins socioculturais.

IV. Há muitas empresas que não querem se utilizar de leis de incentivo ou fazer doações por desconhecimento de como funcionam as leis ou por não possuírem uma área de responsabilidade social que cuide de projetos.

Importante salientar que a percepção sobre o funcionamento da decisão sobre investimento direto, nas empresas privadas, foi desenvolvido por curiosidade da autora, pois o foco do meu trabalho era a captação de recurso via investimento indireto, por leis de incentivo; mas, percebia a importância de compreender o mecanismo de escolha de projetos para investimento social direto, afim de traçar paralelos para a escolha e direcionamento dos projetos com investimento indireto (via leis de incentivo), garantindo assim uma coesão na escolha destes, bem como na definição do que apresentar às empresas, garantindo assim a sustentabilidade da política de investimento social destas.

\section{- Recebedor do incentivo fiscal: o empreendimento cultural}

Ao longo da minha experiência, percebi que o perfil das empresas privadas e a existência de política de investimento social dentro delas influenciam diretamente nas escolhas de projetos aos quais estas vão direcionar seus recursos diretos ou indiretos.

Quando a empresa está no terceiro grupo, projetos socioculturais dificilmente são escolhidos por elas para receberem recursos, quando a empresa está nos demais grupos, projetos socioculturais podem vir a ser escolhidos por elas e disto dependem vários fatores internos, controláveis pelos empreendimentos socioculturais, realizadores dos projetos, bem como fatores externos, não controláveis por estes.

Os fatores internos, percebidos ao longo da minha experiência, eram principalmente:

I. $\quad \mathrm{O}$ conhecimento sobre as fontes de recursos disponíveis para captá-los como o equivalente ao que uma área de Marketing e/ou Vendas de uma empresa acumula sobre seus potenciais clientes, quem são, onde estão, entre outras variáveis; 
II. A estrutura organizacional de captação ou mobilização de recurso do empreendimento, refletida no número de pessoas dedicadas à captação e no perfil das pessoas, que compõem a estrutura. Traçando, também um paralelo com o mundo corporativo, seria o equivalente à equipe de Vendas de uma empresa;

III. A credibilidade e a seriedade do interlocutor do projeto, indivíduo este que, geralmente, compõe a estrutura organizacional na área ou na função de captação ou mobilização de recurso do empreendimento;

IV. A missão e a causa do empreendimento e do projeto sociocultural;

V. $\quad$ A apresentação formal adequada deste projeto;

VI. A consistência do projeto em termos de indicadores sociais como número de pessoas beneficiadas, número de cidades beneficiadas, duração do projeto, entre outros;

VII. O histórico de patrocínio do projeto;

VIII. O histórico de vida do projeto e da associação;

IX. Os prêmios e reconhecimentos públicos ou privados da associação e de seus projetos,

X. Entre outros fatores que contribuam para a solidez do empreendimento e seu projeto sociocultural.

Partindo-se da premissa que o empreendimento já tem um trabalho consistente, os itens IV à X estão ligados diretamente à atuação sociocultural do empreendimento, podendo existir e estarem apresentados adequadamente ou existirem e necessitarem de ajustes na forma de organizá-los, geri-los ou apresentá-los, já os itens de I à III poderiam impactar diretamente no processo de captação de recursos, pois não dependiam da atuação social da organização, mas sim ligados direta e estritamente ao processo de captação.

Os projetos geralmente estavam em associações culturais que possuíam uma causa e uma atuação social relevantes, executavam seus projetos, mas tinham dificuldades em desenvolverem ferramentas, traçarem estratégias e acumularem inteligência de informações, como as resumidas nos principais processos internos abaixo:

I. Traçarem as estratégias gerais do empreendimento;

II. Traçarem as estratégias de captação do empreendimento, que deveriam incluir: identificarem fontes de recursos; buscarem estas fontes de recursos; acionarem estas fontes de recursos; captarem e obterem seus recursos assim como uma área de vendas deve funcionar para empresas privadas; 
III. Manterem relacionamento com suas fontes de recurso, objetivando a renovação de ciclo de investimentos assim como uma área de pós-venda/relacionamento deve funcionar para empresas privadas;

IV. Criarem banco de dados, antes, durante e após este ciclo, tornando-o uma ferramenta estratégica, na captação de recursos, assim como um CRM deveria funcionar para empresas privadas.

E assim, consequentemente, poderiam perder a chance de participarem de processos de captação de recursos. Logo, terem estes fatores e processos internos bem estruturados não garantiria a captação, mas poderia contribuir para o sucesso dela, na minha percepção.

Um item importante dos fatores internos acima são o conhecimento das possíveis fontes de recursos disponíveis a projetos socioculturais, que podem ser:

- Doações diretas de pessoas físicas

- Doações diretas de pessoas jurídicas

- Doações ou patrocínios de pessoas físicas, via lei de incentivo federal ${ }^{7}$

- Doações ou patrocínios de pessoas jurídicas, via lei de incentivo federal ${ }^{8}$

- Doações ou patrocínios de pessoas jurídicas, via lei de incentivo estadual

- Doações ou patrocínios de pessoas jurídicas, via lei de incentivo municipal

- Doação de fundações privadas ou públicas

- Verbas diretas dispensadas por empresas privadas ou públicas

- Verbas diretas dispensadas por pessoas físicas

- Editais públicos

- Editais de empresas privadas

- Igrejas, entre outros.

Pela minha experiência prática acumulada e pela minha experiência atual em captar recursos para projetos socioculturais percebi, portanto, que os empreendimentos podem ter grandes desafios em captar e obter recursos financeiros por também não terem ou não saberem iniciar, desenvolver ou gerir os principais fatores e processos internos elencados acima.

Além disso, há vários fatores externos, não controláveis pelas associações que não serão considerados neste trabalho, mas que contribuem para estes desafios e que poderão aparecer ao

\footnotetext{
${ }^{7}$ Segundo Lei no 8313 , de 1991, a doação é toda transferência de numerário sem finalidade promocional, enquanto patrocínio tem tal finalidade. Os benefícios fiscais podem variar de acordo com a modalidade de transferência de numerário e de tipo de projeto incentivado.

${ }^{8}$ Ainda, segundo Lei n ${ }^{\circ} 8313$, de 1991, a doação é toda transferência de numerário sem finalidade promocional, enquanto patrocínio tem tal finalidade. Os benefícios fiscais podem variar de acordo com a modalidade de transferência de numerário e de tipo de projeto incentivado
} 
longo da coleta e análise de dados. Exemplo de um fator não controlável pelos empreendimentos: os dez maiores projetos culturais, em termos de volume de captação de recursos no ano de 2015, via lei de incentivo federal, a conhecida Lei Rouanet, foram grandes produtores de musicais, peças teatrais, instituições de renome, entre outros, como mostra o quadro abaixo:

\begin{tabular}{|r|c|}
\hline \multicolumn{1}{|c|}{ Nome do Produtor } & Captado (milhões R\$) \\
\hline Aventura Entretenimento Ltda. & $\mathrm{R} \$ 21.712 .526,10$ \\
\hline Instituto Tomie Ohtake & $\mathrm{R} \$ 19.733 .528,17$ \\
\hline Instituto Itaú Cultural & $\mathrm{R} \$ 17.724 .344,00$ \\
\hline Tuseu de Arte de São Paulo Assis Chateaubriand & $14.730 .000,00$ \\
\hline Fundação Bienal de São Paulo & $\mathrm{R} \$ 13.270 .450,00$ \\
\hline EXPOMUS - Exposições Museus Projetos Culturais Ltda. & $\mathrm{R} \$ 12.286 .000,00$ \\
\hline Fundação Orquestra Sinfônica Brasileira & $\mathrm{R} \$ 10.799 .780,80$ \\
\hline D+3 Produções Artísticas Ltda & $\mathrm{R} \$ 10.719 .440,00$ \\
\hline Instituto Cultural Inhotim & $\mathrm{R} \$ 10.592 .266,65$ \\
\hline Total Produtores & $\mathbf{R} \$ \mathbf{1 4 5 . 0 3 3 . 3 3 5 , 7 2}$ \\
\hline Total Rouanet & $\mathrm{R} \$ 1.213 .706 .685,81$ \\
\hline
\end{tabular}

Quadro 1 - 10 maiores produtores por volume captado na Lei Rouanet 2015

(Quadro Elaborado pela Autora)

\subsection{Problemática observada e questão de pesquisa}

Do relato proposto anteriormente, é possível analisar e aprofundar a problemática de captação de recursos para empreendimentos socioculturais compreendendo como estes empreendimentos captam seus recursos, utilizando-se da aplicabilidade de todos os fatores e processos internos, nomeados acima. Mais especificamente aos fatores e processos internos ligados direta e estritamente à captação de recursos tais como: as fontes de captação, a estrutura organizacional dedicada à captação e as estratégias de captação do empreendimento. Para tanto, o presente trabalho visa responder à seguinte questão de pesquisa:

Como é a captação de recursos dos empreendimentos socioculturais, sob a ótica da estrutura, estratégias e fontes de captação?

Podendo, com a resposta à esta pergunta, contribuir na construção de um panorama qualitativo da captação de recursos para empreendimentos socioculturais e produzir conhecimento aplicável para a sustentabilidade destes.

Importante salientar que os empreendimentos socioculturais estudados e escolhidos neste trabalho serão, de acordo com sua natureza jurídica, empresas, bem como associações 
sem fins lucrativos, contanto que sejam iniciativas que utilizam a cultura e a arte como ferramentas de transformação social, objetivando o acesso à cultura artística, bem como a formação educacional, por via das mesmas, de indivíduos que não poderiam vivenciá-las devido às suas condições sociodemográficas, socioeconômicas e/ou físico-intelectuais.

Vale ressaltar que o número de empreendimentos socioculturais no Brasil não é fácil de ser mensurado, pois há pouco levantamento preciso a respeito. O que há são dados levantados do número de projetos culturais, que receberam incentivo fiscal, via lei Rouanet, não necessariamente projetos socioculturais, tampouco quantas são as associações e empresas produtoras destes projetos.

Os empreendimentos socioculturais podem ser, de acordo com sua natureza jurídica, além associações, as empresas e as fundações privadas, contando que possuam entre seus CNAE's a atividade cultural. Segundo dados do Instituto Brasileiro de Geografia e Estatística, o IBGE $^{9}$, as Fundações Privadas e Associações Sem Fins Lucrativos no Brasil estão divididas em Habitação (292 entidades), Saúde (6.029 entidades), Cultura e Recreação (36.921 entidades), Educação e Pesquisa (17.664 entidades), Assistência Social (30.414 entidades), Religião (82.853 entidades), Associações Patronais e Profissionais (44.939 entidades). Meio Ambiente e Proteção Animal (2.242 entidades), Desenvolvimento e Defesa de Direitos (42.463 entidades), outras (26.875 entidades). Por aqui, percebe-se também a dificuldade de encontrarmos o número preciso de empreendimentos que represente este ecossistema, no Brasil. Considerando-se os dados do IBGE, poderia se ter, como resultado de estudo sobre a natureza jurídica de iniciativas socioculturais, a produção de um gráfico com as zonas de intersecção entre vários agentes citados acima, tais como Fundações e Associações, Cultura e Recreação e Assistência Social, Educação e Pesquisa, pois, por experiência prática, a autora do trabalho conhece tipos de empreendimentos como estes realizando projetos socioculturais.

Para dificultar ainda mais a busca do número exato de empreendimentos desta natureza, segundo dados do Serviço Brasileiro de Apoio às Micro e Pequenas Empresas - SEBRAE ${ }^{10}$, as micro e pequenas empresas estão divididas em setor da indústria, comércio, serviços e agroindústria. As empresas de cultura estão no setor de serviço e em serviço, entra-se desde empresas de consultoria as produtoras culturais.

\footnotetext{
${ }^{9}$ Disponível em: http://ftp.ibge.gov.br/Fundacoes_Privadas_e_Associacoes/2010/fasfil.pdf. Acesso em: 3 de maio de 2016.

${ }^{10}$ Disponível em: http://www.sebrae.com.br/sites/PortalSebrae/ufs/mt/noticias/micro-e-pequenas-empresasgeram-27-do-pib-do-brasil,ad0fc70646467410VgnVCM2000003c74010aRCRD. Acesso em: 3 de maio de 2016.
} 
Um fato importante, é que para as leis de incentivo, a condição sine qua non para produção cultural é que esta possua Classificação de Atividade Econômica vinculada à cultura, desde Artes Visuais à Conservação de Patrimônio, conforme lista abaixo, contida na legislação Lei $n^{0}$ 12.268, de 20 de fevereiro de 2006 do Programa de Ação Cultural do Estado de São Paulo, onde projetos culturais podem estar em vinte e uma categorias, chamadas de atividades culturais independentes:

I Artes plásticas, visuais e design;

II Bibliotecas, arquivos e centros culturais;

III Cinema;

IV Circo;

V Cultura popular;

VI Dança;

VII Eventos carnavalescos e escolas de samba;

VIII Hip-hop;

IX Literatura;

X Museu;

XI Música;

XII Ópera;

XIII Patrimônio histórico e artístico;

XIV Pesquisa e documentação;

XV Teatro;

XVI Vídeo;

XVII Bolsas de estudo para cursos de caráter cultural ou artístico, ministrados em instituições nacionais ou internacionais sem fins lucrativos;

XVIII Programas de rádio e de televisão com finalidades cultural, social e de prestação de serviços à comunidade;

XIX Projetos especiais - primeiras obras, experimentações, pesquisas, publicações, cursos, viagens, resgate de modos tradicionais de produção, desenvolvimento de novas tecnologias para as artes e para a cultura e preservação da diversidade cultural;

XX Restauração e conservação de bens protegidos por órgão oficial de preservação;

XXI Recuperação, construção e manutenção de espaços de circulação da produção cultural no Estado. 


\subsection{Objetivos}

\subsubsection{Objetivo Geral}

O objetivo geral deste estudo é analisar como os empreendimentos socioculturais captam recursos sob três aspectos: estratégia, estrutura e fontes de captação.

\subsubsection{Objetivos Específicos}

Partindo do exame das experiências empíricas dos empreendimentos analisados e das bases teóricas aqui propostas, este projeto tem como objetivos específicos:

- Investigar se as iniciativas culturais dos respectivos empreendimentos são socioculturais

- Identificar quais são as estratégias de captação de recursos dos empreendimentos.

- Identificar quais são as fontes de captação de recursos dos empreendimentos.

- Identificar se a estrutura de captação dos empreendimentos é interna, terceirizada ou mista. 


\section{REFERENCIAL TEÓRICO}

Este trabalho objetiva analisar como os empreendimentos socioculturais captam recursos, sob à luz das experiências praticadas por eles. Estas experiências cotejadas ao referencial teórico que exporemos, nortearão as coletas e análises de dados, os resultados, as limitações e conclusões desta pesquisa.

O referencial teórico também contribuirá como importante fonte de dados para a elaboração das perguntas a serem feitas, através das entrevistas. Além das referências teóricas principais citadas aqui, como o eixo para o trabalho, haverá outras referências, como se pode conferir nas referências bibliográficas deste trabalho, complementares para a base do projeto, são referências vinculadas à metodologia de pesquisa e a planejamento estratégico, principalmente.

Assim estabelecido, o referencial teórico, eixo fundamental deste trabalho, trará definições:

\subsection{Da Cultura;}

2.2 Do Empreendedorismo Social: importante destacar que a literatura administrativa sobre empreendedorismo social vem se desenvolvendo há menos de 20 anos (FISCHER, 2011), e tem maior foco no setor social, na prática do empreender com escopo social, sem evocar especificamente a esfera cultural como força motriz;

\subsection{Do Empreendedorismo Cultural;}

2.4 Da Captação de Recursos: sendo utilizada a literatura para projetos sociais como paralela à prática de captação de recursos para projetos socioculturais, devido à literatura apresentar escassez quanto ao tema;

2.5 Das Leis de Incentivo: por estas serem fontes de recurso de captação ditas como as principais fontes de fomento da Cultura, no Brasil, como referido na introdução deste trabalho. 


\subsection{Da Cultura}

A Cultura, pelas vias de interpretação oficial da Unesco ${ }^{11}$, é o conjunto de traços distintivos espirituais e materiais, intelectuais e afetivos que caracterizam uma sociedade ou grupo social. Inclui, além das artes e da literatura, as formas de vida, as maneiras de se viver em sociedade, os sistemas de valores, as tradições e as crenças (BRANT, 2005, p.84).

Segundo Brant (2005), à cultura e seus representantes, isto é, os atores que vivem dentro da cultura, aqueles que a promovem, a reproduzem, a protegem ou a inovam, devemos dar-lhes uma voz para defender-se, pois a cultura é por essência a locomotiva que deve guiar as ações humanas.

Conforme Carrasso (2012), a cultura é indefinível, pois pela incerteza que pesa sobre sua definição permite todas as confusões, tanto quanto autoriza todas as concessões, já a arte é a ação artística, a ação do homem, o produzir materialmente. A maneira de pensar, de viver, de comer, de falar, de se vestir, de estar no mundo: é nossa cultura no sentido etimológico do termo.

Neste estudo, cuidaremos das manifestações artísticas que possibilitam produzir ações como a música, dança, literatura, entendendo que estas constituem e constroem a cultura. Por sua vez, a criatividade se configura genuinamente também como uma "ação", uma "atitude" do gênero humano que produz algo de novo, sendo entendida ainda como a capacidade de conectar o mundo das coisas e o mundo das ideias a fim de propor elementos inovadores em resposta a um determinado contexto. Nisso, cultura e criatividade estão estreitamente conectadas, pois, o elemento cultural nutre o comportamento criativo para agir em direção ao diferente, ao inovador. O elemento criativo, por sua vez, deriva do substrato cultural porque é a partir dos elementos simbólicos, formadores de uma cultura, que o indivíduo traz para si os estímulos que o movem a imaginar, intuir e, portanto, criar, novas ideias, novos empreendimentos, novos processos (CSIKSZENTMIHALYI, 1996)

Howkins (2001) afirma que há dois tipos de criatividade: o que se relaciona com a realização das pessoas como indivíduos e o que gera um produto, sendo o primeiro tipo uma característica universal da humanidade encontrado em todas as sociedades e culturas. $\mathrm{O}$ segundo tipo é mais forte nas sociedades industriais que colocam um valor mais alto na

\footnotetext{
${ }^{11}$ Disponível em: http://www.unesco.org/new/es/culture/. Acesso em: 03 de maio de 2016.
} 
novidade, na ciência e na inovação tecnológica, bem como sobre os direitos de propriedade intelectual. Há, no entanto, outras muitas definições de criatividade. No campo da psicologia, por exemplo, em complemento e contraponto à afirmação de Howkins, a criatividade individual foi mais estudada, não havendo acordo quanto ao fato de a criatividade ser um atributo de pessoas ou um processo pelo qual as ideias originais são geradas.

Cultura e criatividade podem ser lidas como elementos que em seu conjunto geram inovação e, por certo, valor econômico. A criatividade liga-se à arte enquanto processo de idealização e concepção de um patrimônio intangível a cada forma de expressão, seja uma poesia, um romance, uma pintura, uma escultura, uma fotografia, ou uma intervenção performática. Mas, é importante pontuar que o elemento criativo não está exilado ao contexto artístico. Nesse sentido, vale lembrar o vasto estudo de Barlach (2009), no qual foram exploradas as principais fontes da literatura que se ocupam simultaneamente da criatividade e do empreendedorismo. A tal propósito, Barlach identifica no senso comum a ideia do poder criativo enquanto "bem" prevalecente da classe artística. Disso, abrindo-se para a perspectiva da criatividade como bem intrínseco ao humano manifestado em qualquer referencial social, é possível conceber o ser criativo exprimindo-se e atuando cotidianamente seja em contexto artístico, científico, organizacional e, seguramente, institucional.

Segundo o documento intitulado de Panorama da Economia Criativa no Brasil, concebido pelo Instituto Pesquisa Econômica Aplicada (IPEA), em 2013, as características de criatividade podem ser articuladas em três grandes áreas:

a) A criatividade artística, que envolve a imaginação e a capacidade de gerar ideias originais e novas maneiras de interpretar o mundo, expressa em texto, som e imagem.

b) A criatividade científica, que envolve curiosidade e uma vontade de experimentar e fazer novas conexões em resolução de problemas.

c) A criatividade econômica, que é um processo dinâmico conducente à inovação em tecnologia, práticas de negócios, marketing, e está intimamente ligada à obtenção de vantagens competitivas na economia. (DE OLIVEIRA, 2013, pg. 9).

Para fins deste estudo, consideraremos os empreendimentos que compõem a cultura brasileira, a partir da utilização de sua criatividade artística para a produção de manifestações artísticas tais como música, teatro, cinema, fotografia. 


\subsection{Do Empreendedorismo Social}

De acordo com Yunus (2000), empreendimentos sociais são as organizações que se concentram em oferecer um benefício social - em vez de maximizar os lucros para os proprietários - e pertencem a investidores que objetivam benefícios sociais, tais como redução da pobreza, saúde para indivíduos em vulnerabilidade econômica, promoção da inclusão social.

Já o austríaco Drucker (1985), descreve os empreendedores como atores sociais que identificam, reagem e exploram mudanças como oportunidades para a geração de valor, sendo agentes de transformação social. Segundo Fischer (2011), o conceito empregado por Drucker passa a ser transportado da esfera das atividades econômicas e empresariais para a esfera das atividades sociais, dando margem ao surgimento da expressão Empreendedorismo Social, que avança no sentido de conceber estas organizações como aquelas para as quais a missão social é central e explícita e a riqueza gerada não é um fim em si mesma, mas um meio para atingir finalidades sociais. E, ainda, destaca:

No Brasil, as primeiras publicações sobre o empreendedorismo social, na década de 1990, se restringiram a artigos em revistas, nos jornais, na internet e em algumas publicações da Ashoka ${ }^{12}$ do Brasil. A partir dos anos 2000, começaram a surgir estudos, com maior densidade teórica, que procuravam sistematizar a ocorrência do empreendedorismo social no país. Mais recentemente, verifica-se uma tendência nos estudos nacionais em preencher lacunas e estabelecer o diálogo entre abordagens centradas no empreendedor e aquelas onde sobressaem o empreendimento e seu contexto. Este percurso conceitual e teórico demonstra que o tema do empreendedorismo social - tanto na produção acadêmica strictu sensu, como naquela oriunda da análise de vivências empreendedoras, como as histórias de vida e os estudos de caso - necessita ainda de amadurecimento da capacidade analítica e esforço de consenso entre os estudiosos. (FISCHER, 2011, p.196-198)

De fato, o empreendimento social, em última instância, se inicia com a percepção de um problema social e a busca de soluções - inovadoras ou conhecidas - seguindo-se uma fase de solução e sua implementação junto ao público beneficiário ou comunidades (ASHOKA,

12 Ashoka é uma organização mundial, sem fins lucrativos, criada em 1981 pelo norte-americano Bill Drayton, e presente em 60 países. Está no Brasil desde 1986 e é considerada pioneira na criação do conceito e na caracterização do empreendedorismo social. Disponível em: www.ashoka.org.br. Acesso 02 de dezembro 2017. 
2001). Recentemente o emprego do termo Negócio de Impacto, vêm sendo vinculado aqui no Brasil também aos empreendimentos sociais.

O Instituto de Cidadania Empresarial (ICE) está continuamente ganhando força de atuação e relevância no campo social formando grupos de pessoas e instituições para fomentar soluções inovadoras que geram impacto social positivo, duradouro e de grande alcance para a população de baixa renda, contribuindo para a redução da pobreza e da desigualdade social. O ICE nasceu em 1999 com o objetivo de reunir empresários e investidores em torno de inovações sociais que pudessem alavancar seu investimento pessoal e filantrópico, de suas fundações e seu investimento corporativo.

Nesse contexto, Negócio de Impacto é definido sinteticamente no próprio site do ICE como:

Os negócios de impacto podem assumir diferentes formatos legais: associação, fundações, cooperativas ou empresas. Há quatro princípios que os diferenciam, independentemente da constituição jurídica da organização:

- Têm um propósito de gerar impacto socioambiental positivo explícito na sua missão

- Conhecem, mensuram e avaliam o seu impacto periodicamente

- Têm uma lógica econômica que permite gerar receita própria

- Possuem uma governança que leva em consideração os interesses de investidores, clientes e a comunidade. (Disponível em http://ice.org.br/. Acesso em: 23 de novembro de 2017)

Podendo também ser traduzido o conceito, através da figura abaixo: 


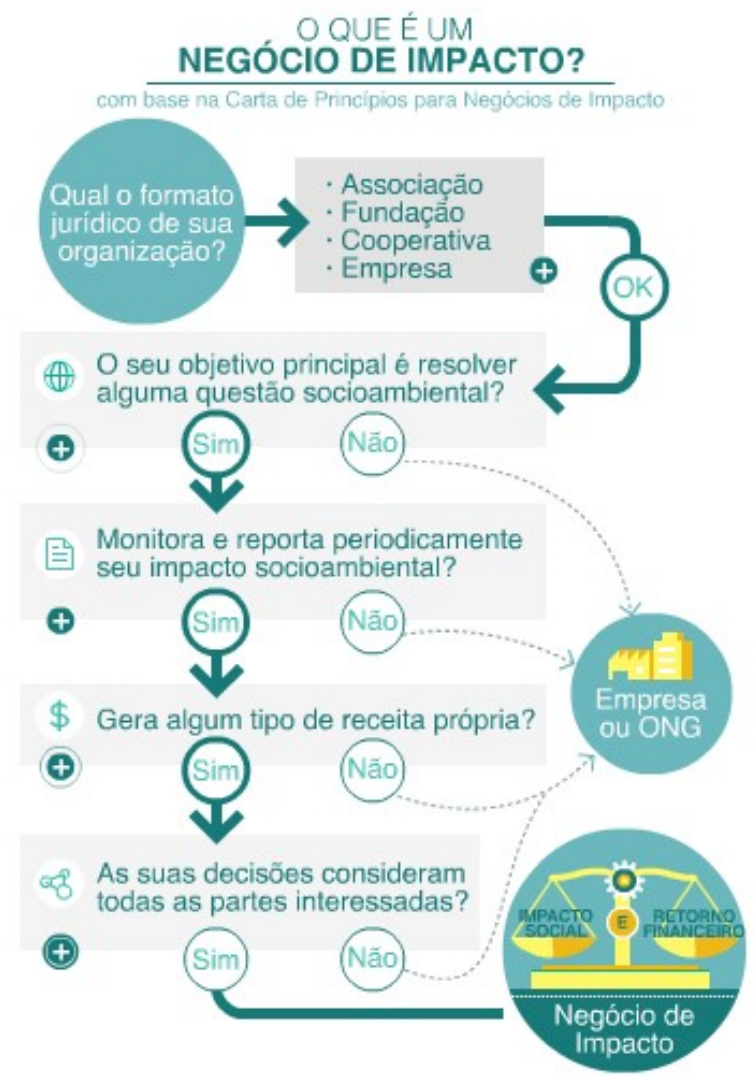

Figura 1- O que é um Negócio de Impacto.

(Fonte: http://ice.org.br/)

Para os fins aqui propostos, utilizaremos o conceito de empreendimento social empregado por Yunnus, por considerarmos que as manifestações artísticas, definidas previamente, são benefícios sociais oferecidos à população que não pode ter acesso a elas seja por questões socioeconômicas, sócio - geográficas ou físico-intelectuais. Importante salientar também que o ICE considera o acesso à cultura como uma das soluções a serem oferecidas por negócios de impacto, mas, no Brasil, não há ainda aprofundamento de estudos com foco no recorte cultural especificamente.

\subsection{Do Empreendedorismo Cultural}

No âmbito do empreendedorismo cultural, a literatura brasileira tem maior foco em gestão cultural do que na definição e na discussão, propriamente dita, do que se entende por 
“empreender" cultural. ${ }^{13}$ Podemos adotar, para os fins aqui propostos, a união entre empreender e cultura, primando para que o segundo termo tenha vínculo direto com a entrega para a sociedade de um bem cultural, sendo este uma manifestação artística, tal como peça de teatro, música, literatura, cinema.

Vale ressaltar a importância do empreendedor cultural na produção dos bens culturais. Muitas vezes, este não se atém à busca de resultados financeiros imediatos, mas sobretudo à satisfação da entrega do que produz e/ou à entrega do que produz a quem não tem acesso a este, sendo, sob esta última ótica, considerado um empreendimento sociocultural. Quanto a isso, Leonardo Brant, em seu livro Mercado Cultural, afirma:

O investimento, geralmente realizado nos grandes espetáculos ganha força se for atrelado a questões sociais (...). Numa realidade como a do Brasil, é fundamental inserir ou identificar a produção cultural com causas comunitárias, não apenas com processo de construção da marca cultural e sua patrocinadora, mas também como parte do processo de sensibilização e formação de novos públicos consumidores de cultura. (BRANT, 2002, p. 35)

Esta afirmação nos conduz a refletir sobre a relação entre a causa sociocultural e a necessidade de sobrevivência financeira de um bem cultural. Cabe analisar em que medida uma influi na outra ou uma determina a outra, no contexto de sustentabilidade brasileira para empreendimentos que produzem cultura e a disponibilizam a quem não pode pagar por ela, como é o caso de todas as organizações entrevistas, e tantas outras no cenário cultural artístico brasileiro.

Ao analisarmos o que é um empreendimento cultural, sob a ótica do que se produz, poderíamos vincular a produção cultural como pertencente ao setor da Economia Criativa.

O relatório Economia Criativa e Cultura: Um Guia Introdutório, com autoria de John Newbigin (2010), discorre a respeito do recente surgimento do termo Economia Criativa, datado de menos de quinze anos à época da escrita do presente trabalho. Este mesmo relatório aponta que o estado pioneiro em definir e estimular discussões e formações de órgãos que fomentem a Economia Criativa foi o Reino Unido e que este, juntamente com a UNCTAD ${ }^{14}$,

\footnotetext{
${ }^{13}$ A definição do termo empreendedorismo cultural comporta inúmeras abordagens seja pelos caminhos da cultura no empreender quanto do empreender na cultura. Não obstante, na produção acadêmica, a integração destas abordagens ainda é pouco difusa (MACHADO, 2013). Dentre os estudos mais relevantes para o tema, podemos citar alguns nomes como BRANT, 2002; ELLMEIER, 2003; SPLLING, 2006.

${ }^{14}$ Refere-se à Conferência das Nações Unidas sobre Comércio e Desenvolvimento, criada em 1964, em Genebra, na Suíça, no contexto das discussões de liberalização do comércio do GATT, é o órgão da Assembleia Geral da Organização das Nações Unidas que busca promover a integração dos países em desenvolvimento na economia.
} 
promoveu a definição do termo como referente àquelas atividades que têm sua origem na criatividade, na habilidade e no talento individual, potencializando a criação de empregos e riqueza, através da exploração da propriedade intelectual.

Segundo as Nações Unidas, as atividades do setor estão baseadas no conhecimento e produzem bens tangíveis e intangíveis, intelectuais e artísticos, com conteúdo criativo e valor econômico. Já o conceito teórico de economia criativa é atribuído à Howkins (2001) e este sustenta a ideia de que a economia criativa se assenta sobre a relação entre a criatividade, o simbólico e a economia.

Para fins deste trabalho, poderíamos focalizar as definições empregadas por instituições brasileiras, mesmo sabendo que estas sofreram influências diretas das definições advindas da matriz da terminologia, no Reino Unido. A título informativo e comparativo, no entanto, vale lembrar que a classificação adotada pelo Departamento de Cultura, Mídia e Esporte do Reino Unido, enquadra os setores da Economia Criativa em treze áreas:

- Artesanato

- $\quad$ Arquitetura

- Artes Cênicas

- $\quad$ Artes e Antiguidades

- Cinema

- Designer

- Editorial

- $\quad$ Música

- Moda

- $\quad$ Publicidade

- Software

- Software interativo de lazer (vídeo games)

- Televisão e Rádio

A partir daí, percebe-se a influência direta nas definições adotadas tanto pelo SEBRAE quanto pelo Ministério da Cultura, no Brasil quando ambos se referem a empreendimentos culturais, no setor criativo. A Economia Criativa, segundo o SEBRAE, é um termo criado para nomear modelos de negócio ou gestão que se originam em atividades, produtos ou serviços desenvolvidos a partir do conhecimento, criatividade ou capital intelectual de indivíduos com vistas à geração de trabalho e renda. Diferentemente da economia tradicional, de manufatura, 
agricultura e comércio, a economia criativa, essencialmente, foca no potencial individual ou coletivo para produzir bens e serviços criativos. ${ }^{15}$

No Brasil, em 2011, foi criada a Secretaria da Economia Criativa, submetida ao Ministério da Cultura no governo federal, percebendo-se aqui a relação direta entre cultura e economia criativa. Também o SEBRAE tem uma área em seu site dedicada ao chamado, segundo ele, segmento da economia criativa.

Ao lermos o plano de ação da Secretaria da Economia Criativa ${ }^{16} \operatorname{logo}$ nos deparamos com a definição adotada por tal para nomearmos, no Brasil, o setor criativo:

(...) os setores criativos são aqueles cujas atividades produtivas têm como processo principal um ato criativo gerador de um produto, bem ou serviço, cuja dimensão simbólica é determinante do seu valor, resultando em produção de riqueza cultural, econômica e social. (...) Na primeira etapa do nosso Plano, definimos Economia Criativa partindo das dinâmicas culturais, sociais e econômicas construídas a partir do ciclo de criação, produção, distribuição/circulação/difusão e consumo/ fruição de bens e serviços oriundos dos setores criativos, caracterizados pela prevalência de sua dimensão simbólica. (Plano da Secretaria da Economia Criativa, 2012, pg. 24).

Pela definição da Secretaria da Economia Criativa, os seis empreendimentos socioculturais, analisados neste trabalho, poderiam estar enquadrados em três dos cinco campos definidos na figura abaixo - nos campos das expressões culturais, das artes do espetáculo e do audiovisual, devido aos setores que pertencem, respectivamente - fotografia, teatro e cinema:

${ }^{15}$ Disponível em https://www.sebrae.com.br/sites/PortalSebrae/segmentos/economia_criativa. Acesso em: 21 de junho de 2017.

${ }^{16}$ Disponível em http://cultura.gov.br/secretaria-da-economia-criativa-sec. Acesso em: 21 de junho de 2017. 


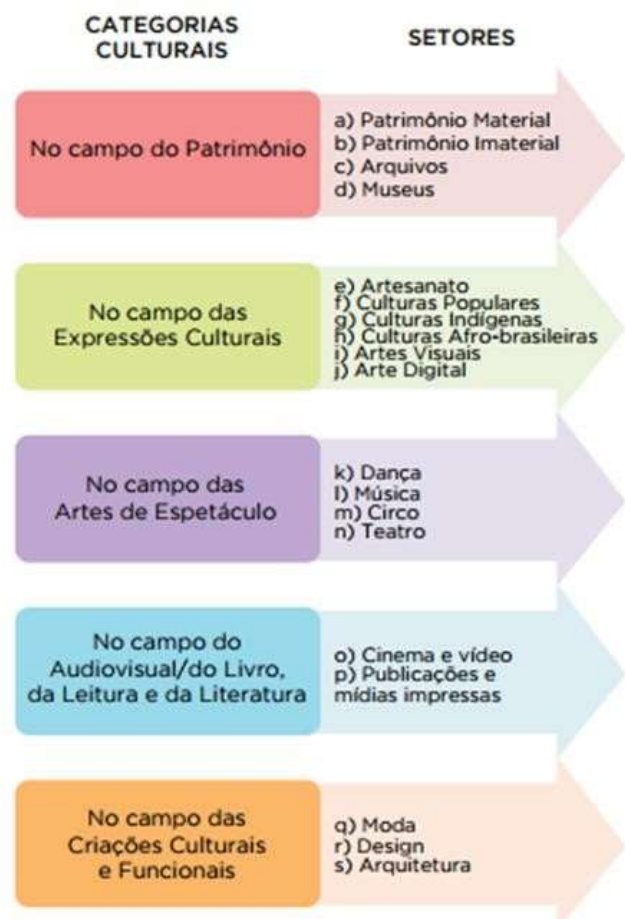

Figura 2 - Escopo dos Setores Criativos. Fonte: Ministério da Cultura, 2011.

Por outra perspectiva, para o SEBRAE, o segmento da Economia Criativa é classificado nas áreas de:

\section{Arquitetura}

- $\quad$ Artes visuais

- $\quad$ Cinema

- Televisão

- $\quad$ Publicidade e outras mídias

- Design

- Games

- $\quad$ Editoração

- $\quad$ Música

- Comunicação

Ainda para a instituição, os segmentos criativos podem ser alinhados de acordo com suas afinidades setoriais em quatro grandes áreas:

- $\quad$ Consumo (design, arquitetura, moda e publicidade)

- Mídias (editorial e audiovisual)

- Cultura (patrimônio e artes, música, artes cênicas e expressões culturais)

- Tecnologia (P\&D, biotecnologia e TIC) 
Por fim, faz-se importante delimitar, após todas as definições acima para Cultura, Empreendedorismo Social e Empreendedorismo Cultural, que quando nos referirmos a empreendimentos socioculturais, ao longo deste trabalho, estaremos trazendo uma referência teórica às iniciativas que utilizam as manifestações artísticas - fotografia, cinema, teatro - como benefício social à população que não pode ter acesso a elas seja por questões socioeconômicas, sócio geográficas ou físico-intelectuais.

\subsection{Da Captação de Recursos}

Segundo Cruz e Estraviz (2000), as organizações da sociedade civil diferem muito em suas missões, suas realidades e necessidades, o que pressupõe formas de captação de recursos distintas, com compatibilidade de interesses entre a sua missão e os seus doadores. Independente destas diferenças, formularam um estudo, pretendendo contribuir com ideias e técnicas e, talvez, inspiração na captação de recursos para as organizações sem fins lucrativos, no geral.

Portanto, as definições dos autores não foram focadas em empreendimentos socioculturais, mas podem ser utilizadas como norte, dado que a literatura para tal ainda é escassa. Cruz e Estraviz (2000), elencam como requisitos internos e externos, os principais pontos para a organização social captar recursos, tais como:

Requisitos Internos:

- Missão e causa, pois esta é sem dúvida uma das razões que mais motivam pessoas a trabalharem ou contribuírem como ela;

- Boa gestão da organização e dos recursos doados;

- Toda a organização tem que estar envolvida com a captação, mas é importante ter um responsável por ela;

- Sustentabilidade buscando envolver vários financiadores, governo, empresas, fundações, sócios, além de geração de recursos próprios.

Requisitos Externos:

- Transparência como fundamental e como sinônimo de prestação de contas à comunidade;

A comunicação com a comunidade faz parte da defesa da causa, não podendo considerar os apoiadores como seres passivos, que simplesmente recebem informações da instituição;

- $\quad$ Parcerias com compatibilidade de interesses. 
Os autores também citam a importância de se manter um banco de dados com potenciais fontes de recursos e de se realizar relacionamento, depois que uma doação ou investimento direto foram realizados.

Ainda para Cruz e Estraviz (2000), as possíveis fontes de recursos, também nomeadas pelos autores como fontes de financiamento são:

- $\quad$ Indivíduos que podem ser acionados por ações de telemarketing ou mala direta

- $\quad$ Empresas

- Fundações nacionais e internacionais e Agências Internacionais

- $\quad$ Igrejas

- Recursos Públicos Governamentais

- $\quad$ Eventos

- $\quad$ Projeção de Geração de Renda

- Outras fontes de recursos

Na perspectiva aqui trabalhada, consideramos que eventos e projeção de geração de renda são meios, ferramentas estratégicas para obtenção de recursos e não são fontes de captação. As fontes de captação representam os interessados em dar, doar ou investir recursos no empreendimento.

Segundo Reis (2006), o setor cultural pode ser financiado de variadas fontes entre públicas (federal, estadual, municipal) e privadas (pessoas físicas, empresas, fundações, organizações sem fins lucrativos). E a compreensão do entrelaçamento entre as esferas pública e privada e a forma como se complementam é primordial para formar o quadro do financiamento da cultura no Brasil. A autora destaca:

- Financiamentos públicos diretos como subsídios às instituições culturais; subsídios a artistas e os próprios fundos de cultura.

Financiamentos públicos indiretos à iniciativa privada, as chamadas leis de incentivo federais, estaduais e municipais que são atualmente as maiores impulsionadoras de participação da iniciativa privada no setor cultural.

- Financiamentos públicos indiretos quanto à discriminação de preços e fornecimentos de cheques culturais;

- Financiamentos públicos indiretos quanto à privilégios fiscais a produtos, serviços e pessoas culturais;

- $\quad$ Financiamento privado sem contrapartidas públicas; entre outras formas.

Vale ressaltar, que a autora não dá foco a projetos socioculturais e sim à investimento e fontes de financiamento para a cultura em sua totalidade. 
No Brasil, há recentemente uma plataforma online, nomeada "Captamos", cujo foco principal é a produção de conhecimento, através de artigos, cursos e trocas entre pesquisadores, professores e profissionais da área de captação de recursos para fortalecer causas, organizações da sociedade civil e, principalmente, o seu financiamento. A Captamos nasceu como resultado de um encontro realizado em 2015, promovido pelo Instituto Arapyaú ${ }^{17}$, e cujo objetivo principal era definir formas e caminhos para fortalecer os campos da captação de recursos e da cultura de doação no Brasil.

Atualmente, a Captamos é gerenciada pela Associação Brasileira de Captadores de Recursos - ABCR, e liderada por um Conselho de Administração próprio, composto de profissionais de diversas áreas e origens.

Importante salientar, que assim como Cruz e Estraviz (2000), todos os conceitos difundidos na plataforma são para as iniciativas sociais na totalidade, não especificamente para o setor sociocultural.

Esta plataforma, nos apresenta o conceito de captação de recursos da seguinte forma:

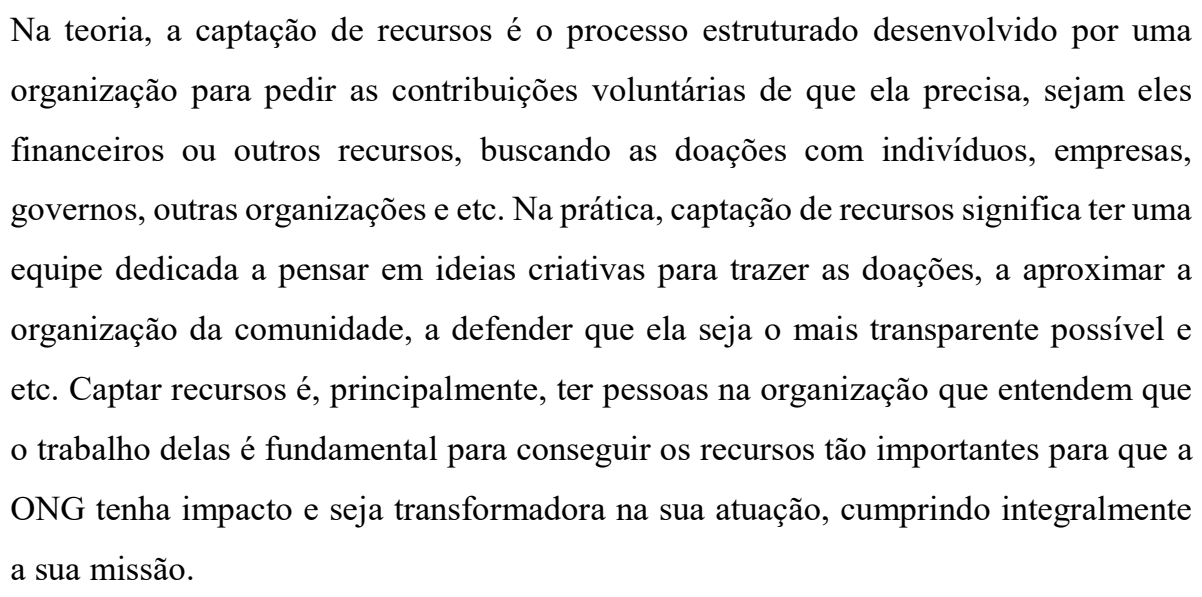
(Disponível em: http://captamos.org.br/news/1185/o-que-captao-de-recursos. Acesso em: 23 janeiro de 2018)

Além disto, a plataforma define a importância de se ter um plano de captação - a ferramenta para garantir que a organização faça a escolha certa: o que pedir, para quem pedir e como pedir definido - em cinco principais passos:

1) Conhecer a sua associação, desenhando uma matriz de forças, fraquezas, oportunidades e ameaças.

17 Arapyaú é uma associação sem fins lucrativos que está empenhada na promoção do desenvolvimento sustentável, segundo definição extraída de seu site institucional, disponível em: http://www.arapyau.org.br/quemsomos.html. Acesso em: 16 de dezembro de 2017) 
2) Elaborar um Orçamento Anual.

3) Identificar as Fontes de Captação.

4) Traçar as Estratégias e Técnicas de Capitação de Recursos

5) Construir o Plano para garantir a sustentação da organização.

A mesma plataforma reforça que há inúmeras fontes de captação de recursos disponíveis para organizações da sociedade civil (OSC's) e, consequentemente, inúmeras estratégias de captação de recursos podem ser planejadas e executadas, afim de atingirem estas variadas fontes, de forma assertiva, objetivando o sucesso na obtenção de recursos. Abaixo, listaremos os grupos de fontes, que a Captamos considera, e mais adiante falaremos dos exemplos de estratégias sugeridas pela plataforma:

Iniciativa privada, que compreende empresas, indivíduos (pessoas físicas) e institutos corporativos, muitas vezes assemelhados aos departamentos de responsabilidade social das empresas e às fundações empresariais;

- Fundações, que podem ser: familiares, empresariais, independentes, comunitárias ou mistas;

- $\quad$ Organizações religiosas;

- Fontes institucionais, incluindo: governos (internacionais, nacional/federal, estaduais e municipais), agências internacionais (bilaterais e multilaterais), organizações comunitárias, clubes de serviço e outras associações.

Abaixo, segue quadro apresentado na plataforma com os valores investidos, divididos por fonte de captação:

Valores aportados por fonte

\begin{tabular}{|c|c|c|c|}
\hline Fantes de Recursos & $\begin{array}{l}\text { Pesquisa } \\
\text { FGV (1) }\end{array}$ & $\begin{array}{c}\text { Outras } \\
\text { estimativas }\end{array}$ & Total \\
\hline Pcssoas físicas & - & $13(2)$ & 13 \\
\hline Gisverne Feteral & 3,4 & - & 3,4 \\
\hline Governes estaduats et minicipais & 14,2 & - & 14,2 \\
\hline Enpresas Gife (mem incentivos) 2014 & $2.5(5)$ & $\cdot$ & 2.5 \\
\hline Incentivos fiscais empresas & - & $2,5(3)$ & 2.5 \\
\hline Outras cupresas & - & $4,5(4)$ & 4.5 \\
\hline Internacional & 0,7 & - & 0,7 \\
\hline TOTAL. & 18,3 & 17,7 & 40,8 \\
\hline
\end{tabular}

Quadro 2 - Valores Aportados por fonte - Quadro elaborado em 2016 (Fonte: http://captamos.org.br/news/3053/fontes-para-mobilizao-de-recursos-4\#_ftn5) 
A plataforma enumera ainda várias possibilidades de estratégias de captação a serem praticadas por cada OSC's, tais como:

- Crowdfunding ${ }^{18}$

- Contrata celebridades para representarem a causa da organização e consequentemente atrair doações de pessoas físicas, principalmente;

- Apostarem no discurso e na atuação dos apoiadores de causas divididos entre investidores de grande, médio ou pequeno porte através das estratégias representadas na figura abaixo:

\begin{tabular}{|c|c|c|c|}
\hline Estratégia principal & Estratégia secundária & Táticas & Ferramentas / Canais \\
\hline \multirow{14}{*}{$\begin{array}{l}\text { 2) Apoiadores da } \\
\text { causa } \\
\text { (supporters) }\end{array}$} & \multirow{6}{*}{$\begin{array}{l}\text { 1. Grandes e médios } \\
\text { doadores (major donors) }\end{array}$} & a) Legados & \multirow{6}{*}{$\begin{array}{l}\text { rede, visitas pessoais, desenvolvimento de } \\
\text { conselhos, email e pesquisa, cotas, incentivos } \\
\text { fiscais, contar histórias, selo, websites, nome de } \\
\text { espaços }\end{array}$} \\
\hline & & b) Doaçāo em dobro (Matchfund) & \\
\hline & & $\begin{array}{l}\text { c) investidor anjo, love e seed money, } \\
\text { venture capital }\end{array}$ & \\
\hline & & $\begin{array}{l}\text { d) Com vinculo à organização ou a seus } \\
\text { gestores }\end{array}$ & \\
\hline & & Sem vinculo & \\
\hline & & e) Campanha capital & \\
\hline & \multirow{4}{*}{ 2. Pequenos doadores } & $\begin{array}{l}\text { f) Doação regular, recorrente } \\
\text { (membership-adote) }\end{array}$ & \multirow{3}{*}{$\begin{array}{l}\text { cara a cara, email, mala direta, clique e agende, } \\
\text { telemarketing, redes sociais, jogos, torpedo - SMS, contar } \\
\text { histórias, tijolo, voluntariado, embaixadores da causa, videos, } \\
\text { direct response - TV, comunicaçăo permanente, P2P }\end{array}$} \\
\hline & & g) Apadrinhamento (programa de & \\
\hline & & h) Solicitação - doação única - identificada & \\
\hline & & i) Solicitação - doação não identificada, & Arredondar, frente de caixa, MRC \\
\hline & \multirow{3}{*}{ 3. Parcerias } & i) Prestadores de serviços & \multirow{3}{*}{ visitas, pesquisa, contratos, penas alternativas } \\
\hline & & 1) Pesquisa / Nota fiscal (paulista) & \\
\hline & & m) Diretoria / voluntários & \\
\hline & 4. Catástrofes & n) Emoçăo e emergência & redes sociais, anúncios, SMS, vídeos \\
\hline
\end{tabular}

Quadro 3 - Estratégias por apoiadores de causa

(Fonte: http://captamos.org.br/news/4060/estratgia-2-apoiadores-de-causas-parte-33)

- Atuarem com a estratégia de geração de renda própria, através da produção de produtos ou serviços, que garantam geração de renda sem a necessidade de doações, tal como ilustrado abaixo:

${ }^{18}$ Segundo SEBRAE, por meio de plataformas colaborativas, muitas pessoas ou equipes já estão cadastrando seus projetos e conquistando o apoio de diversos colaboradores para a sua realização. Trata-se do chamado $\begin{array}{llllll}\text { crowdfunding, } & \text { ou } & \text { financiamento } & \text { coletivo. } & \text { (Disponível } & \mathrm{em}\end{array}$ http://www.sebrae.com.br/sites/PortalSebrae/artigos/entenda-o-que-ecrowdfunding,8a733374edc2f410VgnVCM1000004c00210aRCRD. Acesso em: 4 de abril de 2018) 


\begin{tabular}{|c|c|c|c|}
\hline Estratégia principal & Estratégia secundária & Táticas & Ferramentas / Canais \\
\hline \multirow{7}{*}{$\begin{array}{l}\text { 3) Geração de Renda } \\
\text { Própria (GRP) }\end{array}$} & \multirow{2}{*}{ 1. Venda de produtos } & $\begin{array}{l}\text { a) Micro doaçẫo-artedondar, NFP } \\
\text { b) Loja propria }\end{array}$ & \multirow{2}{*}{$\begin{array}{l}\text { Divulgação, anúncios, cartăo de crédito, } \\
\text { web sites de venda, estatuto ajustado }\end{array}$} \\
\hline & & c) Bazar / brinde / rifa / leilao / compre 1 e doe 1 & \\
\hline & 3. Licenciamento & e) Criar personagem & \multirow{2}{*}{$\begin{array}{l}\text { Rede, pesquisa e reuniâa, estatuto } \\
\text { ajustado }\end{array}$} \\
\hline & $\begin{array}{l}\text { 4. MRC-Marketing } \\
\text { relacionado a causas }\end{array}$ & f) Gestâ̄o de marcas e parcerlas (Branding) & \\
\hline & $\begin{array}{l}\text { 6. Captaçăo de produtos } \\
\text { (in kind) }\end{array}$ & $\begin{array}{l}\text { h) Rede/ Coleta / pré-compra/permuta / contra } \\
\text { partida / compre um - doe um }\end{array}$ & $\begin{array}{l}\text { Solicitaçăo, anunciar, sites de leilão, } \\
\text { caminhão, bens apreendidos }\end{array}$ \\
\hline & 7. Fundos patrimoniais & i) Gestāo e governança & Regulamentos especificos e estatuto \\
\hline & 8. Alugueis & i) Anûncios & Contrate \\
\hline
\end{tabular}

Quadro 4 - Estratégias por tipo de geração de renda

(Fonte: http://captamos.org.br/news/5818/estratgia-3-gerao-de-renda-prpria-grp-parte-33)

Assim como afirmou Cruz e Estraviz (2000) que há inúmeras organizações, com missões e realidades distintas, podemos observar que há inúmeras possibilidades de estratégias a serem planejadas e executadas por empreendimentos sociais, na prática; assim como também há inúmeras definições teóricas para a palavra estratégia como a arte de explorar condições e caminhos favoráveis com o fim de alcançar objetivos (dicionário Aurélio) até como sendo uma forma de pensar no futuro, integrada no processo decisório, com base em um procedimento formalizado e articulador de resultados (MINTZBERG, Henry; AHLSTRAND, B.; LAMPEL, J, 2010).

Ainda sobre fontes de recursos, sem a especificidade das fontes existentes para o setor cultural, há um mapeamento relevante, intitulado de Mapeamento dos Recursos Financeiros disponíveis no Campo Social do Brasil com o objetivo de identificar recursos potenciais para Finanças Sociais, feito em 2015, pela empresa Delloite, a pedido do Força Tarefa de Finanças Sociais ${ }^{19}$ com o objetivo de realizar um levantamento das fontes de recursos já existentes e disponíveis, mas que hoje não são direcionadas ao ecossistema de finanças sociais, ou o são parcialmente. Finanças Sociais, para o Força Tarefa, compreendem instrumentos financeiros, novos e existentes, que mobilizam capital para investimento em atividades com a intenção de produzir impacto social com sustentabilidade financeira, podendo ou não gerar retorno financeiro sobre o capital investido. O impacto deve ser passível de mensuração e analisado

\footnotetext{
${ }^{19}$ A Força Tarefa de Finanças Sociais (FTFS) é um movimento criado para identificar, conectar e apoiar organizações e temas estratégicos para o fortalecimento do campo das Finanças Sociais e dos Negócios de Impacto no Brasil. Em outubro de 2015, a FTFS lançou 15 recomendações para avançar o campo, com metas para 2020. Esse conteúdo foi construído a partir de referências globais e consulta a muitos atores envolvidos nessa agenda. (Disponível em: https://forcatarefafinancassociais.org.br/creca-da-forca-tarefa-brasileira-de-financas-sociais/. Acesso em: 4 de abril de 2018)
} 
periodicamente. Sob esta ótica podemos considerar que a maioria destas fontes mapeadas também são fontes passíveis de serem utilizadas como fontes de recursos para empreendimentos socioculturais.

As fontes na totalidade seguem citadas abaixo:

1) Governo Federal

2) Organismos nacionais de fomento, divididos tal como o quadro abaixo:

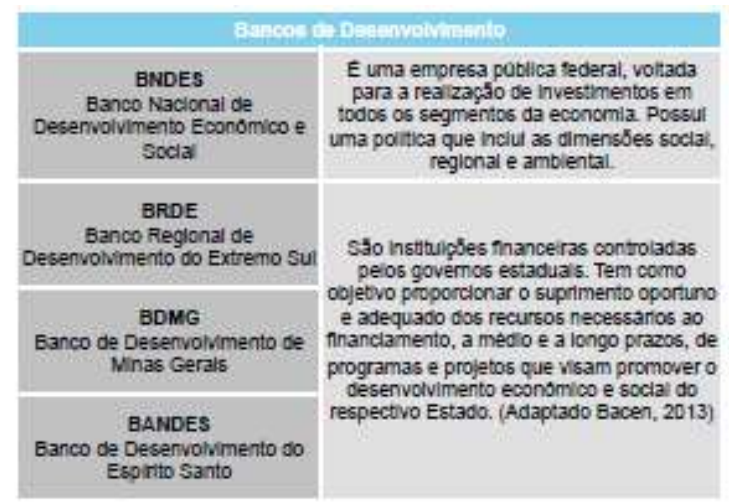

\begin{tabular}{|c|c|}
\hline \multicolumn{2}{|c|}{ Actensing ob tring in. } \\
\hline $\begin{array}{l}\text { BADESUL } \\
\text { Ag de fomento do RIO Grande do Sus }\end{array}$ & $\begin{array}{l}\text { AGN } \\
\text { Ag. de fomento do Ro Grande do Norte }\end{array}$ \\
\hline $\begin{array}{l}\text { Fomento Parana } \\
\text { Agencla de fornerto do Parana }\end{array}$ & $\begin{array}{c}\text { AGEFEPE } \\
\text { Ag. de fomentb do Pemamouco }\end{array}$ \\
\hline $\begin{array}{l}\text { Desenvivolve SP } \\
\text { Ag de Fomento de SP }\end{array}$ & $\begin{array}{l}\text { Desenvolve AL } \\
\text { Ag. de fomento de Alagoas }\end{array}$ \\
\hline $\begin{array}{l}\text { Desenbahila } \\
\text { Ag. de Fomento da Eahla }\end{array}$ & $\begin{array}{l}\text { MT Fomento } \\
\text { Ag de fomernto do Mato Grosso }\end{array}$ \\
\hline $\begin{array}{c}\text { BADESC } \\
\text { Ag de fomento de Santa Catarna }\end{array}$ & $\begin{array}{l}\text { Fomento Tocantins } \\
\text { Ag. de fomento de Tocantins }\end{array}$ \\
\hline $\begin{array}{l}\text { Agervo } \\
\text { Ag. de tomento do Fo de J J nelro }\end{array}$ & $\begin{array}{l}\text { Plaul Fomento } \\
\text { Ag. de fomentio de Plaul }\end{array}$ \\
\hline $\begin{array}{l}\text { AFEAM } \\
\text { Ag. de tomento do Amazonas }\end{array}$ & $\begin{array}{c}\text { FERR } \\
\text { Ag. de tomento de Rorama }\end{array}$ \\
\hline $\begin{array}{l}\text { Golse Fomento } \\
\text { Ag. de tomento de Golas }\end{array}$ & $\begin{array}{l}\text { AFAP } \\
\text { Ag de fomento do Amapa }\end{array}$ \\
\hline
\end{tabular}

Quadro 5 - Organismos nacionais de fomento. (Fonte: https://forcatarefafinancassociais.org.br//)

3) Organismos Multilaterais de Crédito

Principais Organismos Multilaterais de Crédito com os quais o Brasil mantém cooperação financeira (Fonte: Ministério do Planejamento, Orçamento e Gestão, 2015)

- Banco Mundial (BM)/Banco Internacional para Reconstruções e Desenvolvimento (BIRD)

- Banco Interamericano de Desenvolvimento (BID)

- Corporação Andina de Fomento (CAF)

- Agência Francesa de Desenvolvimento (AFD)

- Japan Bank for International Cooperation (JBIC) - Banco Japonês

- Kreditanstalt für Wiederaufbau (KFW) - Banco Alemão

- Global Environment Facility (GEF)

- Fundo para o Desenvolvimento da Bacia do Prata (Fonplata)

- Fundo Internacional para Desenvolvimento da Agricultura (FIDA)

4) Pessoas Jurídicas, divididas nos subgrupos:

- Empresas com investimento Social Privado

- Empresas com Recursos Incentivados - Leis de Incentivo e Fundos Sociais

- Empresas com Recursos Incentivados - Entidades Civis Sem Fins Lucrativos 
- Empresas Instituições Financeiras - com Microcrédito

- Empresas Instituições Financeiras - Fundos de Investimento de Impacto

5) Instituições de Finanças Comunitárias, subdivididos em:

- Cooperativa de crédito

- Bancos Comunitários

6) Fundações e Associações

7) Pessoas físicas, subdivididos em:

- Doação

- Recursos incentivados

Para fins desta pesquisa: dado que há inúmeras possibilidades de fontes de captação de recursos disponíveis, iríamos, inicialmente, analisar ao balanço das organizações e verificar se há a divisão de receita por tipos de fontes de captação. Dado que esta informação, dividida por fonte, só foi possível de ser obtida em um dos empreendimentos - o Doutores da Alegriaoptou-se por incluir algumas perguntas no questionário de pesquisa fazendo alusão às fontes e seus percentuais de participação.

Num primeiro questionário, testado em pré-teste, ao perguntar aos entrevistados sobre as várias possibilidades de fontes de recurso, bem como quais delas o empreendimento acionava e fazia uso, não houve resposta clara ou completa o suficiente devido à nomenclatura "fontes de captação", algumas vezes, ter sido confundida com conceitos como projetos da associação, que estavam em processo de captação. Para solucionarmos esta questão, enumeramos as várias fontes de captação, trazidas pelos autores citados acima, afim de colaborar no entendimento das perguntas e geração de respostas consistentes e fiéis à realidade do conceito.

Quanto ao aspecto estratégia de captação, à luz desta pesquisa e visando não limitar as possibilidades de resposta dos entrevistados, elaboramos as perguntas, que compõem o questionário e que se referem à estratégia, com escopo amplo e sem enumerar quais são os possíveis tipos de estratégias que o entrevistado possa fazer uso, afim de não influenciar a amostra, bem como por não termos um modelo referenciado para o ecossistema de empreendimento sociocultural.

Quanto à vertente estrutura de captação de recursos de empreendimentos socioculturais, focaremos no conceito mais amplo de pessoas ou equipes dedicadas a captar recursos, conforme Cruz; Estraviz (2000) enfatiza: a importância de todos na organização social estarem envolvidos na captação, tendo um líder responsável por ela. 
Caso haja uma estrutura interna definida e nomeada pelo empreendimento estudado como uma área dedicada à esta atividade, a presente pesquisa considerará que a estrutura é interna, definida e dedicada à captação.

Caso o empreendimento tenha optado por contratar serviços de terceiros para exercem a atividade de captação de recursos, a presente pesquisa considerará que a estrutura de captação é terceirizada. Neste tópico, procuraremos entender o porquê e como a prestação de serviço é contratada.

Isto posto, o empreendimento poderá ser classificado, quanto a este aspecto em:

- Estrutura interna dedicada à captação (sendo composta por pessoas, que exercem a função ou área definida para tal atividade).

- Terceirização da captação de recursos

- Estrutura mista: composta por estrutura interna + terceirização da captação.

\subsection{Das Leis de Incentivo}

A primeira lei de incentivo, que começou a vigorar no Brasil, e que até hoje existe é a Lei Rouanet ${ }^{20}$. Esta foi uma lei criada com fins de apoiar, propagar, preservar a cultura brasileira, através de um sistema de administração pública "compartilhada", em que o setor privado e o público pudessem juntos, eleger as práticas artísticos culturais brasileiras, sendo que ambos desempenhariam responsabilidades, que se seguem:

- O poder público seria responsável pela seleção, curadoria e triagem de projetos culturais aptos a receber recursos. E o poder público daria como contrapartida a renúncia fiscal do imposto a ser pago pela organização privada à federação;

- E do outro lado, o poder privado - representado pelas empresas que têm regime de tributação baseados no lucro real - como responsáveis pela escolha dos projetos - já aptos à receber recurso - para a destinação da renúncia fiscal de sua companhia.

A legislação de incentivos fiscais passa a vigorar no Brasil, a partir da década de 1990, inicialmente com a Lei Sarney, que durou pouco mais de dois anos, e depois com a Lei Rouanet, atual carro chefe das leis de incentivo no país e principal mecanismo de fomento à Cultura do Brasil (MINC, 2017).

\footnotetext{
${ }^{20}$ Lei criada em 1991, Lei 8.313/91, instituiu o Programa Nacional de Apoio à Cultura (Pronac).
} 
Depois da Lei Rouanet, outras milhares de leis e fundos sociais surgiram com o mesmo mecanismo de incentivo: de um lado, a esfera pública responsável pelas seleções, curadorias e aprovações de projetos aptos a receberem recursos - dando como contrapartida a renúncia fiscal de parte de seus impostos a serem recebidos pelas empresas e de outro, as empresas podendo escolher, dentre os projetos aprovados previamente pela esfera pública, os projetos aos quais gostariam de apoiar via destinação de parte de seus impostos; seguindo sempre as premissas que cada lei ou fundo de incentivo determina como percentual passível de renúncia fiscal governamental.

Um grande equívoco, comumente estabelecido, quando se trata do conceito de leis de incentivo é que o imposto pago pela empresa é abatido do pagamento final deste ao governo, não sendo desembolsado na totalidade. Mas, na realidade o abatimento ocorre, quando a empresa vai pagar seus impostos à esfera governamental, mas desembolso também ocorre no momento de incentivar um projeto. Resumidamente, ao invés de direcionar parte do imposto à esfera pública, a empresa direciona esta parte ao projeto ao qual escolher, dentre os aprovados e aptos a receber recurso via lei.

As leis de incentivo podem ser federais, estaduais e municipais assim como os fundos sociais. Cada legislação tem as suas inúmeras particularidades tanto para o projeto incentivado como para a empresa incentivadora, mas se tivéssemos que eleger o que a torna federal, estadual ou municipal, além da esfera a qual a lei foi aprovada, poderíamos elencar que é o tipo de imposto renunciado pela esfera governamental, a localidade do CNPJ do proponente e do incentivador e o local ao qual o projeto incentivado deve ser executado, como no quadro abaixo:

\begin{tabular}{|r|r|r|r|r|}
\hline $\begin{array}{c}\text { Esfera } \\
\text { Governamental }\end{array}$ & $\begin{array}{c}\text { Impostos } \\
\text { para renúncia }\end{array}$ & $\begin{array}{r}\text { CNPJ do } \\
\text { proponente }\end{array}$ & $\begin{array}{r}\text { CNPJ do } \\
\text { incentivador }\end{array}$ & $\begin{array}{r}\text { Local de } \\
\text { execução do } \\
\text { projeto }\end{array}$ \\
\hline Federal & $\begin{array}{c}\text { Imposto } \\
\text { de Renda (IR) }\end{array}$ & federação & federação & federação \\
\hline Estadual & ICMS & $\begin{array}{c}\text { estado da } \\
\text { lei }\end{array}$ & $\begin{array}{c}\text { estado da } \\
\text { lei }\end{array}$ & $\begin{array}{c}\text { estado da } \\
\text { lei }\end{array}$ \\
\hline Municipal & $\begin{array}{c}\text { IPTU, } \\
\text { ISS }\end{array}$ & $\begin{array}{c}\text { município } \\
\text { da lei }\end{array}$ & $\begin{array}{c}\text { município } \\
\text { da lei }\end{array}$ & $\begin{array}{c}\text { município } \\
\text { da lei }\end{array}$ \\
\hline
\end{tabular}


O quadro acima evidencia a premissa elementar de funcionamento das leis de incentivo: a esfera pública renuncia parte do imposto ao qual legisla, contanto que o projeto seja incentivado e executado no território que esfera pública existe, bem como o produtor responsável pelo projeto (conhecido também como proponente, em termos legislativos) resida na mesma. Isto é feito com o objetivo de disseminar e promover a cultura da localidade, através de impostos locais.

Hoje existem mais de 30 leis de incentivo no Brasil, cada uma delas pertencente a um estado, munícipio ou à própria federação. As diferenças no processo de utilização da lei, por toda a cadeia artístico cultural no Brasil, é vasta, mas pensando no ecossistema estudado nesta pesquisa, as leis de incentivo as quais estas organizações poderiam fazer uso são da federação, do estado de São Paulo e do munícipio de São Paulo. O quadro abaixo mostra as principais leis de incentivo existentes nestas esferas e suas diferenças quanto ao imposto a ser utilizado e o percentual passível de renúncia fiscal:

\begin{tabular}{|r|l|}
\hline \multicolumn{1}{|c|}{ Leis | Fundos } & \multicolumn{1}{c|}{$\begin{array}{c}\% \text { limite } \\
\text { imposto }\end{array}$} \\
\hline Lei Estadual da Cultura (ProAC) & $3 \%$ ICMS \\
\hline Lei Estadual do Esporte (PIE) & $3 \%$ ICMS \\
\hline Lei Federal da Cultura (Rouanet) & $4 \%$ IR \\
\hline Lei do Áudio Visual & $3 \%$ IR \\
\hline Lei Federal do Esporte & $1 \%$ IR \\
\hline Incentivo Fiscal ao Idoso (FDI) & $1 \%$ IR \\
\hline Incentivo Fiscal à Criança (FIA, FUMCAD OU CONDECA) & $1 \%$ IR \\
\hline Incentivo Fiscal à Saúde Oncológica (PRONON) & $1 \%$ IR \\
\hline Incentivo Fiscal à Pessoa com Deficiência (PRONAS) & $1 \%$ IR \\
\hline
\end{tabular}

Quadro 7 - Diferenças entre impostos e limites de renúncia por lei | fundo

(Quadro Elaborado pela Autora)

Das leis e fundos elencados acima, para fins únicos e exclusivos da Cultura aqui nomeada há somente três, a Lei Rouanet, a Lei do Áudio Visual e o ProAC, e falaremos mais adiante sobre cada uma delas.

O mecanismo de lei de incentivo extrapolou o âmbito da cultura, e foi abraçado também para iniciativas esportivas, da saúde e sociais e isto se reflete nas outras seis leis e fundos que compõem o quadro. Importante salientar que estas leis não concorrem entre si pela utilização dos recursos a serem destinados pelas empresas, ou seja, toda organização, que estiverem em conformidade com o que a lei, a qual deseja fazer uso, exige, pode investir em projetos culturais, esportivos, sociais e da saúde. 
Essa realidade, permite à iniciativa privada um potente incentivo para focalizar-se na promoção nacional em seus diversos âmbitos: sociais, educacionais, esportivos e artísticos culturais. Dito isso, apresenta-se agora um breve panorama histórico de cada uma das leis de incentivo à Cultura no Brasil.

\subsubsection{Lei Sarney}

A primeira lei estabelecida de fato com o objetivo de incentivar a cultura por meios de deduções fiscais foi a Lei n.7.505/86, de 1986, mais conhecida como a Lei Sarney (em referência ao sobrenome do político que a criou). Em 1990, com a lei n. 8.034/90, seria suspensa a lei Sarney.

\subsubsection{Lei Rouanet (Federal)}

Um ano depois do fim da Lei Sarney, ou seja, em 1991, viria promulgada a Lei n. 8.313/91, mais conhecida como a Lei Rouanet, que teria como responsabilidade corrigir as distorções da lei precedente, lei Sarney. Segundo o Ministério da Cultura (2017), o nome Rouanet remete a seu criador, o então secretário Nacional de Cultura, o diplomata Sérgio Paulo Rouanet.

A Lei foi concebida originalmente com três mecanismos: o Fundo Nacional da Cultura (FNC), o Incentivo Fiscal e o Fundo de Investimento Cultural e Artístico (Ficart). Este último nunca foi implementado, enquanto o Incentivo Fiscal - também chamado de mecenato prevaleceu e isto ocorreu, pois, em sua formatação e aplicação, ao longo de todos os anos, a Lei Rouanet privilegiou de maneira muito evidente o mecanismo de incentivo, a ponto de ter se tornado sinônimo de incentivo fiscal. O FNC não dispôs de prerrogativas que garantissem sua potência e crescimento equilibrado, nem mesmo sua estabilidade, e ficou diminuído ${ }^{21}$.

De acordo com o Ministério da Cultura (2017), o Fundo Nacional da Cultura (FNC) representa o investimento direto do Estado no fomento à Cultura, já que o apoio a projetos decorre de recursos do orçamento da União dentre outras fontes, como $3 \%$ do valor bruto arrecado pelas loterias federais e doações. O apoio via FNC tem como objetivo, segundo MinC,

21 Disponível em: http://www.cultura.gov.br/noticias-destaques/-/asset_publisher/OiKX3xlR9iTn/content/oincentivo-fiscal-e-a-lei-rouanet/10883. Acesso em: 22 de dezembro de 2017. 
promover a distribuição regional dos recursos de forma equilibrada e é voltado aos projetos com maior dificuldade de captação junto ao mercado. O fomento se dá por meio de editais de seleção.

A Lei Rouanet é utilizada por empresas que tenham regime de tributação no lucro real e por pessoas físicas brasileiras, que pagam impostos federais.

A Lei, como todas as leis de incentivo, é uma política pública que visa acesso e democratização da cultura a todo e qualquer cidadão brasileiro. Ela foi concebida para permitir a atuação conjunta do público e privado, na construção e manutenção da cultura brasileira à todo cidadão.

Por ser a lei de incentivo mais antiga vigente até os dias de hoje, ela ajudou a moldar e ditar diretrizes nos demais âmbitos da Cultura: as demais leis que vieram, após a lei Rouanet, levam os mesmos princípios e missões dos investimentos aos pertencentes ao ecossistema cultural ao qual elas pertencem e impactam, sofrendo adaptações de acordo com a esfera governamental a qual a lei pertence. São o caso das leis estaduais, que também permitem às empresas privadas deduzirem parte de seus impostos estaduais devidos.

A Lei Rouanet iniciou com 19 projetos apresentados, 10 projetos aprovados e 2 projetos que efetivamente receberam recursos; no ano de 2017, foram 4.976 projetos apresentados, 5.445 projetos aprovados, aqui o número é maior, pois geralmente se aprovam projetos apresentados também em finais de exercício de 2016 e 2.804 projetos que receberam recursos.

A grande maioria dos recursos recebidos, bem como projetos aprovados e apresentados estão na região Sudeste, mais especificamente em São Paulo, conforme quadros abaixo: 


\begin{tabular}{|c|c|c|}
\hline \multirow{5}{*}{ Centro Oeste } & DF & 89,00 \\
\hline & GO & 64,00 \\
\hline & MS & 13,00 \\
\hline & MT & 23,00 \\
\hline & Total & 189,00 \\
\hline \multirow{10}{*}{ Nordeste } & $\mathrm{AL}$ & 7,00 \\
\hline & BA & 107,00 \\
\hline & $\mathrm{CE}$ & 98,00 \\
\hline & MA & 19,00 \\
\hline & PB & 19,00 \\
\hline & PE & 127,00 \\
\hline & PI & 7,00 \\
\hline & $\mathrm{RN}$ & 21,00 \\
\hline & SE & 11,00 \\
\hline & Total & 416,00 \\
\hline \multirow{8}{*}{ Norte } & $\mathrm{AC}$ & 1,00 \\
\hline & AM & 22,00 \\
\hline & $\mathrm{AP}$ & 2,00 \\
\hline & $\mathrm{PA}$ & 35,00 \\
\hline & $\mathrm{RO}$ & 5,00 \\
\hline & $\mathrm{RR}$ & 3,00 \\
\hline & $\mathrm{TO}$ & 10,00 \\
\hline & Total & 78,00 \\
\hline \multirow{5}{*}{ Sudeste } & ES & 52,00 \\
\hline & $\mathrm{MG}$ & 672,00 \\
\hline & RJ & $1.075,00$ \\
\hline & SP & $1.684,00$ \\
\hline & Total & $3.483,00$ \\
\hline \multirow{4}{*}{ Sul } & PR & 384,00 \\
\hline & $\mathrm{RS}$ & 590,00 \\
\hline & $\mathrm{SC}$ & 305,00 \\
\hline & Total & $1.279,00$ \\
\hline \multicolumn{2}{|c|}{ Total } & $5.445,00$ \\
\hline
\end{tabular}

Quadro 8 - Número de projetos aprovados por estado | Lei Rouanet 2017 (dados MinC 2017)

(Quadro Elaborado pela Autora) 


\begin{tabular}{|l|r|}
\hline \multicolumn{2}{|c|}{$\mathbf{2 0 1 7}$} \\
\hline $\begin{array}{c}\text { Proje to por região } \\
\text { es tado }\end{array}$ & Quantidade \\
\hline Centro Oeste & 63,00 \\
\hline Distrito Federal & 32,00 \\
\hline Goiás & 14,00 \\
\hline Mato Grosso & 10,00 \\
\hline Mato Grosso do Sul & 7,00 \\
\hline Nordeste & 206,00 \\
\hline Alagoas & 1,00 \\
\hline Bahia & 33,00 \\
\hline Ceará & 85,00 \\
\hline Maranhão & 7,00 \\
\hline Paraíba & 11,00 \\
\hline Pernambuco & 48,00 \\
\hline Piaú & 7,00 \\
\hline Rio Grande do Norte & 9,00 \\
\hline Sergipe & 5,00 \\
\hline Norte & 32,00 \\
\hline Amazonas & 4,00 \\
\hline Pará & 19,00 \\
\hline Rondônia & 3,00 \\
\hline Tocantins & 6,00 \\
\hline Sudeste & $1.600,00$ \\
\hline Espírito Santo & 22,00 \\
\hline Minas Gerais & 349,00 \\
\hline Rio de Janeiro & 363,00 \\
\hline São Paulo & 866,00 \\
\hline Sul & 903,00 \\
\hline Paraná & 259,00 \\
\hline Rio Grande do Sul & 430,00 \\
\hline Santa Catarina & 214,00 \\
\hline Total & $2.804,00$ \\
\hline & \\
\hline
\end{tabular}

Quadro 9 - Número de projetos com recursos recebidos por estado | Lei Rouanet 2017 (dados MinC 2017)

(Quadro Elaborado pela Autora) 


\begin{tabular}{|c|c|c|}
\hline \multirow{5}{*}{ Centro Oeste } & Distrito Federal & 86 \\
\hline & Goiás & 61 \\
\hline & Mato Grosso & 24 \\
\hline & Mato Grosso do Sul & 10 \\
\hline & Total & 181 \\
\hline \multirow{10}{*}{ Nordeste } & Alagoas & 7 \\
\hline & Bahia & 99 \\
\hline & Ceará & 95 \\
\hline & Maranhão & 15 \\
\hline & Paraíba & 20 \\
\hline & Pernambuco & 105 \\
\hline & Piauí & 6 \\
\hline & Rio Grande do Norte & 18 \\
\hline & Sergipe & 8 \\
\hline & Total & 373 \\
\hline \multirow{8}{*}{ Norte } & Acre & 1 \\
\hline & Amapá & 2 \\
\hline & Amazonas & 23 \\
\hline & Pará & 35 \\
\hline & Rondônia & 4 \\
\hline & Roraima & 3 \\
\hline & Tocantins & 10 \\
\hline & Total & 78 \\
\hline \multirow{5}{*}{ Sudeste } & Espírito Santo & 52 \\
\hline & Minas Gerais & 626 \\
\hline & Rio de Janeiro & 955 \\
\hline & São Paulo & 1.519 \\
\hline & Total & 3.152 \\
\hline \multirow{4}{*}{ Sul } & Paraná & 351 \\
\hline & Rio Grande do Sul & 561 \\
\hline & Santa Catarina & 280 \\
\hline & Total & 1.192 \\
\hline & Total & 4.976 \\
\hline
\end{tabular}

Quadro 10 - Número de projetos apresentados por estado | Lei Rouanet 2017 (dados MinC 2017)

(Quadro Elaborado pela Autora)

Vale apontar que a amostra estudada nesta pesquisa reside em São Paulo, e todas fazem uso dos recursos da Lei Rouanet. 


\subsubsection{Lei Estadual da Cultura (ProAC | ICMS do estado de São Paulo)}

Em 2006, o Programa de Ação Cultural coordenado pela Secretaria do Estado da Cultura de São Paulo, criaria a Lei Estadual da Cultura concedendo a pessoas jurídicas, a possibilidade de deduções fiscais, quando realizarem investimentos em projetos culturais, previamente aprovados pela Secretaria da Cultura, em moldes similares à lei federal da Cultura juntamente com os Editais da Cultura (Edital ICMS0).

A Lei Estadual da Cultura é mais comumente conhecida pela sigla ProAC | ICMS, pois permite a dedução fiscal de ICMS - que é o Imposto sobre operações relativas à Circulação de Mercadorias e sobre Prestações de Serviços de Transporte Interestadual e Intermunicipal e de Comunicação.

Esta lei tem como condição que as empresas, as quais farão uso da lei, sejam contribuintes de ICMS dentro do estado de São Paulo. O ProAC | ICMS é realizado com recursos de renúncia fiscal do Estado de São Paulo: o Governo autoriza que empresas, credoras de ICMS e previamente habilitadas, deixem de recolher parte do imposto devido, destinando os valores diretamente a projetos culturais aprovados pela Secretaria da Cultura.

O Programa de Ação Cultural, ao qual o ProAC| ICMS, lei nº 12.268 , faz parte tem como diretrizes:

I - Apoiar e patrocinar a renovação, o intercâmbio, a divulgação e a produção artística e cultural no Estado;

II - Preservar e difundir o patrimônio cultural material e imaterial do

Estado;

III - Apoiar pesquisas e projetos de formação cultural, bem como a diversidade cultural;

IV - Apoiar e patrocinar a preservação e a expansão dos espaços de circulação da produção cultural. (Lei $\mathbf{n}^{\mathbf{0}} \mathbf{1 2 . 2 6 8}$, de 20 de fevereiro de 2006).

O Programa de Ação Cultural não libera dados de fácil manipulação com o número de projetos apresentados, aprovados e captados por ano, por isso não conseguimos exemplificar e quantificar o tamanho da lei para promoção, apoio e preservação da cultura no estado de São Paulo, apesar de sabermos por experiência empírica que esta lei é amplamente utilizada como fonte de recurso de captação por empreendimentos socioculturais sediados no estado de São Paulo, foco primordial desta dissertação. 


\section{METODOLOGIA}

O ponto de partida da pesquisa, o qual gerou a questão supracitada "Como é a captação de recursos dos empreendimentos socioculturais, sob a ótica da estrutura, estratégias e fontes de captação?", tem suas raízes na experiência prática da autora deste trabalho em empreender na área sociocultural, bem como vivenciar planejamentos de captação de recursos neste e para este ecossistema. Tal fato, enquadra a dissertação como pertinente a um programa de mestrado profissional em administração, uma vez que o problema de pesquisa, para programas dessa natureza, nasce à luz da experiência prática do autor do trabalho (KRAKAUER, P, et.al.,2015). Os métodos escolhidos tiveram como determinante, portanto, serem a escolha que auxilia na construção da resposta à pergunta acima, não deixando de cumprir seu papel de relevância, confiabilidade e robustez acadêmico-científico aliados ao que a realidade prática exige.

\subsection{Caracterização da Pesquisa}

Como, já vimos acima, o ponto de partida da pesquisa será a experiência da própria autora, deste trabalho, em empreender e captar recursos na área sociocultural- portanto, podese considerar que o presente trabalho está alinhado à diretriz de pesquisa proposta por KRAKAUER, P (2015), para mestrados profissionais em administração.

Uma vez a pesquisa estando em conformidade com o que é esperado de um trabalho produzido num mestrado profissional, classificaremos a pesquisa conforme os quatro eixos abaixo:

\subsubsection{Perspectiva dos Objetivos de Pesquisa}

Do ponto de vista de seu objetivo, que é analisar como os empreendimentos socioculturais captam recursos, a pesquisa pode ser considerada exploratória. A pesquisa é considerada exploratória, quando ainda há pouco conhecimento sobre o tema. Segundo GIL (2002), a pesquisa exploratória visa proporcionar maior familiaridade com o problema com vistas a torná-lo explícito ou a construir hipóteses, envolvendo levantamento bibliográfico; entrevistas com pessoas que tiveram experiências práticas com o problema pesquisado e análise de exemplos que estimulem a compreensão, exatamente como foi feito nesta pesquisa. 


\subsubsection{Perspectiva do "meio" para se alcançar os resultados / Estratégias de Pesquisa}

Para chegarmos a melhor estratégia de pesquisa, utilizamos como base o trabalho feito por YIN (2003, p. 24), em que ele destaca que a primeira e mais importante condição para se diferenciar as várias estratégias de pesquisa é identificar nela o tipo de questão que está sendo apresentada. É provável que questões "como" e "por que" estimulassem o uso de estudos de caso, experimentos ou pesquisas históricas. Dado que a questão de pesquisa deste trabalho é da categoria "como", cabe analisar às três estratégias indicadas acima pelo autor.

Assumindo-se que questões do tipo "como" e "por que" devam ser o foco do estudo, uma distinção adicional entre pesquisa histórica, estudo de caso e experimento, segundo YIN (2003, p. 25), é a abrangência do controle que o pesquisador tem sobre eventos comportamentais efetivos e o acesso a eles. As pesquisas históricas representam a estratégia escolhida quando realmente não existe controle ou acesso. Assim, a contribuição distintiva do método histórico está em lidar com o passado "morto" - isto é, quando nenhuma pessoa relevante ainda está viva para expor, o que aconteceu, e quando o pesquisador deve confiar, como fonte principal de evidências, em documentos primários, secundários e artefatos físicos e culturais, o que não é o caso da presente pesquisa, dado que todos os empreendimentos tem seus respondentes vivos e vivenciando aos fatos reais. O estudo de caso é a estratégia escolhida ao se examinarem acontecimentos contemporâneos, mas quando não se podem manipular comportamentos relevantes. $\mathrm{O}$ estudo de caso conta com muitas das técnicas utilizadas pelas pesquisas históricas, mas acrescenta duas fontes de evidências que usualmente não são incluídas no repertório de um historiador: observação direta e entrevistas. Já o experimento permite ao pesquisador controlar os eventos pesquisados, como num laboratório, por exemplo.

Considerando a natureza da questão de pesquisa e que os eventos e comportamentos relevantes ao tema captação de recursos não podem ser controlados pelo autor do trabalho, em cada empreendimento estudado, consideraremos a estratégia de estudos de caso, mais especificamente estudo de casos múltiplos holísticos, conforme definição abaixo, como a principal estratégia que norteará a presente pesquisa.

Yin (2003, p.61) apresenta quatro tipos básicos de estudo de caso:

1. Projetos de caso único holístico - unidade única de análise e único caso;

2. Projetos de caso único incorporado - unidades múltiplas de análise e único caso;

3. Projetos de casos múltiplos holísticos - unidade única de análise e múltiplos casos; 
4. Projetos de casos múltiplos incorporados - unidades múltiplas de análise e múltiplos casos.

Adotaremos a terceira, por ser a que melhor representa nossa pesquisa: temos seis empreendimentos como exemplos de casos a serem analisados sob a perspectiva da captação de recursos.

YIN (2003, p. 51) destaca a importância da utilização da teoria, ao realizar-se estudos de caso, pois essa, não apenas representa uma ajuda imensa na definição do projeto de pesquisa e na coleta de dados adequados, como também se torna o veículo principal para uma possível padronização e, consequente, comparação dos resultados do estudo de caso. Veremos, mais adiante, que o questionário de pesquisa, bem como as análises de dados foram divididas por categorias, baseadas em teoria, afim de que a comparação de resultados fosse possível.

\subsubsection{Abordagem estratégica do problema}

A pesquisa é classificada como qualitativa, segundo abordagem do problema, pois proporciona uma melhor visão e compreensão do problema, além de auxiliar no desenvolvimento da abordagem, adequada ao pesquisador que se depara com uma situação de incerteza (MALHOTRA, 2011). A presente pesquisa pode ser considerada qualitativa, pois, além de se ter pouco conhecimento produzido sobre o problema de pesquisa, esta considera que há uma relação dinâmica entre o mundo real e o sujeito, isto é, um vínculo indissociável entre o mundo objetivo e a subjetividade do sujeito que não pode ser traduzido em números.

O quadro abaixo, baseado em Bauer, Gaskell (2002) ilustra as diferenças entre pesquisa qualitativa e quantitativa:

\begin{tabular}{|c|c|c|}
\hline Estratégia & Qualitativa & Quantitativa \\
\hline Dados & Números & Textos \\
\hline Análise & Estatistica & Interpretação \\
\hline Protótipo & $\begin{array}{c}\text { Pesquisas de } \\
\text { Opinião }\end{array}$ & $\begin{array}{c}\text { Entrevistas em } \\
\text { Profundidade }\end{array}$ \\
\hline
\end{tabular}

Quadro 11 - Diferenças entre pesquisa qualitativa e quantitativa 
O quadro acima reforça ainda mais a definição da pesquisa como qualitativa, dado que a presente pesquisa é exploratória e se utiliza principalmente do estudo de caso múltiplo para compreensão do problema, através de análises interpretativas das respostas obtidas nas entrevistas em profundidade. Falaremos mais adiante, ainda neste capítulo, sobre a escolha das entrevistas como instrumento de coleta de dados.

\subsubsection{Perspectiva da Utilização dos Resultados Obtidos}

De acordo com Barros e Lehfeld (2000), a pesquisa aplicada tem como motivação a necessidade de produzir conhecimento para aplicação de seus resultados, com o objetivo de contribuir para fins práticos, visando a solução do problema encontrado na realidade. É importante salientar, que, por outro lado, a forma alternativa de utilização e contribuição do resultado da pesquisa é a produção e disseminação do conhecimento obtido, pesquisa conhecida como pura. Tanto a pesquisa aplicada como a pura não são excludentes. Considerando que este trabalho objetiva produzir conhecimento, através da análise de como os empreendimentos socioculturais captam recursos sob três aspectos: estratégia, estrutura e fontes de captação, bem como tem a motivação em contribuir para soluções práticas no processo de captação de recursos, através dos resultados de pesquisa obtidos, podemos classificar a pesquisa, sob esta ótica, como aplicada e pura.

\subsection{Público Pesquisado}

A amostra escolhida para representar o universo pesquisado foi não probabilística e intencional. Por ser um estudo de caso múltiplo, o número de respondentes da amostra não faz diferença, segundo Yin (2003, p. 72), mas sim as características similares dos respondentes, representando o universo ao qual a pesquisa fará referência. O número de respondentes não importa, pois não deve ser utilizada uma lógica de amostragem, os critérios típicos adotados em relação ao tamanho da amostragem se tornam irrelevantes. De preferência, é importante o pesquisador pensar na decisão do número de respondentes como um reflexo do número de replicações de caso que gostaria de ter em seu estudo. Somente, recapitulando que no processo de escolha da amostra, era importante, então, considerar que estes empreendimentos deveriam representar o universo de pesquisa e que seriam comparados, devendo para tanto, possuírem algumas características similares. As características escolhidas foram: 
- Seus projetos serem manifestações artísticas que gerem benefício social

- Benefício social ser o acesso bem como a formação artística a quem não pode usufruíla, seja por questões socioeconômicas, sócio - demográficas ou físico-intelectuais.

- Residirem no Estado de São Paulo - por ser o estado que mais produz projetos culturais, conforme visto no referencial teórico.

- Tem no mínimo 5 anos de atuação - afim de demostrarem mínima consolidação de sua atuação sociocultural e respectiva manutenção das atividades ininterruptamente.

Os quadros abaixo ilustram como estas características aparecem em cada empreendimento:

\begin{tabular}{|c|c|c|c|c|c|}
\hline Empreendimentos SocioCulturais & $\begin{array}{c}\text { Tempo de } \\
\text { Existência } \\
\text { Formal (anos) }\end{array}$ & $\begin{array}{c}\text { Endereço } \\
\text { Social SP }\end{array}$ & $\begin{array}{c}\text { Endereço } \\
\text { Atuação }\end{array}$ & $\begin{array}{c}\text { Manifestação } \\
\text { Artistica }\end{array}$ & Beneficio Social \\
\hline 1) Produtora Cultural BuZum & 8 & capital & Brasil & Teatro de Marionetes & acesso e formação para crianças \\
\hline 2) ImageMagica OSC & 19 & capital & Brasil & Fotografia & Teatro de Palhaço \\
\hline 3) Doutores da Alegria OSC & 26 & capital & Brasil & Cinesso e formação para crianças, adolescentes e adultos \\
\hline 4) Ibirajá Produções & 5 & capital & Brasil & ação para crianças, adolescentes e adultos \\
\hline 5) Pia Fraus Produtora Teatral & 34 & capital & Brasil & Teatro de Bonecos & acesso e formação para crianças, adolescentes e adultos \\
\hline 6) Cia Vagahum crianças, adolescentes e adultos
\end{tabular}

Quadro 12 - Empreendimentos Socioculturais (Fonte: Quadro Elaborado pela Autora)

\begin{tabular}{|c|c|c|}
\hline Empreendimentos SocioCulturais & Função do Entrevistado & Natureza Juridica \\
\hline 1) Produtora Cultural BuZum & Sócia & Empresa \\
\hline 2) ImageMagica OSC & Fundadora & Organização da Social Civil \\
\hline 3) Doutores da Alegria OSC & $\begin{array}{c}\text { Responsável pela Captação } \\
\text { de Pessoa Juridica }\end{array}$ & Organização da Social Civil \\
\hline 4) Ibirajá Produções & Sócio e Produtor & Empresa \\
\hline 5) Pia Fraus Produtora Teatral & Sócio & Empresa \\
\hline 6) Cia Vagalum Tum Tum de Teatro Infantil & Sócia & Empresa \\
\hline
\end{tabular}

Quadro 13 - Função do Entrevistado e Natureza Jurídica.

(Fonte: Quadro Elaborado pela Autora) 


\subsection{Coleta de Dados}

As fontes de evidências, conforme Yin (2003, p. 107) nomeia como o auxílio mais eficaz na estratégia de estudo de caso, são a documentação, os registros em arquivos, as entrevistas, a observação direta, a observação participante e os artefatos físicos.

A coleta dos dados primários foi realizada por meio da fonte de evidências entrevista, através do Skype, ou presencial ou por telefone, o quadro abaixo elucida qual o meio utilizado para cada entrevistado acompanhado da duração da entrevista estritamente, sem considerar os diálogos prévios e posteriores sobre o tema.

\begin{tabular}{|r|c|c|}
\hline \multicolumn{1}{|c|}{ Empreendimentos SocioCulturais } & Meio & Duração \\
\hline 1) Produtora Cultural BuZum & Skype & 33 minutos \\
\hline 2) ImageMagica OSC & Skype & 27 minutos \\
\hline 3) Doutores da Alegria OSC & Presencial & 21 minutos \\
\hline 4) Ibirajá Produções & Skype & 34 minutos \\
\hline 6) Pia Fraus Produtora Teatral & Skype & 89 minutos \\
\hline 8) Cia Vagalum Tum Tum de Teatro Infantil & Presencial & 37 minutos \\
\hline
\end{tabular}

Quadro 14 - Quadro Meio e Duração das Entrevistas (Quadro Elaborado pela Autora)

O instrumento de pesquisa utilizado, para este estudo, foi questionário com perguntas abertas para ser aplicado por meio de entrevista. O questionário da pesquisa utilizado no préteste é apresentado no Apêndice 2 e a versão final, com ajustes capturados, durante e após a finalização do pré-teste, é apresentada no Apêndice 3. Antes das perguntas serem feitas, a cada entrevistado, apresentou-se uma breve apresentação dos objetivos da entrevista e previsão de sua duração, além da informação a respeito do registro da entrevista por meio de gravação eletrônica para garantir maior confiabilidade no momento de reprodução e análise das respostas (GIL, 2002). Após o consentimento, dava-se início à entrevista.

As entrevistas foram autorizadas, formalmente por escrito por cada entrevistado, para serem transcritas e constam, cada uma delas, nos apêndices 4 a 11 deste trabalho.

Por outro lado, para a coleta de dados secundários foram utilizadas as fontes de evidência nomeadas como documentação e registros em arquivos, através de consultas aos sites 
institucionais de cada empreendimento, materiais institucionais como apresentação de projetos, relatórios de desempenho da instituição, prestação de contas de projetos socioculturais, fotos de projetos, além de observação direta por meio de visitas ao empreendimento e seus projetos afim de avaliar se o projeto emprega a manifestação artística como benefício social classificando o empreendimento como sociocultural.

\subsection{Análises de dados}

A utilização da técnica de análise de conteúdo, proposta pela professora e psicóloga Laurence Bardin, da Universidade de Paris, é utilizada em pesquisas qualitativas no campo das ciências sociais, psicologia, ciências sociais aplicadas CAMARA (2013). E ela foi o método escolhido para análise de dados da presente pesquisa, cumprindo as três etapas necessárias a ela, conforme descrito por BARDIN (2011):

Pré-análise, onde se tem a organização de todos dados a serem analisados. No caso de dados primários coletados por entrevistas, é o momento da transcrição e reunião. No caso de dados secundários é o momento de reunião das documentações e arquivos aos quais o pesquisador fez uso. Para uma boa pré-análise, que garanta confiabilidade dos dados analisados, são necessárias seis características, que se cumpriu à risca:

a) Exaustividade (deve-se esgotar a totalidade da comunicação na entrevista, não omitir nada): a presente pesquisa o fez através da transcrição ipsis literis das entrevistas concedidas;

b) Representatividade (a amostra deve representar o universo): conforme falado no subcapítulo público pesquisado a amostra representa o universo pesquisado;

c) Homogeneidade (os dados devem referir-se ao mesmo tema, serem obtidos por técnicas iguais e colhidos por indivíduos semelhantes);

d) Pertinência (os documentos precisam adaptar-se ao conteúdo e objetivo da pesquisa): todos os documentos e dados colhidos adaptam-se ao objetivo de pesquisa.

e) Exclusividade (um elemento colhido não pode ser classificado em mais que uma categoria): na categorização abaixo e na 2 de amarração isto ficará claro. 
Exploração do material com codificação, classificação e categorização dos dados a serem analisados, afim de que possa se reunir informações à custa de uma esquematização e correlacionar achados de pesquisa. A categorização auxiliou não só a análise de dados, como também permeou a formulação das entrevistas (mesma entrevista para todos), o protocolo do estudo de caso e, ao fim, a análise propriamente dita. Para respondermos à questão central, como é a captação de recursos dos empreendimentos socioculturais, sob a ótica da estrutura, estratégias e fontes de captação; foram criadas 5 categorias de análises, compostas por dados secundários e primários, conforme abaixo:

a) Características do empreendimento: quem são, histórico, tipo de natureza jurídica, faturamento, tempo de existência.

b) Projetos socioculturais: suas manifestações artísticas, número e o perfil das pessoas, prioritariamente atendidas, pelos projetos.

c) Estratégias de Captação: devido à literatura e ao já exposto no referencial teórico optou-se por não haver subdivisões de estratégias de captação, afim de deixar cada empreendimento estudado livre para expor o que faz sem influência do entrevistador ou do questionário de pesquisa.

d) Estrutura de Captação: também como exposto no referencial teórico, esta categoria de análise será vinculada à estrutura ser terceirizada, interna ou mista.

e) Fontes de Captação de Recursos: a presente pesquisa pode identificar as fontes de recurso, que cada empreendimento faz uso, através das respostas dadas ao questionário de pesquisa. Somente o Doutores da Alegria tinha também um gráfico ilustrativo destas participações em seu material institucional.

Tratamento dos resultados - a inferência e interpretação, aqui, após a categorização dos resultados, entra uma atenção aos detalhes dos mesmos somados às observações do pesquisador para a inferência e consequente interpretação dos resultados a ser composta. 


\subsection{Matriz de Amarração de Pesquisa}

\begin{tabular}{|c|c|c|c|c|c|c|c|}
\hline \multicolumn{2}{|c|}{ Objetivos da Pesquisa } & \multirow{2}{*}{$\begin{array}{c}\text { Pontos de investigaçāo } \\
\text { (Questōes Abertas de Pesquisa) }\end{array}$} & \multirow{2}{*}{$\begin{array}{c}\text { Fundamentaçāo } \\
\text { Teórica }\end{array}$} & \multirow{2}{*}{$\begin{array}{c}\text { Técnicas de } \\
\text { coleta de } \\
\text { dados } \\
\text { secundários }\end{array}$} & \multirow{2}{*}{$\begin{array}{c}\text { Técnica de } \\
\text { coleta dos } \\
\text { dados } \\
\text { primários }\end{array}$} & \multirow{2}{*}{\begin{tabular}{|c|} 
Técnica \\
de \\
análise \\
dos \\
dados
\end{tabular}} & \multirow{2}{*}{$\begin{array}{l}\text { Resultados } \\
\text { Esperados }\end{array}$} \\
\hline Geral & Especificos & & & & & & \\
\hline \multirow{4}{*}{\begin{tabular}{|} 
Analisar como os \\
empreendimentos \\
sœioculturais \\
captam recursos \\
sob três \\
aspectos: \\
estratégia, \\
estrutura e fontes \\
de captação.
\end{tabular}} & $\begin{array}{l}\text { Investigar se as } \\
\text { iniciativas } \\
\text { culturais dos } \\
\text { respectivos } \\
\text { empreendimentos } \\
\text { são } \\
\text { sociœculturais. }\end{array}$ & $\begin{array}{l}\text { 1) Qual o nome da sua instituição e qual a sua } \\
\text { atividade nela? } \\
\text { 2) Há quanto tempo ela existe? E você a considera } \\
\text { uma instituição sociocultural } \\
\text { 3) Quantos projetos socioculturais estāo ligados à } \\
\text { esta instituição? Há quanto tempo eles existem? } \\
\text { 4) Qual a missão da instituição? } \\
\text { 5) Os projetos refletem a causa da instituição? } \\
\text { 24) Vocês têm quantos projetos por ano? }\end{array}$ & \multirow{4}{*}{\begin{tabular}{|c|} 
\\
\\
\\
Empreendedorismo \\
Cultural, \\
Empreendedorismo \\
Social, Captaçāo \\
de Recursos, Leis \\
de Incentivo.
\end{tabular}} & \multirow{4}{*}{$\begin{array}{c}\text { documentação } \\
\text { registros em } \\
\text { arquivos }\end{array}$} & \multirow{4}{*}{$\begin{array}{l}\text { entrevista } \\
\text { estrutura } \\
\text { com } \\
\text { questionário } \\
\text { com } \\
\text { perguntas } \\
\text { abertas }\end{array}$} & \multirow{4}{*}{$\begin{array}{c}\text { análise } \\
\text { de } \\
\text { conteúdo }\end{array}$} & \multirow[t]{4}{*}{$\begin{array}{l}\text { 1. Identificar o } \\
\text { processo de } \\
\text { captação de } \\
\text { cada } \\
\text { empreendimento } \\
\text { sociocultural, no } \\
\text { que tange: } \\
\text { estratégia, } \\
\text { estrutura e } \\
\text { fontes de } \\
\text { captação. }\end{array}$} \\
\hline & $\begin{array}{l}\text { Identificar quais } \\
\text { são as estratégias } \\
\text { de captação de } \\
\text { recursos dos } \\
\text { empreendimentos. }\end{array}$ & 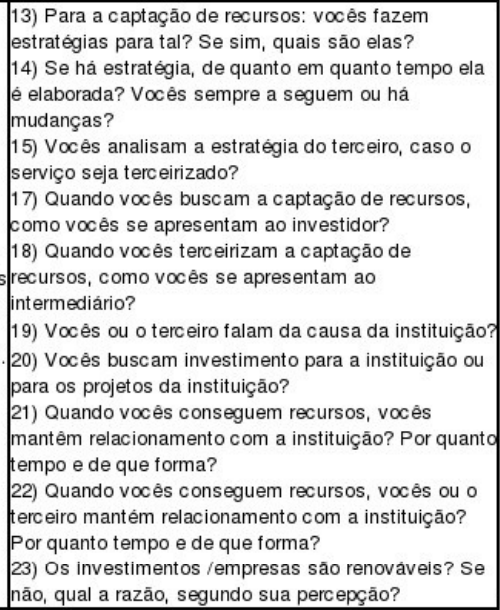 & & & & & \\
\hline & $\begin{array}{l}\text { Identificar quais } \\
\text { são as fontes de } \\
\text { captação de } \\
\text { recursos dos } \\
\text { empreendimentos. }\end{array}$ & $\begin{array}{l}\text { 16) Vocês identificam quais são as potenciais fontes } \\
\text { de recursos? Se sim, como o fazem? E como as } \\
\text { aciona? } \\
\text { 25) Todos estes projetos existem independente das } \\
\text { leis de incentivo ou somente via leis de incentivo? } \\
\text { 26) Se são via leis de incentivo somente, são quais } \\
\text { as leis? } \\
\text { 27) Quais são as fontes de captação destes projetos? } \\
\text { Pessoas fisicas, jurídicas, editais públicos } \\
\text { (estaduais, municipais ou federais), leis de incentivo } \\
\text { (estaduais, municipais ou federais), parcerias de outra } \\
\text { natureza, eventos, prestaçōes de serviço ou o quê? } \\
\text { 28) Você poderia me dizer em percentual de } \\
\text { participação de cada fonte? } \\
\text { 29) Sempre foi assim ou se modificou ao longo dos } \\
\text { anos da instituição? Se se modificou, qual a razão } \\
\text { segundo sua percepção? } \\
\text { 30) Você acredita que você sobreviveria sem leis de } \\
\text { incentivo? } \\
\text { 31) Há uma concorrência alta para o uso destes } \\
\text { recursos, na sua percepção? Se sim, com quem } \\
\text { voês concorrem? }\end{array}$ & & & & & \\
\hline & \begin{tabular}{|} 
Identificar se a \\
estrutura de \\
captação dos \\
empreendimentos \\
é interna, \\
terceirizada ou \\
mista.
\end{tabular} & $\begin{array}{l}\text { 6) Qual a estrutura atual para dedicação à captação } \\
\text { de recursos - nomear o que é - pela sua instituição } \\
\text { ou vocês terceirizam? } \\
\text { 7) Esta estrutura sempre foi a mesma, ao longo dos } \\
\text { anos? Caso não: como era? } \\
\text { 8) Caso não haja estrutura, quem faz a captação de } \\
\text { recursos para a instituição? Há algum responsável ou } \\
\text { a captação é terceirizada? } \\
\text { 9) Caso seja terceirizada, como vocês escolhem a } \\
\text { empresa terceirizada? } \\
\text { 10) Caso haja mais de uma empresa, como voês } \\
\text { controlam a captação? } \\
\text { 11) São quantos? } \\
\text { 12) Porque vocês escolheram terc eirizar? }\end{array}$ & & & & & \\
\hline
\end{tabular}

Quadro 15 - Matriz de amarração de pesquisa.

(Fonte: Quadro Elaborado pela autora inspirado na matriz de amarração de Mazzon) 


\section{ANÁLISES E RESULTADOS}

\subsection{Considerações Gerais}

Neste capítulo, as análises e os resultados serão apresentados pautados nos dados primários - obtidos em entrevistas; e secundários - obtidos em análise documental e de arquivos, conforme elucidado no capítulo METODOLOGIA acima.

As análises serão, primeiramente, divididas por estudo de caso, baseado nas categorias abaixo:

- Características do empreendimento: quem são, histórico, tipo de natureza jurídica, faturamento, tempo de existência.

- Projetos socioculturais: suas manifestações artísticas, número e o perfil das pessoas, prioritariamente atendidas, pelos projetos

- Estratégias de Captação: devido à literatura e ao já exposto no referencial teórico optou-se por não haver subdivisões de estratégias de captação, afim de deixar cada empreendimento estudado livre para expor o que faz sem influência do entrevistador ou do questionário de pesquisa.

- Estrutura de Captação: também como exposto no referencial teórico, esta categoria de análise será vinculada à estrutura ser terceirizada, interna ou mista.

- Fontes de Captação de Recursos: a presente pesquisa pode identificar as fontes de recurso, que cada empreendimento faz uso, através das respostas dadas ao questionário de pesquisa. Somente o Doutores da Alegria tinha também um gráfico ilustrativo destas participações em seu material institucional.

A ordem de apresentação das análises de cada empreendimento não tem relação alguma com a ordem em que o empreendimento foi visitado ou entrevistado.

Em seguida, serão analisados os seis empreendimentos de forma comparativa, também baseado nas categorias acima.

Para a apresentação de resultados serão consideradas, adicionalmente às categorias, a observação direta realizada pela autora deste trabalho. Os resultados serão apresentados também de forma individual e comparativa. 


\subsection{BuZum}

"Teatro e educação são o combustivel que movem o Buzum! Brasil afora."

(Frase retirada do site do empreendimento.)

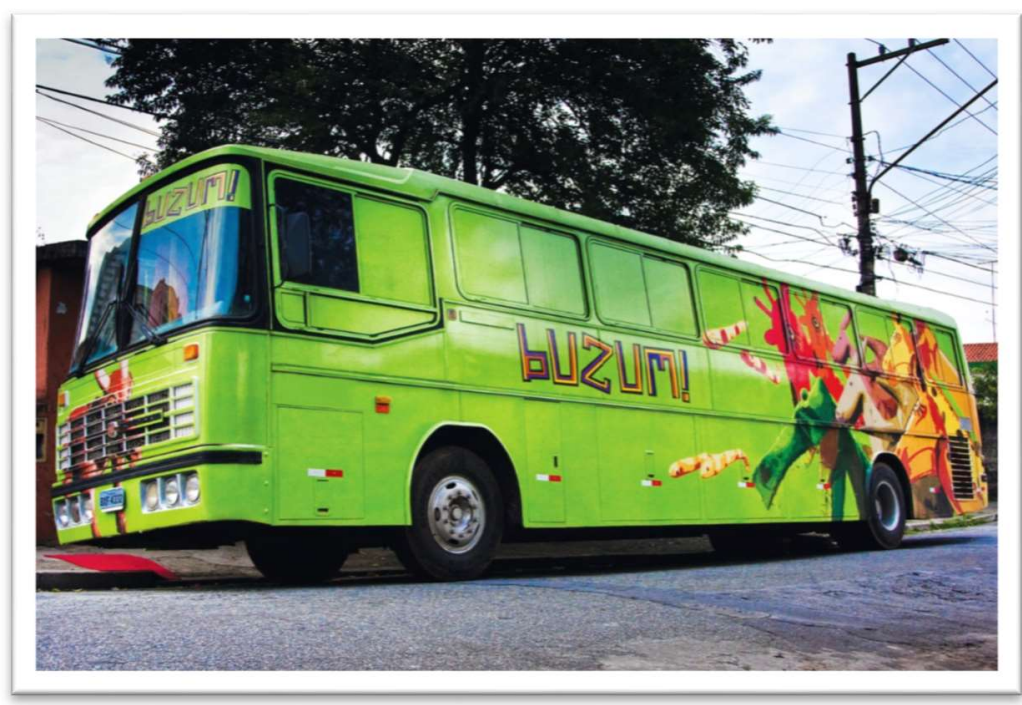

Figura 3 - Ônibus BuZum

(fonte: http://centroculturalpompeia.blogspot.it/2014/11/buzum-na-6-feira-de-artes-e-cultura-da.html)

\subsubsection{Características do empreendimento}

Quem são, histórico, tipo de natureza jurídica, faturamento, tempo de existência

Este empreendimento é uma empresa, com oito anos de história. Nascido em setembro de 2010, da vontade conjunta de Beto Andretta, Jackson Íris e Mari Gutierrez, esta última a produtora executiva do projeto. Eles uniram paixão e experiência para levar teatro de bonecos para escolas, prioritariamente, onde crianças e adolescentes que ainda não conhecessem ou tivessem dificuldade de acesso a esse mundo lúdico pudessem vivenciá-lo.

Atualmente, a organização tem uma receita média de R\$ 1,5 milhões, que segundo o entrevistador, sustenta a organização financeiramente. 


\subsubsection{Projetos socioculturais}

Suas manifestações artísticas, número e o perfil das pessoas, prioritariamente atendidas, pelos projetos

\section{Manifestação Artística: o Teatro de Marionetes.}

O BuZum! segue a mesma trilha dos saltimbancos da idade média, que iam com seus pequenos teatrinhos de cidade em cidade, alegrando adultos e crianças, inventando mundos onde tudo é possível. Esse espaço carrega consigo todo o equipamento teatral necessário para os espetáculos: tem plateia, tem palco, iluminação, sonorização, ar condicionado. É um ônibus, conforme figura acima, que chega à porta das escolas, creches, casas, praças, parques indo de encontro do seu público. A produtora afirma sobre a ideia de "colocar roda no teatro" como a ideia de acesso, a todos os locais, é que move o projeto.

Já ultrapassou o número de 500 mil pessoas atendidas ao longo de todos os anos do projeto, sendo 100 mil somente no último ano. Deste total, 35 trabalham diretamente com o projeto.

Chega às crianças e adolescentes, prioritariamente, onde elas estiverem, segundo a produtora. São sete sessões por dia, com 20 minutos cada, tempo exato para não interromper a dinâmica da escola, a criança sai da sala, entra no "BuZum", assiste ao espetáculo e volta pra sala, tudo isso em menos de 45 minutos, duração média de uma aula. A cada dia um novo lugar, novas escolas, novos públicos.

As apresentações gratuitas, em escolas públicas, aliam o espetáculo do palco com o conteúdo da sala de aula. Além de encantar, transformam o aprendizado em um mundo mágico. O projeto fornece para as escolas material pedagógico, desenvolvido em parceria com o Instituto Saberes, para os educadores trabalharem temas transversais nas aulas. As crianças ganham um pequeno teatro de papel para brincarem e criarem as próprias histórias com seus bonecos e cenários.

Hoje, são 11 peças - a lógica do teatro de marionetes é a mesma, o que muda são os temas de cada peça - em repertório que percorrem o país, rodando 300 mil quilômetros para realizar mais de 9.000 apresentações, em média, para 250 cidades.

Os números tornam o BuZum! um dos maiores projetos itinerantes de teatro infantil do país, estando entre os oitenta produtores que mais captaram recursos, ao longo dos anos, via leis de incentivo fiscais. Em 2014, a companhia conquistou, com a peça Intolerância, os prêmios de Melhor Produção e Melhor Autor de Texto Original, no $1^{\circ}$ Prêmio São Paulo de Incentivo ao Teatro Infantil e Jovem. Em 2015, o BuZum! recebeu o Prêmio Governador do Estado para 
Cultura, na categoria Arte para Crianças - Voto Popular. Também foi contemplado duas vezes, em 2014 e 2016, com o Prêmio Zé Renato de Teatro para cidade de São Paulo.

\subsubsection{Estratégias de Captação}

$\mathrm{Na}$ entrevista, o entrevistado coloca o próprio projeto com a grande estratégia de captação do BuZum: credita ao projeto devido às suas características de solidez, itinerância, gratuidade, ir até às crianças, rodar o país, além de um material de apresentação relevante e visualmente bonito para as empresas patrocinadoras terem suas marcas.

As estratégias gerais de captação são por tipo de fontes de captação. Apesar disto não ter sido explicitado pelo entrevistado claramente, pode-se extrair esta conclusão, ao realizarmos as análises nas respostas da entrevista.

Fonte - Leis de Incentivo para empresas:

1) Estratégias do terceirizado: que prestam serviços de captação nesta área para o BuZum. O BuZum não conhece as estratégias de captação do terceiro, mas acreditam que, por terem uma relação muito próxima dos captadores bem como procurar ter, como captadores, pessoas que tenham sinergia com a causa sociocultural do Buzum, isto por si só já é uma estratégia.

1.1) Reuniões marcadas: Percebe-se, pelas respostas, que os captadores podem vir a marcar reuniões com potenciais patrocinadores, pois o entrevistado fala sobre ir às reuniões, na maioria das vezes. Onde a apresentação do projeto é feita baseada no histórico, na missão e causa, e nos números do Buzum.

2) Busca de empresas: o entrevistado afirmou que no último ano, fez dois movimentos, que o presente trabalho considera importante destacar:

2.1) Lista de empresas que poderiam ser potenciais patrocinadores dos projetos do BuZum e entregou esta lista a um dos 7 captadores de recursos, ao qual o Buzum tem relacionamento mais estreito e nomeou como parceiro ativo.

2.2) Busca ativa por empresas captadoras de recurso através de busca em site, depois ligando por telefone e recebendo visita presencial, na sede do BuZum, para a apresentação do projeto. 
3) Estratégia de busca por editais em internet: não há periodicidade. Mas, após achar algum que o projeto do BuZum se enquadra, há a inscrição como foi com a Lei de Fomento ao Teatro na cidade de São Paulo, o Procultura da Funarte, além do Prêmio Zé Renato de incentivo ao Teatro na cidade de São Paulo, por dois anos.

\section{Fonte-Outros}

4) Acionar escolas ou redes SESC's e SESI ainda sendo um movimento muito tímido, segundo entrevistado.

\subsubsection{Estrutura de Captação}

Ao se considerar as estratégias desenhadas acima, fica evidente que a estrutura de captação é mista, apesar do entrevistado considerar que é terceirizada. Esta é uma evidência da entrevista, na medida, que, aparentemente, o entrevistado associa a captação de recursos apenas e diretamente ligada às fontes de recursos advindas das leis de incentivo, mas é importante concluir-se, das análises da entrevista, que a estrutura pode ser considerada mista por haverem um ou mais indivíduos, dentro do empreendimento, mobilizados na função de obterem recursos, como segue abaixo:

- Interna: ela é composta internamente pela entrevistada, no momento que esta busca editais e fontes, classificada como "outros" acima, para obtenção de recursos.

- Terceirizada: no momento, há mais ou menos sete empresas realizando captação de recursos para os projetos do Buzum, segundo o entrevistado.

Da terceirização, há dois pontos para destacar:

\section{1) Motivo de Terceirizar}

Ao ser perguntada sobre o porquê resolveu terceirizar, o entrevistado responde que a profissão de captação de recursos é algo muito sério, que há a necessidade de ser ter know how para exercê-la. Ela é legitimada, inclusive, pelas leis de incentivo.

2) Controle do trabalho do terceiro:

2.1) Há um controle sobre quais empresas, potenciais patrocinadoras, cada um, destes sete terceiros, estão em contato, que é feito via planilha de Excel.

2.2) A formalização de que estas empresas terceiras podem representar o projeto BuZum é feita por e-mail. 


\subsubsection{Fontes de Captação}

O projeto já contou com o recurso das seguintes fontes:

- Leis de Incentivo - doações de pessoas jurídicas, prioritariamente: Leis de incentivo à cultura, como a Rouanet, do governo federal, o Programa de Ação Cultural (ProAC), do governo de São Paulo.

- Editais: Lei de Fomento ao Teatro na cidade de São Paulo, o Procultura da Funarte.

- Prêmio: como o Zé Renato de incentivo ao Tetro na cidade de São Paulo.

- Prestação de serviços tais como venda de espetáculos para escolas.

- Prestação de serviços tais como venda de espetáculos para SESC's e SESI.

- Outros.

No último ano, a divisão de receita foi praticamente 90\% Lei Rouanet, $8 \%$ ProAC e os outros $2 \%$ com outros.

Um ponto importante, colocado pelo entrevistado, é que o BuZum nasceu junto com as leis de incentivo e que sempre teve um grande patrocinador, via lei de incentivo federal, principalmente.

Resumidamente, poderíamos considerar o empreendimento BuZum como sociocultural, com 35 pessoas trabalhando diretamente em seus projetos. Estes projetos são socioculturais e impactaram 100 mil pessoas, no último ano, com uma receita de R\$1,5milhões. Esta receita sustentou o empreendimento, no último ano, com:

- $\quad$ Fontes de captação sendo prioritariamente os recursos fiscais de incentivo - de pessoas jurídicas.

- $\quad$ Estrutura de captação mista: esta estrutura não é dita, definida e nem nomeada claramente pelo entrevistado, mas para fins do trabalho, podemos considerar que a estrutura é mista por haver uma pessoa interna, que cuida da busca por editais e prestações de serviço e por haverem sete empresas terceirizadas, que captam recursos, via leis de incentivo.

- $\quad$ Estratégias de captação: estas estratégias não são ditas, nem definidas numa ordem sistêmica e organizada, durante a entrevista, mas ao realizarmos as análises das respostas, podemos deduzir que as estratégias existem e são divididas por tipo de fontes de captação a serem acionado, embora estas não estejam organizadas sistemicamente. 


\subsection{ImageMagica}

"Perceber o mundo em que se vive é o primeiro passo para modificá-lo." (Andre Francois, sócio - fundador da ImageMagica)

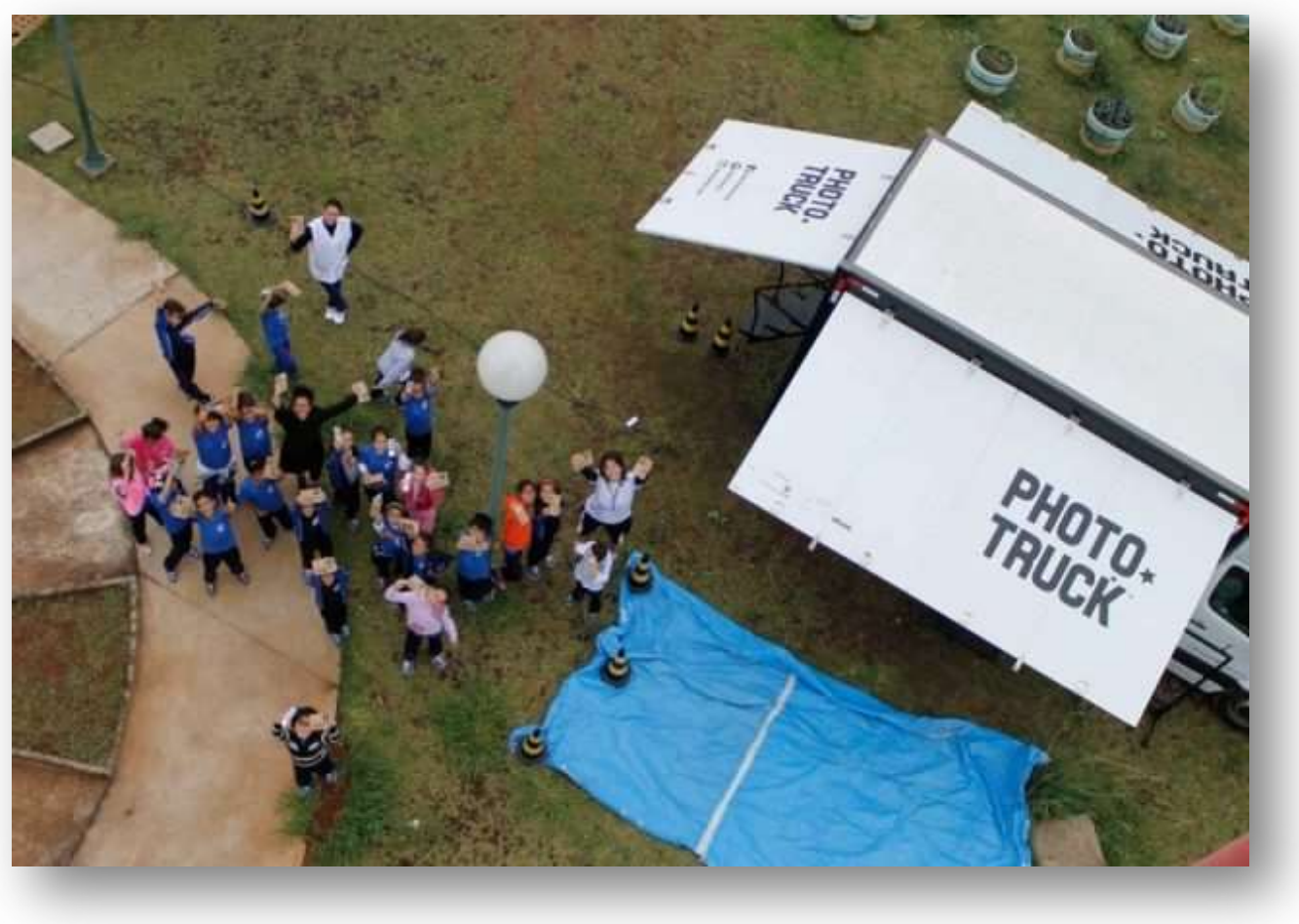

Figura 4 - PhotoTruck (Fonte: sb24horas.com.br/)

\subsubsection{Características do empreendimento}

Quem são, histórico, tipo de natureza jurídica, faturamento, tempo de existência

Este empreendimento é uma organização da sociedade civil de interesse público, com dezenove anos de existência formal e vinte e cinco anos de história.

Nasceu da iniciativa do fotógrafo paulistano André François. Unindo fotografia e questões sociais, a organização acredita que a imagem é uma linguagem universal com o poder de transpor barreiras e atuar como uma ferramenta de mudanças e transformação social. A missão da ImageMagica, segundo a entrevistada, é transformar as pessoas através da fotografia, dando essa ferramenta de percepção para empoderar cada cidadão, mulher, homem, criança, independente da sua condição social, empoderar para que ele seja autor da sua própria história. 
Atualmente, a organização tem uma receita média de $\mathrm{R} \$ 2,5$ milhões, que segundo o entrevistador, sustenta a organização financeiramente, a entrevistada cita as palavras "mal", mas "conseguimos".

\subsubsection{Projetos socioculturais}

Suas manifestações artísticas, número e o perfil das pessoas, prioritariamente atendidas, pelos projetos

\section{Manifestação Artística: a Fotografia.}

Os projetos da ImageMagica atuam em dois pilares: De um lado, programas sociais desenvolvidos em hospitais, escolas e comunidades no Brasil e no mundo, os projetos convidam crianças, adolescentes, pacientes e profissionais de saúde a fotografar, refletir sobre sua realidade e propor transformações. Além do impacto nas comunidades e instituições, os próprios participantes multiplicam o saber fotográfico e realizam exposições com as imagens produzidas no local. Com o PhotoTruck, unidade móvel feita sob medida para os projetos educacionais, os projetos têm alcançado cada vez mais pessoas por meio de oficinas itinerantes.

Do outro, documentários fotográficos: produzidos em sua maioria por André François e sua equipe, os documentários pautam temas de interesse público, como saúde, educação e meio ambiente. Transpondo os limites do território nacional, os projetos ganharam o mundo, incluindo viagens a países como Camboja, Haiti, Japão, Bolívia, Ruanda, China, Estados Unidos e Quênia. Com o apoio de instituições como Organização Mundial da Saúde (OMS), ONU e Médicos Sem Fronteiras (MSF), os resultados são devolvidos para as comunidades e espalhados para outros lugares por meio de livros, exposições, palestras, vídeos e sites.

São atendidas 30 mil pessoas por ano, em todo o país e há 22 pessoas trabalhando para os projetos do empreendimento, sendo 12 fixos e 10 com contratos temporários. Sendo as pessoas atendidas, de todas as faixas etárias e prioritariamente em situação de vulnerabilidade social - lê-se aqui vulnerabilidade como pertencentes às classes econômicas menos favorecidas do Brasil ou com limitações geográficas para ter acesso a formações em fotografias, segundo o projeto. Por ano, há, em média, 10 projetos diferentes acontecendo nestes dois eixos acima.

A ImageMagica tem parceria e reconhecimento da ONU pelo trabalho realizado em comunidades carentes com a fotografia, além da OMS. 


\subsubsection{Estratégias de Captação}

O que chama a atenção nas análises das respostas desta entrevista é que ao ser perguntada sobre as estratégias de captação e o período em que elas são traçadas, há clareza na resposta bem como na forma como descreve como as ações são planejadas.

Antes de se traçar as estratégicas de captação, a organização faz um planejamento orçamentário para fazer a sua causa social acontecer pelo período de um ano. Este planejamento, ao qual a entrevistada, nomeia de "parada do início do ano" traz o "bugdet"22 necessário para que a organização busque os recursos necessários. Logo, podemos organizar as análises das respostas, como abaixo:

- Há uma área responsável pelas estratégias: o Núcleo de Desenvolvimento Institucional é o nome da área responsável por pensar e executar as estratégias para se alcançar o bugdet definido, no início do ano.

- Periodicidade ao revisitar o plano estratégico do ano: reuniões periódicas ocorrem entre a entrevista, uma das sócias da organização, com a equipe do Núcleo.

- A entrevistada e o fundador têm reuniões para pensarem o rumo da organização, a longo prazo - próximos 5 anos.

- Estratégias executadas pela Estrutura Interna:

1) Consulta diária na base do Ministério da Cultura, Secretaria de Cultura e busca por editais: para obtenção de dados de investimento de empresas por tipo de projetos. A organização utiliza estes dados para alimentar o sistema de controle interno deles, criar uma lista e acionar esta lista de empresas.

2) Listas acionadas por telefone, principalmente, com o objetivo de marcar reunião presencial. A entrevistada diz que, por experiência prática, e-mails não funcionam tanto.

\section{3) Reunião Marcada}

3) Discurso: Ênfase para o histórico da organização, suas parcerias de longo prazo com a ONU e OMS são os principais pontos fortes do discurso.

- Estratégia executada pelas empresas terceiras: a ImageMagica não tem conhecimento. Mas, mantém relacionamento frequente por e-mail com estes parceiros, afim de se atualizarem dos possíveis patrocinadores.

\footnotetext{
22 Termo para se fazer referência à orçamento em inglês.
} 
Outro ponto a se destacar é que o empreendimento procura estabelecer relacionamento frequente com o patrocinador e com o terceirizado, quando é este quem consegue o patrocínio, buscando a manutenção do relacionamento, bem como a renovação posterior deste.

\subsubsection{Estrutura de Captação}

A estrutura dedicada à captação é mista:

- Interna: A estrutura é bem definida e inclusive é nomeada como responsabilidade do Núcleo de Desenvolvimento Institucional da ImageMagica. A entrevistada explica que, no começo da organização, essa captação não era estruturada em um núcleo, ela era feita por membros da equipe de maneira mais orgânica e menos estruturada, a partir de 2006, a organização assumiu esse formato, onde esse núcleo se tornou o responsável por fazer as captações.

- Terceirizada: A organização conta com 4 empresas terceiras, que ela nomeia, segundo a entrevista, de parceiros. Estes parceiros buscarão recursos para alguns projetos específicos da organização. Eles estão na ImageMagica, pois a organização entendeu um pouco da história e missão deles e se identificou. A entrevistada, afirma que não tem muitos parceiros para a captação, mas tem parceiros com os quais trabalha, há algum tempo.

Da terceirização, há dois pontos para destacar:

1) Motivo de Terceirizar: A terceirização vem no sentido de aumentar a abrangência de captação da organização.

2) Controle do trabalho do terceiro: A organização usa um sistema chamado Asana, que é um sistema de organização de projetos, onde se cadastra todo mundo e, cada empresa que esse parceiro pede para realizar a captação de recursos, é colocada no sistema, afim de evitar que duas empresas falem com o mesmo potencial patrocinador. A partir desse sistema, a ImageMagica organiza seus relacionamentos.

\subsubsection{Fontes de Captação}

O projeto vive, em sua totalidade, dos recursos advindos da fonte Leis de Incentivo pessoas jurídicas. As leis são diversas e não somente as estritamente vinculadas à cultura, tais como:

- Lei Rouanet

- ProAC 
- Programa Nacional de Apoio à Atenção Oncológica (PRONON)

- Programa Nacional de Apoio à Atenção da Saúde da Pessoa com Deficiência (PRONAS/PCD)

- Fundo da Criança e do Adolescente (FUMCAD)

Um ponto importante, colocado pelo entrevistado, é que a ImageMagica sempre teve maior participação das leis de incentivo como fontes de recursos, embora, no passado, já tenha sido $80 \%$ leis e os outros $20 \%$ prestação de serviços. Atualmente, a organização tem uma linha de prestação de serviços, por exemplos nas escolas, com oficinas para as escolas e um dos focos do Núcleo de Desenvolvimento Institucional é ter projetos independentes das leis de incentivo.

Resumidamente, poderíamos considerar o empreendimento ImageMagica como sociocultural, com 22 pessoas trabalhando diretamente em seus projetos. Estes projetos são socioculturais e impactaram 30 mil pessoas, no último ano, com uma receita de R \$2,5milhões. Esta receita sustentou o empreendimento, no último ano, com:

- $\quad$ Fontes de captação: na totalidade, são as leis de incentivo - doações de pessoas jurídicas.

Estrutura de captação mista: esta estrutura é bem definida, com funções claras. Há uma área interna dedicada somente a esta função, bem como há o complemento da terceirização para alguns projetos específicos que a organização precisa obter recursos. Esta terceirização conta com 4 empresas, na totalidade.

- $\quad$ Estratégias de captação: também são estratégias bem definidas e executadas pela área interna, responsável pela captação de recursos. As estratégias buscam recursos para os projetos da organização, mas mostram em suas apresentações para obtenção de recursos o quanto a ImageMagica tem história e credibilidade, devido às parcerias de reconhecimento do trabalho como a ONU e a OMS. As estratégias são desenhadas desde a coleta de dados até o meio e as ferramentas utilizadas para obtenção de recurso, tais como telefone, reunião presencial e por fim, uma apresentação robusta. 


\subsection{Doutores da Alegria}

"A arte como mínimo social, ou seja, como uma das necessidades básicas para o desenvolvimento digno do ser humano, assim como alimentação, saúde, moradia e educação."

(Tarefa Institucional do Doutores)

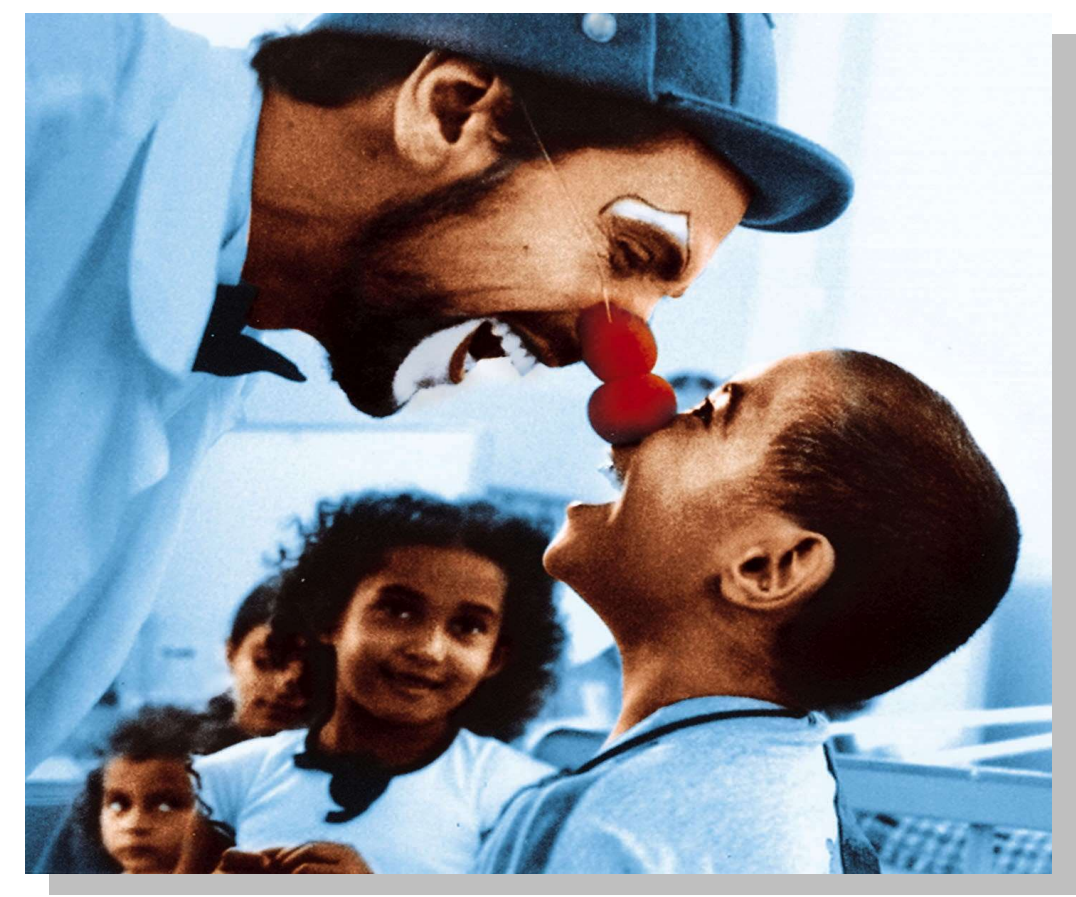

Figura 5 - Artista do Doutores da Alegria em atuação em hospital

(Fonte: Material Institucional da Organização Doutores da Alegria)

\subsubsection{Características do empreendimento}

Quem são, histórico, tipo de natureza jurídica, faturamento, tempo de existência

Segundo o material institucional da organização, a entidade Doutores da Alegria é uma organização da sociedade civil sem fins lucrativos que, desde 1991, utiliza a arte do palhaço para intervir junto a crianças, adolescentes e outros públicos em situação de vulnerabilidade e risco social em hospitais públicos e ambientes adversos, por esta razão é considerado um empreendimento elegível de análise na pesquisa.

Desde 2016, define uma tarefa institucional que propõe a arte como mínimo social considerando este mínimo parte das necessidades básicas para o desenvolvimento digno do ser humano, assim como alimentação, saúde, moradia e educação. 
A organização teve receita de $\mathrm{R}$ \$ 8,9 milhões, no último ano, que segundo a entrevistada permite ao Doutores se sustentarem e continuarem suas atividades.

O Doutores, além de mais de 20 prêmios recebidos por reconhecimento ao trabalho sociocultural, ele tem chancelas para atuação dos seguintes órgãos:

- Utilidade Pública Municipal

- Utilidade Pública Estadual

○ $\quad$ Utilidade Pública Federal

○ Inscrição no Conselho Municipal de Assistência Social (COMAS)

- Inscrição no Conselho Municipal dos Direitos da Criança e do Adolescente de São Paulo (CMDCA)

- Certificação de Entidade de Assistência Social do CNAS.

\subsubsection{Projetos socioculturais}

Suas manifestações artísticas, número e o perfil das pessoas, prioritariamente atendidas, pelos projetos.

\section{Manifestação Artística: Teatro, com ênfase para Arte do Palhaço.}

São 26 anos de existência, atuando em 18 hospitais públicos distribuídos por São Paulo, Rio de Janeiro e Recife com certificação de utilidade pública, inscrição no Conselho Municipal de Assistência Social, inscrição no Conselho Municipal da Criança e do Adolescente de São Paulo, certificação de Entidades Beneficentes de Assistência Social e certificação de Tecnologia Social pela Fundação Banco do Brasil.

Além disto, o grupo Doutores inspira mais de mil iniciativas semelhantes pelo país e oferece a arte do palhaço como profissão para centenas de jovens.

Ao longo dos 26 anos de atividade, foram:

105.094 visitas em hospitais de São Paulo

63.443 visitas em hospitais de Recife

14.850 pessoas impactadas no Rio de Janeiro

Nos hospitais, a organização entende que pode promover o acesso à arte e a mudança de visão hospitalar: o lugar de exercer a saúde de uma comunidade e não o lugar para tratar doença.

A organização também promove formação de palhaços, cursos e vivências, sendo:

25 jovens em processo de formação;

213 pessoas impactadas por cursos; 
660 participantes de palestras e vivências pela Escola, sustentada pela entidade Doutores da Alegria.

Há também, 1905 grupos independentes de pessoas, que utilizam a figura do palhaço para atuarem nos hospitais, participando do Programa Palhaços em Rede, promovido pelo grupo, para compartilhar práticas de palhaço e ajudar na formação destes.

Doutores também tem espetáculos teatrais, em seu repertório, são no mínimo 12 trabalhos teatrais em voga, segundo site institucional do empreendimento.

Além de inúmeros prêmios de reconhecimento devido aos projetos que executa e ao trabalho que a organização, na totalidade, exerce no Brasil.

No último ano, foram 167 mil pessoas beneficiadas direta e indiretamente pelos projetos do Doutores, sendo, prioritariamente, pessoas em situação de vulnerabilidade social acrescidas da situação adversa de hospital.

\subsubsection{Estratégias de Captação}

Há muitas estratégias de captação que são realizadas pela organização. As listadas abaixo foram são fruto das elencadas na entrevista somadas à observação direta da autora do trabalho:

- Há uma estratégia anual, que gera uma régua de ações, mês a mês, como algumas citadas abaixo, pela entrevistada:

- Compra de alguns mailings que ajudam a fortalecer a estratégia, a divulgar o projeto para um maior número de pessoas

○ Participação muito forte nas redes sociais

- Ainda alguns eventos voltados para o nosso prospect, para essas empresas que estão conhecendo o projeto

- Convite para que o prospect conheça o trabalho nos hospitais

$\circ \quad$ Envio de e-mail marketing para marcar reuniões presenciais

○ Telefonemas para marcar reuniões presenciais

Essa estratégia é elaborada anualmente, sempre no início do ano. Geralmente, se segue a estratégia, com o cumprimento de agenda dos eventos, dos disparos dos e-mails, dos posts em redes sociais, em 2016, como estratégia de captação de recurso, houve um baile e um jantar de gala, comemorando os 25 anos da organização, que não estava planejado inicialmente, e que ajudou a compor a receita de 2016.

Destas ações apresentadas acima, a pesquisadora já foi impactada com: 
- Campanhas de Doação feitas em todas as redes sociais

- Botão Doe no site institucional do Doutores

- Campanhas de Como Doar, nos materiais institucionais, inclusive Balanço, passando as seguintes mensagens simples e diretas de como cada pessoa pode doar:

$\begin{array}{ll}\circ & \text { Fazer uma doação única ou tornar-se sócio mantenedor } \\ \circ & \text { Doar imposto de renda } \\ \circ & \text { Doar pontos de milhagens } \\ \circ & \text { Fazer um curso } \\ \circ & \text { Presentear com doação } \\ \circ & \text { Sua empresa Patrocinar via leis de incentivo ou recursos próprios } \\ \circ & \text { Fazer uma doação } \\ \circ & \text { Contratar intervenções e palestras } \\ \circ & \text { Fazer licenciamento de marca } \\ \circ & \text { Apoiar institucionalmente } \\ \circ & \text { Fazer uma campanha de marketing }\end{array}$

\subsubsection{Estrutura de Captação}

A estrutura dedicada à captação é mista:

- Interna: A estrutura é bem definida e enxuta, segundo a entrevistada, contando com 2 pessoas dividas por tipo de fontes de captação pessoa física e pessoa jurídica. Além destas duas pessoas, há uma unidade de negócios, que compõem a receita do Doutores, dedicadas à prestação de serviços, vendendo palestras, cursos, fechando peças.

- Terceirizada: A organização tem de 10 a 12 empresas terceiras, que ela nomeia, segundo a entrevistada, de consultoria. Estes parceiros são selecionados, segundo dados colhidos na entrevista, após uma boa conversa para alinhar expectativas.

Da terceirização, há dois pontos para destacar:

1) Controle do trabalho do terceiro: A organização tem um contrato formal de trabalho com o terceiro, onde as empresas as quais ele representa o Doutores está nomeada.

2) Necessidade de relacionamento e aproximação do trabalho: a entrevista cita que o Doutores está revendo o papel do terceiro junto à organização afim de que estes terceiros conheçam mais sobre o trabalho do Doutores, estejam mais próximos. 
A entrevistada conta que a estrutura interna, com funções bem definidas, é recente, na percepção dela, e existe desde 2004. O Doutores já teve muitas experiências, nos dez primeiros anos de existência, era realizada por terceiros, não existindo uma equipe própria que ajudasse a trazer a receita da organização.

\subsubsection{Fontes de Captação}

As fontes de recursos do Doutores são diversas, como veremos a seguir, ao ser perguntada sobre a composição percentual entre as fontes ter sido sempre assim ou não, a entrevistada afirmou que há quatro anos, o percentual de leis de incentivo era de $51 \%$ e que vem crescendo devido à instituição ser idônea frente a todas as especulações que se têm sobre a Lei Rouanet, principalmente.

Seguem fontes de recurso do empreendimento, bem como seus percentuais de participação:

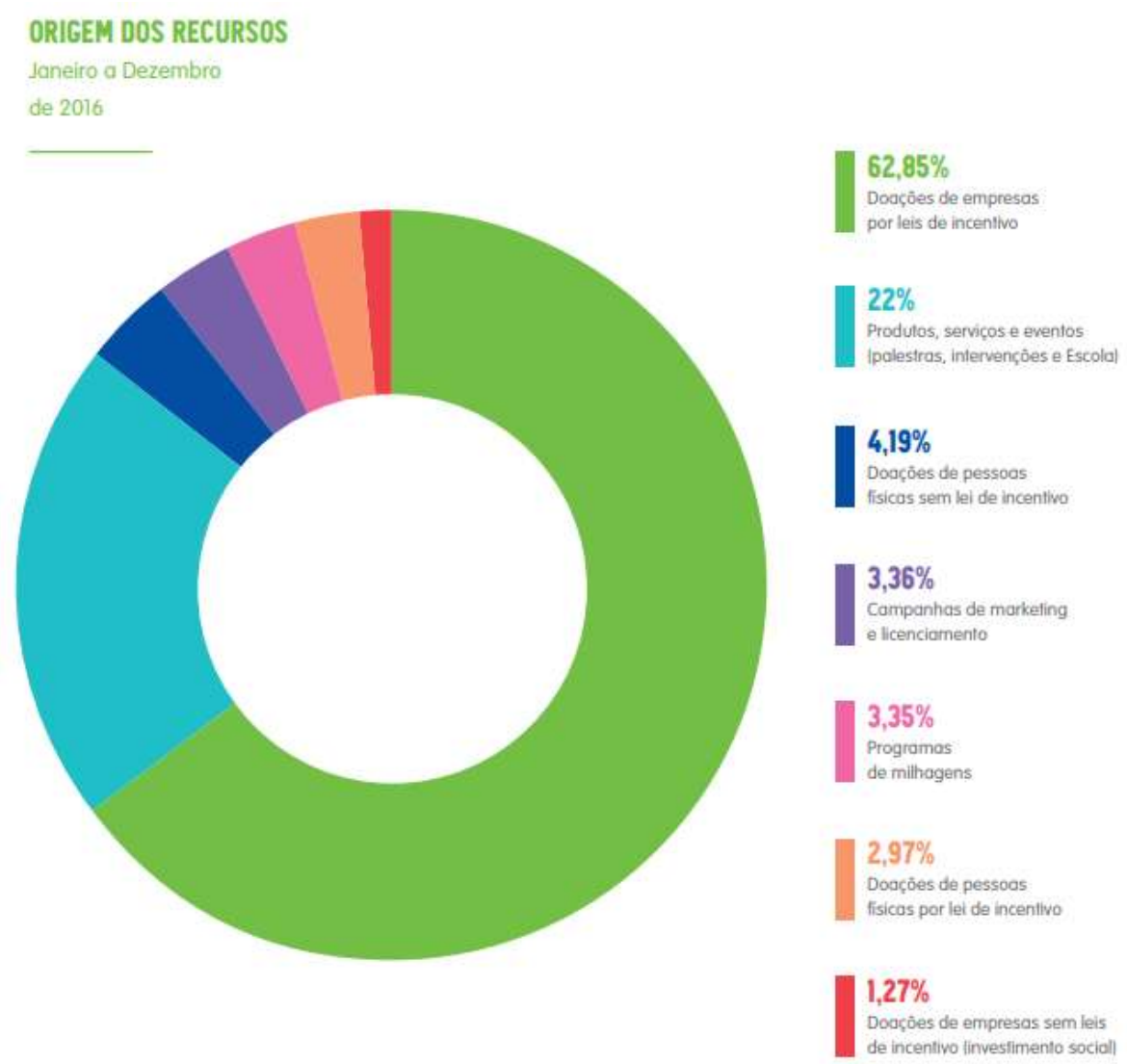

Figura 6 - Fontes de Recursos Doutores da Alegria (Fonte: Balanço 2016 Doutores da Alegria)

Um fato relevante na organização é que desde 2015, a organização efetuou mudanças em sua missão, que era algo como "levar a alegria a ocasiões de adversidade, criando relações 
saudáveis", por uma tarefa institucional que propõe "a arte como mínimo social”, intitulando-a tarefa institucional, pois o termo missão, segundo o entrevistado, remetia a algo "militar". E a mudança do que se busca, através desta tarefa, é, segundo o entrevistado e o próprio material do balanço dos 25 anos da instituição, vinculada ao amadurecimento organizacional do grupo. A organização percebeu, ao longo dos últimos anos, que a razão de sua existência está intimamente vinculada à arte e ao social. Isto se reflete, inclusive, nas fontes de recursos que garantem a sustentabilidade financeira e econômica da organização: as leis de incentivo têm como objeto a cultura e geralmente estão associadas a investimentos sociais das empresas.

Resumidamente, poderíamos considerar o empreendimento Doutores da Alegria como sociocultural, com mais de 70 pessoas trabalhando diretamente em seus projetos. Estes projetos são socioculturais e impactaram 167 mil pessoas, no último ano, com uma receita de R $\$ 8,9$ milhões. Esta receita sustentou o empreendimento, no último ano, com:

- $\quad$ Fontes de captação: divididas entre $62,85 \%$ leis de incentivo pessoa jurídica, $22 \%$ produtos e serviços, 4,19\% doações de pessoas físicas sem lei de incentivo, 3,36\% campanhas de marketing e licenciamento, 3,35\% programas de milhagens, 2,97\% doações de pessoas físicas com lei de incentivo, 1,27\% pessoa jurídica sem lei de incentivo.

Estrutura de captação mista: esta estrutura é bem definida, com funções claras. Há uma área interna dedicada somente a captação de pessoa física e jurídica e uma unidade de negócios dedicada à prestação de serviços; há o complemento da terceirização. Esta terceirização conta com de 10 a 12 empresas, na totalidade.

- $\quad$ Estratégias de captação: também são estratégias bem definidas e executadas pela área interna, responsável pela captação de recursos e pela unidade de negócio. As estratégias são das mais variadas formas e para atingir as mais diferentes fontes. Há uma régua de ações bem planejada para cada mês do ano. Esta organização já impactou a pesquisadora em redes sociais, através de suas ações em prol da busca de recursos. 


\subsection{Ibirajá Produtora Artística}

"Uma empresa movida pelo amor e dedicação à cultura."

(Frase extraída do site do empreendimento)

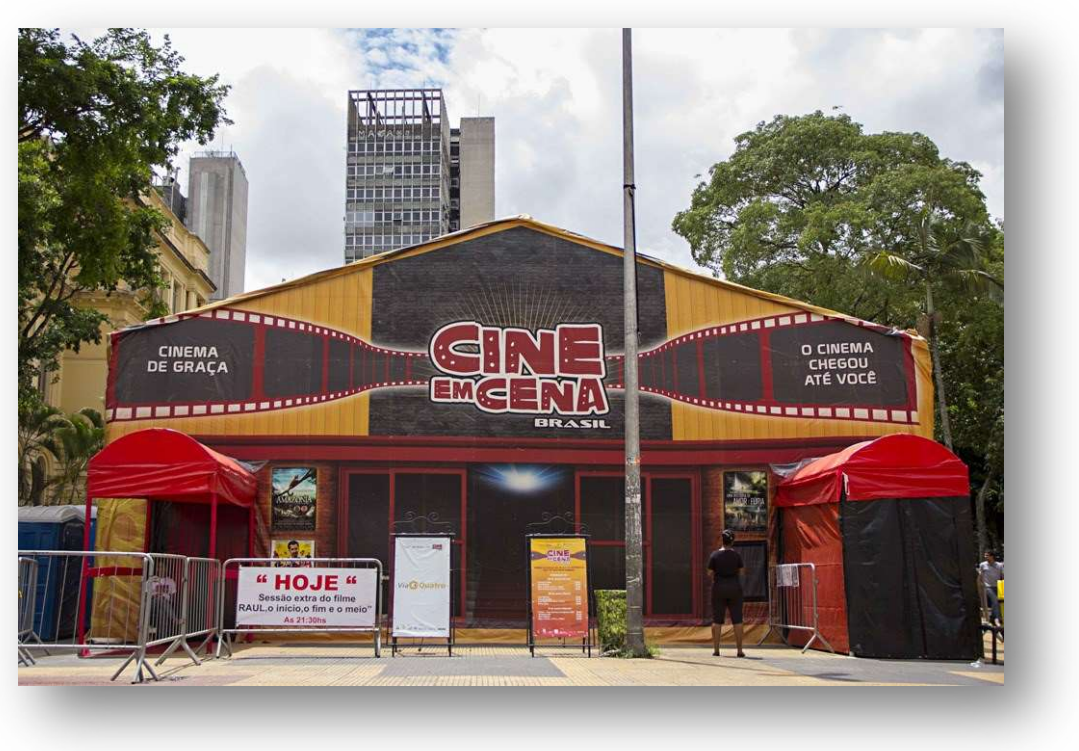

Figura 7 - Projeto Cine em Cena (Fonte: Arquivo do Projeto)

\subsubsection{Características do empreendimento}

Quem são, histórico, tipo de natureza jurídica, faturamento, tempo de existência

A Ibirajá é uma empresa, que existe há cinco anos, mas que tem seus projetos de cinema existindo, através de outro CNPJ, há 20 anos, tendo como foco a realização de eventos culturais, em especial projetos ligados ao cinema.

Fundada por dois sócios apaixonados pelo assunto, a Ibirajá reúne neles sua expertise. Juntos, Edson Souza e José Carlos reúnem mais de 20 anos de experiência nesse segmento. O projeto de cinema itinerante existia inicialmente ligado à cineasta Lais Bodanzky, famosa nacionalmente pelo filme premiado Bicho de Sete Cabeças.

Sobre o faturamento da empresa: o entrevistado preferiu não passar estes dados. 


\subsubsection{Projetos socioculturais}

Suas manifestações artísticas, número e o perfil das pessoas, prioritariamente atendidas, pelos projetos

\section{Manifestação Artística: Cinema.}

Entre os projetos assinados pela Ibirajá, estão o Cine em Cena Brasil e Cine em Cena no Ar, que percorrem o Brasil levando o cinema para as regiões mais afastadas e de difícil acesso à cultura nacional, promovendo assim a democratização e a divulgação de nosso cinema, com tendas montadas a céu aberto.

São 57 cidades visitadas, ao longo de existência do projeto, com 66 mil espectadores e 60 filmes nacionais e internacionais promovidos e circulados ao público de crianças, adolescentes e adultos. Mas, hoje, o foco principal são crianças em escolas públicas, sendo o filme apresentado e utilizado como ferramenta de discussão em sala de aula. Há 12 pessoas trabalhando diretamente com o projeto.

\subsubsection{Estratégias de Captação}

As estratégias de captação, até dois anos atrás, não existiam praticamente, pois a Ibirajá tinha seus projetos patrocinadores integralmente por uma empresa e isto bastava para os resultados sociais e financeiros do empreendimento. Desde 2015, passou a ser necessário o advento de mais recursos e então, a Ibirajá buscou terceirizados para esta ajuda além de se inscrever em festivais e buscar por empresas que quisessem eventos de cinema.

Para apresentarem-se a estas empresas, o empreendimento se prepara com uma apresentação do projeto e procura ir em reuniões presenciais tanto com o terceiro quanto com outras fontes de recursos.

Pela análise de dados, podemos categorizar, da seguinte forma:

- Estratégias desenvolvidas pela Ibirajá, baseadas na contingência necessária, de dois anos para cá, foram de:

- Busca de terceirizados, apresentando ao projeto.

- Busca de empresas interessadas na região Nordeste - por ser uma região pouco atendida com relação ao cinema.

- Busca de empresas para realização de eventos de cinema pagos.

- Estratégias do terceirizado: não são conhecidas pelo empreendimento. 


\subsubsection{Estrutura de Captação}

É importante salientar que, apesar disto não ter sido dito de forma bem definida, na entrevista, pode-se concluir, por análise das respostas, que a estrutura pode ser considerada mista por haverem um ou mais indivíduos, dentro do empreendimento, mobilizados na função de obterem recursos, como segue abaixo:

- Interna: ela é composta internamente pelo entrevistado e seu sócio, no momento que estes buscam eventos ou empresas na região nordeste do Brasil, para obtenção de recursos.

- Terceirizada: no momento, há mais ou menos cinco empresas realizando captação de recursos para os projetos da Ibirajá, segundo o entrevistado.

Da terceirização, há dois pontos para destacar:

1) Motivo de Terceirizar

Ao ser perguntada sobre o porquê resolveu terceirizar, o entrevistado responde que o projeto nasceu desta maneira.

2) Controle do trabalho do terceiro:

2.1) Há um controle sobre quais empresas, potenciais patrocinadoras, cada um, destes terceiros, estão em contato, que é feito via e-mail e telefone.

2.2) A formalização de que estas empresas terceiras podem representar o projeto é feita por e-mail.

\subsubsection{Fontes de Captação}

As fontes de recursos as quais o projeto faz uso estão em torno de:

- Leis de Incentivo - pessoas jurídicas, sendo $80 \%$ desta fonte

- Editais com 5\%

- Prestação de serviços em eventos 10 a $15 \%$

- Festivais ou mostras de cinema: 0 a $5 \%$

Ao ser perguntado se sempre foi esta a divisão, o entrevistado afirma que não: Nos 2 primeiros anos, foi praticamente $100 \%$ lei de incentivo. Do terceiro para o quarto ano, iniciaram trabalhos como os eventos diretos com empresas, à parte das leis de incentivo. O entrevistado afirma que para o empreendimento se sustentar é necessário, além das leis de incentivo, promover estes eventos pagos com verba direta para sustentar o empreendimento. 
Resumidamente, poderíamos considerar o empreendimento Ibirajá como sociocultural, com 12 pessoas trabalhando diretamente em seus projetos. Estes projetos são socioculturais e impactaram 66 mil pessoas, ao longo dos 4 anos. A receita adquirida pelo empreendimento sustenta-o parcialmente, no último ano, com:

- Fontes de captação: a maior porcentagem de participação das fontes é de recursos incentivados por empresas privadas, representando $80 \%$ da totalidade da receita. Seguido pelas prestações de serviço, festivais e editais.

- Estrutura de captação mista: esta estrutura, apesar de pouco definida, é composta internamente por duas pessoas, que buscam por clientes para prestações de serviços e terceirizada com outras cinco empresas exercendo a captação.

- Estratégias de captação: as estratégias passaram a existir de dois anos para cá e são realizadas de forma tímida até o momento. 


\subsection{Pia Fraus Produtora Teatral}

“A não-linearidade, o pouco uso da palavra, a força nas imagens, a relação boneco-ator são os elementos que caracterizam os trabalhos

da companhia."

(Frase extraída do site da produtora)

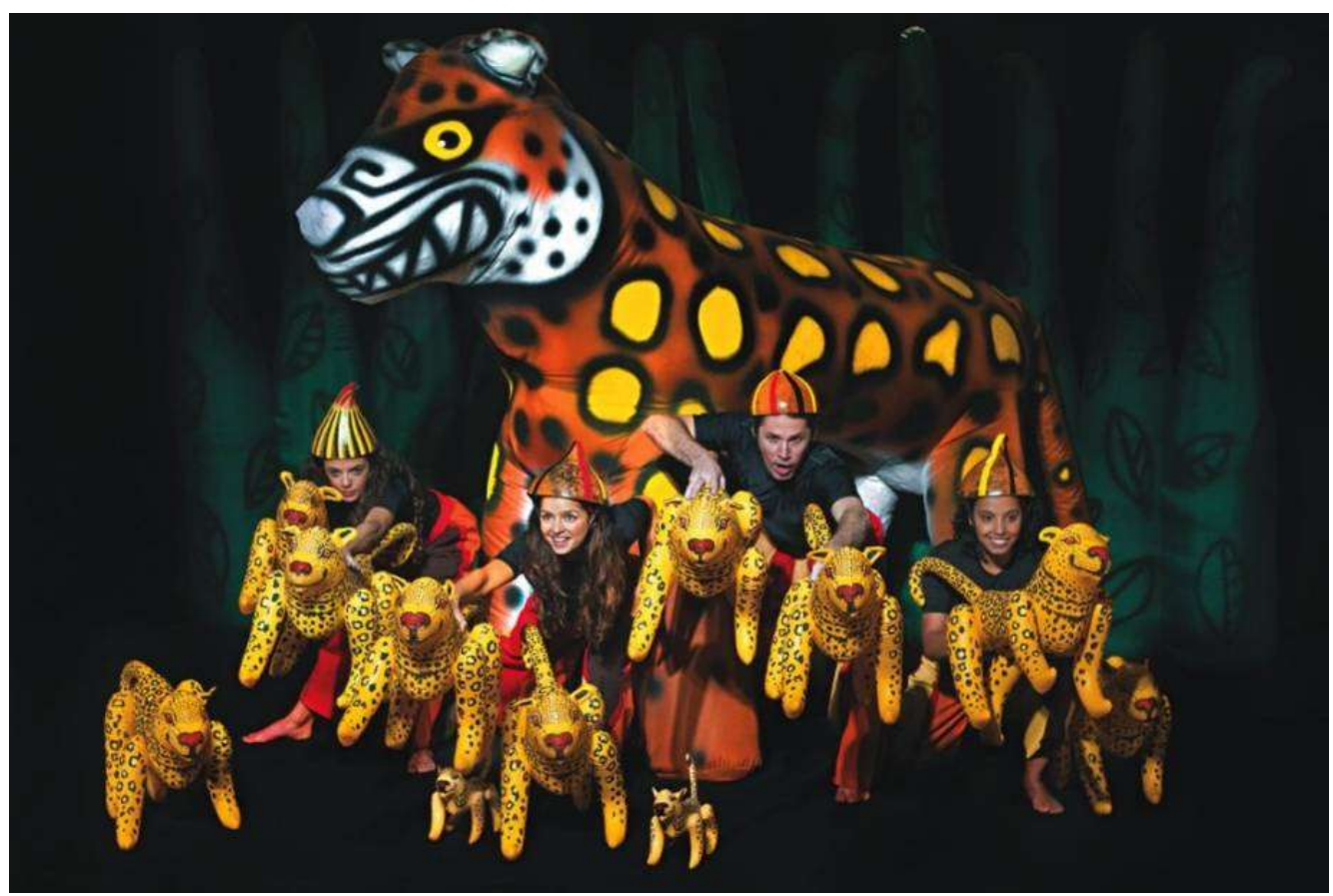

Figura 8 - Projeto Bichos do Brasil (Fonte: Revista Veja São Paulo)

\subsubsection{Características do empreendimento}

Quem são, histórico, tipo de natureza jurídica, faturamento, tempo de existência

Há 35 anos, a Pia Fraus é uma empresa e foi fundada por Beto Andreatta. A companhia já produziu dezenas de espetáculos, apresentando-se em 24 países diferentes nos principais festivais nacionais e internacionais de teatro.

Com a diversidade de formação de seus componentes (teatro, dança, teatro de bonecos e de máscaras, circo e artes plásticas) surgiu a linha de trabalho da companhia: desenvolver uma linguagem que aprimorasse dramaticamente cada uma destas áreas e as integrasse, consolidando um repertório com características muito particulares, buscando o 
aprofundamento, pesquisa e a integração dos recursos do teatro de animação aos de outras linguagens.

O fundador da companhia crê que a Pia Fraus é também sociocultural, dado que existem projetos atendendo a um mercado que tem acesso tanto financeiro quanto geográfico ao espetáculo, mas grande parte dos espetáculos que o empreendimento faz por ano, são voltados para lugares muito populares, muitos distantes, onde as vezes a companhia é o único recurso teatral que as pessoas têm acesso.

A empresa faturou, no último ano, $\mathrm{R} \$ 900 \mathrm{mil}$. Este valor, segundo o entrevistado, serviu para cobrir todas as despesas e custos da companhia.

\subsubsection{Projetos socioculturais}

Suas manifestações artísticas, número e o perfil das pessoas, prioritariamente atendidas, pelos projetos

\section{Manifestação Artística: Teatro de Bonecos.}

Hoje o grupo possui em seu repertório ativos os seguintes projetos:

- 07 à 10 espetáculos, como por exemplo: "Bichos do Brasil", "Círculo das Baleias", "Gigantes de Ar", "Filhotes da Amazônia", a remontagem de "O Vaqueiro e o Bicho Froxo", "A última árvore" e o novo espetáculo "Bichos Vermelhos". No último ano, foram contabilizadas 180 apresentações teatrais.

- Curso de Formação para 35 pessoas em teatros de bonecos.

- O espaço Pia Fraus aberto para contar a história do teatro de bonecos, no Brasil a quem vai visitar.

Com os espetáculos, a Pia Fraus já visitou: Argentina, Uruguai, Colômbia, Chile, Bolívia, Estados Unidos, Espanha, Portugal, Itália, Suécia, Suiça, França, Inglaterra, Escócia, Índia, Timor Leste, Eslovênia, Holanda, Equador, Bélgica, Venezuela, Rússia, República Tcheca e todos os estados brasileiros.

O grupo hoje se dedica, prioritariamente, a apresentações gratuitas para crianças e adolescentes em situação de vulnerabilidade social, bem como apresentações pagas ao público para sustentabilidade da companhia e aluguel do espaço para festas infantis.

O número de pessoas impactadas pelos projetos da companhia ultrapassam a barreira dos milhões, não tendo sido contabilizado desde o princípio da organização e há, em média, 40 pessoas trabalhando diretamente com projetos da companhia. 


\subsubsection{Estratégias de Captação}

Nas análises das respostas, verifica-se que, ao ser questionado sobre as estratégias de captação, o entrevistado remonta a reuniões, que tem com seu sócio, para definição de rumos e para o planejamento orçamentário, que a organização realiza anualmente. Nesta reunião, são discutidas e definidas as ações necessárias para se atingir o orçamento anual.

Desta conversa, há algumas estratégias adotadas:

- Envio de e-mail para redes SESC

- Pesquisas por editais

- Envio de e-mail para festivais

- Envio de projetos incentivados para os captadores.

- Criação de projetos adaptados com a linguagem Pia Fraus e das empresas: com conteúdo que a Pia Fraus acredita, mas percebendo a tendência de mercado e o poder das empresas, segundo o entrevistado, para desenvolverem os produtos - nomenclatura dada pelo entrevistado para os projetos culturais.

A estratégia do terceirizado não é conhecida pelo empreendimento.

\subsubsection{Estrutura de Captação}

A estrutura de captação é mista, considerando-se que há uma ou duas pessoas da companhia em contato com fontes de captação e também há os captadores de recursos terceirizados - que realizam a busca por recursos nas empresas, via incentivos fiscais.

- Interna: para busca de fontes de recursos, tais como festivais, prestações de serviços, vendas de espetáculo.

- Terceirizada: no momento, há mais ou menos oito ou nove empresas realizando captação de recursos para os projetos, segundo o entrevistado.

Da terceirização, há dois pontos para destacar:

1) Motivo de Terceirizar: segundo o entrevistado, a Pia Fraus não resolveu terceirizar, as "coisas" se apresentaram dessa maneira para a companhia, e ela nunca tentou ocupar esse lugar de captador. Para chegar a esta conclusão, o entrevistado fez uma retrospectiva histórica, evidenciando que o dito "captador de recursos" para a área cultural. 
“...existe no mercado hoje, acho, aqui no Brasil, em São Paulo, são esses personagens chamados captadores que vieram preencher uma lacuna no mercado cultural, eu sou de uma época, eu pratico arte desde 1980, nos 80 não tinham leis de incentivo na cultura, eram pequenas chamas que aconteciam, eram projetos que iam e terminavam, acabavam, a primeira lei do fomento na cidade de São Paulo é de 2003, então eu passei a década de 80 e de 90. A primeira verba que eu lembro de ter ganhado ter forma significativa para montar algum espetáculo foi em 1996, que era a estreia dos teatros de bairro com uma peça chamada Flor da Obsessão, era uma verba pública, mas em forma de um pequeno edital. Então, desde esse momento aonde começa essa política em meados dos anos 90 nas leis, ela desagua hoje também nos captadores."

\section{2) Controle do trabalho do terceiro:}

2.1) Há um controle sobre quais empresas, potenciais patrocinadoras, cada um, destes terceiros, estão em contato, que é feito via planilha de Excel.

2.2) A formalização de que estas empresas terceiras podem representar a Pia Fraus é feita por e-mail.

\subsubsection{Fontes de Captação}

As fontes de captação de recurso que a produtora faz uso, atualmente, são:

- 50\% em leis de incentivo - especificamente lei estadual da Cultura (ProAC)

- 30\% de vendas de espetáculo para a rede SESC

- 10\% de parcerias com a Secretaria Municipal e Estadual de Cultura de São Paulo

- $10 \%$ de promoção de eventos, idas a festivais e vendas para escolas de oficinas e visitas ao espaço Pia Fraus.

O projeto já recebeu muitos fomentos, via editais.

O entrevistado traz uma visão histórica sobre a cultura:

“A minha primeira atividade no SESC foi em 1983, antes mesmo da Pria Fraus, mas o SESC dá um grande salto, e desenvolve seu entendimento do seu papel cultural ...... Quando começamos as prefeituras tinham um papel muito mais forte que hoje, elas "compravam" a cultura, prefeituras do interior de São Paulo, eu fazia Rio Claro, Ribeirão Preto, Jundiai, Limeira, com verbas municipais, não com verbas do estado. Então as prefeituras tinham um outro papel, elas perderam esse protagonismo, que foi um pouco para as mãos do SESC.” 
Resumidamente, poderíamos considerar o empreendimento Pia Fraus também como sociocultural, mas não somente sociocultural, devido a alguns projetos, que executa, ser direcionado para público pagante. Há em torno de 40 pessoas trabalhando diretamente em seus projetos. Estes projetos são socioculturais, quando disponibilizados gratuitamente e em regiões geográficas, onde o teatro não chegaria. Já impactaram, ao longo de sua trajetória, na casa dos milhões de pessoas. A receita, do último ano, foi de $\mathrm{R} \$ 900$ mil. Esta receita sustentou o empreendimento, no último ano, tendo uma contrapartida de despesas, que tornou justo o resultado, contando com:

- Fontes de captação: divididas entre 50\% em leis de incentivo - especificamente lei estadual da Cultura (ProAC), 30\% de vendas de espetáculo para a rede SESC, $10 \%$ de parcerias com a Secretaria Municipal e Estadual de Cultura de São Paulo, 10\% de promoção de eventos, idas a festivais e vendas para escolas de oficinas e visitas ao espaço Pia Fraus

- Estrutura de captação mista: esta estrutura não é dita, definida e nem nomeada claramente pelo entrevistado, mas para fins do trabalho, podemos considerar que a estrutura é mista por haverem pessoas internas, que cuidam dos editais e prestações de serviço, no contato com SESC's e demais. E por haverem 8 ou 9 empresas terceirizadas, que captam recursos, via leis de incentivo.

- Estratégias de captação: estas estratégias são classificadas, pelo entrevistado, com vínculo direto ao planejamento orçamentário da companhia. Apesar de não haver uma sistematização destas estratégias, elas são existentes e são divididas por tipo de fontes de captação a serem acionado, além da criação de projetos que possam fazer sentido ao público investidor - principalmente empresas. 


\subsection{Cia Vagalum Tum Tum}

"Shakespeare para crianças e jovens" (Frase extraída do site da companhia)

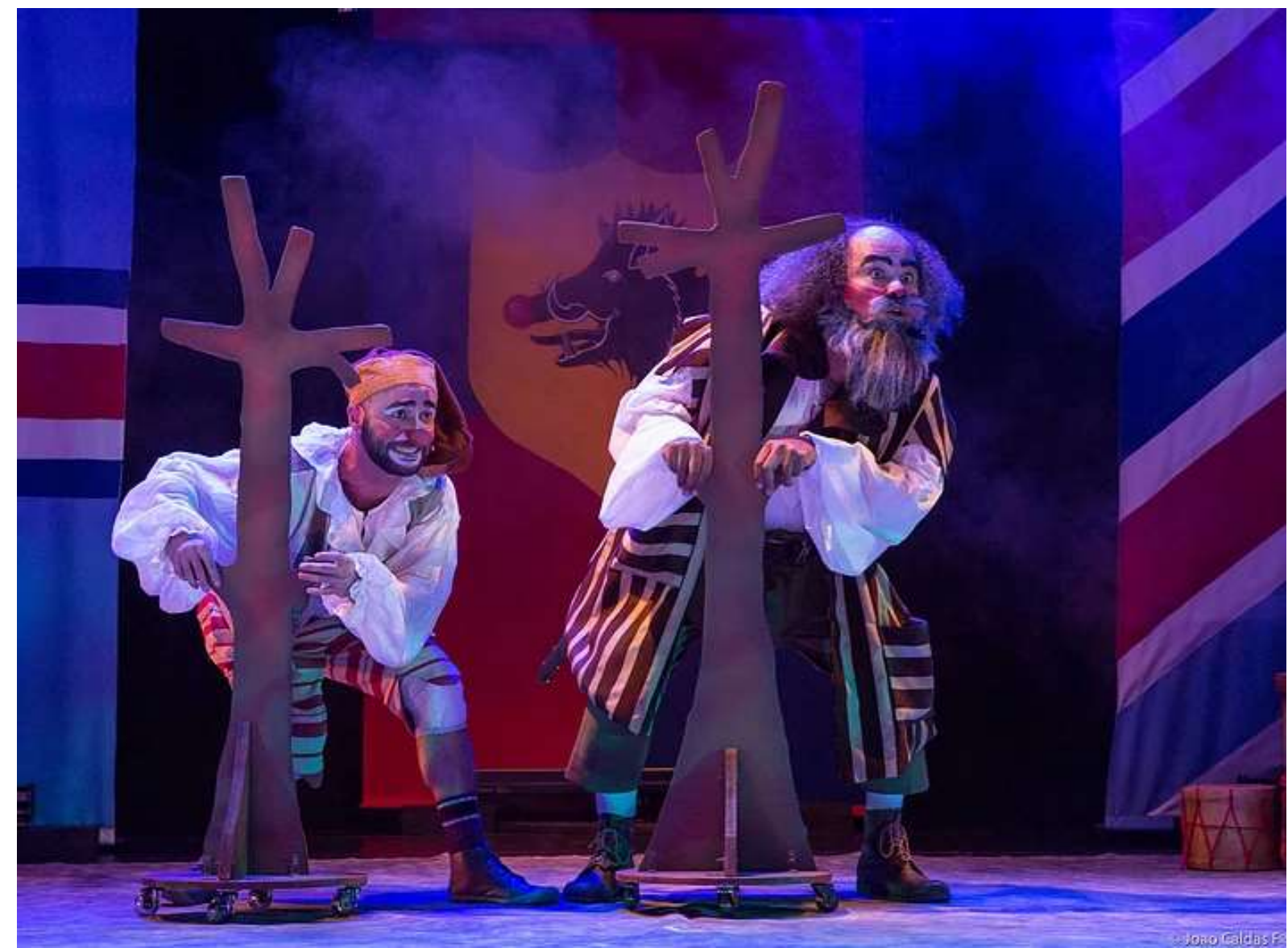

Figura 9 - Encenação de peça da companhia

(Fonte: site da Cia Vagalum Tum Tum)

\subsubsection{Características do empreendimento}

Quem são, histórico, tipo de natureza jurídica, faturamento, tempo de existência

A Cia. Vagalum Tum Tum tem natureza jurídica como empresa, foi fundada em 2001 por Ângelo Brandini e Christiane Galvan, com a proposta de pesquisar a fundo as técnicas do palhaço inseridas no cotidiano contemporâneo e o seu jogo com a criança. Nestes 17 anos de história desenvolveu um método, uma linguagem própria e original construída através da 
diversidade de conhecimento de cada profissional que trabalha na companhia, vindos do teatro, do circo, da área musical.

Shakespeare sempre foi uma paixão do núcleo artístico da Cia. e o desejo de contar suas histórias para o público infantil e jovem os levou a estudar e compreender sua obra ao máximo para que, com a ajuda do olhar transformador do palhaço, pudessem contar suas melhores tragédias e fazer rir e se emocionar, respeitando o ser em formação, mas nunca desrespeitando a sua inteligência. São todas histórias clássicas, montadas a mais de quatro séculos pelo mundo afora e são essenciais para a compreensão e formação do ser humano, segundo descritivo retirado do site da própria companhia.

Vale enfatizar que o trabalho de adaptação das peças de Shakespeare para crianças é inédito e único desta companhia, em todo o mundo, segundo entrevistado.

Tem uma receita bruta de $\mathrm{R} \$ 950$ mil, em média, nos últimos cinco anos, valor este que sustenta a Cia composta de 30 pessoas envolvidas nos trabalhos, mas não sustenta na plenitude os sócios proprietários, segundo entrevistado

\subsubsection{Projetos socioculturais}

Suas manifestações artísticas, número e o perfil das pessoas, prioritariamente atendidas, pelos projetos

Manifestação Artística: Teatro.

A encenação poderia ser uma definição melhor para a manifestação artística da Cia, pois como descrito acima, ela valoriza a música, a linguagem do circo e do palhaço para manifestarem-se cenicamente.

São cinco peças de teatro e sete diferentes oficinas, que compõem hoje o repertório de projetos, através dos quais a companhia se manifesta ao público.

As peças contam com textos adaptados por Angelo Brandini, premiado autor e diretor com vasta experiência na linguagem do palhaço, recurso utilizado para ajudar a contar histórias tão densas de forma leve e muito divertida. Os espetáculos são permeados por músicas originais e que são executadas ao vivo pelos atores no palco, trazendo um caráter lúdico ao enredo, entretendo e encantando a plateia.

Como público, a Cia tem prioritariamente crianças e jovens, mas os adultos - na medida que levam crianças - também são considerados. Este público atende aos critérios do sociocultural, quando a companhia faz espetáculos gratuitos e em locais geograficamente de difícil acesso ao teatro. 
Ao ser perguntado, na entrevista, se a Cia se considera uma organização sociocultural, a entrevistada coloca a questão geográfica para acesso ao teatro e a gratuidade como variáveis, seria passível de acréscimo a esta resposta que a Cia tem como missão levar cultura e alegria para as crianças, adultos, jovens com o fim de contribuir para a formação destas pessoas.

De todo modo, assim como a Pia Fraus, a Cia Vagalum também faz espetáculos pagos, o que não caracteriza, para fins desta pesquisa acadêmica, que suas atividades são, na totalidade de caráter sociocultural, apesar da Cia poder ser classificada como tal.

A Cia. Vagalum Tum Tum já impactou mais de 400 mil espectadores em todo o Brasil e no Chile, o último ano foi considerado com baixo impacto de público, sendo composto de 14 mil pessoas.

\subsubsection{Estratégias de Captação}

Apesar da entrevistada afirmar que não há muita estratégia, através das análises das respostas, percebe-se que não há um plano estruturado e estratégico, mas há várias estratégias sendo praticadas pela Cia, tais como:

- Contatar de forma recorrente as casas de espetáculos, através de e-mail marketing e telefone.

- Buscar de forma recorrente por editais e prêmios de fomenta afim de se inscreverem.

- Apresentarem-se em festivais como meio de potencializar a divulgação do projeto e consequente convite para apresentações.

Além disto, a Cia destaca a importância de se ter um material visual bem produzido para se conseguir "vender" teatro, ter presença atualizada nas redes sociais e site, bem como conseguir levar as pessoas para assistirem aos espetáculos.

\subsubsection{Estrutura de Captação}

Através das análises das respostas, percebe-se que, assim como outro empreendimento estudado nesta pesquisa, há uma vinculação direta dos serviços de captação à captação via leis de incentivo com pessoas jurídicas.

$\mathrm{Na}$ entrevista é respondido que há um terceirizado realizando o serviço de captação. Mas, vale salientar, para fins desta pesquisa, que a estrutura é mista. Pois, embora o entrevistado não tenha a percepção de que também exerce a função de captação, este a faz, na medida que contata, negocia e fecha as vendas para SESC's e se inscreve em Editais e Prêmios. Quanto à 
vendas para prefeituras, a Cia nomeou que é procurada para tal, logo não há um movimento, que parte do empreendimento, para esta fonte ser obtida. Abaixo, segue mais detalhes das estruturas:

- Interna: para procura de rede SESC e demais teatros ou casas de cultura.

- Terceirizada: com uma empresa exercendo a função, com foco em projetos aprovados em leis de incentivo.

Da terceirização, há dois pontos para destacar:

1) Motivo de Terceirizar

Este é um processo do qual a Cia afirma não ter pessoas e tempo suficientes para esta atividade. E adiciona que a captação é um processo bem específico, feito por um profissional que chega numa empresa, que conhece a linguagem daquela empresa, sabe como mostrar o trabalho, de forma que a empresa se interesse por ele, e complementa que talvez, se fosse para a própria Cia realizar não iria dar tão certo

2) Controle do trabalho do terceiro:

2.1) Há um controle sobre quais empresas, potenciais patrocinadoras, cada um, destes terceiros, estão em contato, que é feito via e-mail e telefone.

2.2) A formalização de que esta empresa terceira pode representar o projeto é feita por e-mail.

\subsubsection{Fontes de Captação}

Esta Cia tem suas fontes de recursos, atualmente, divididas da seguinte maneira:

- Vendas de espetáculos para SESC e SESIS: $60 \%$

- Vendas para prefeitura: $20 \%$

- Festivais de teatro: $10 \%$

- Outros: $10 \%$

A Cia cita outras fontes que tem como parceiras para a existência dos projetos, tais como Teatro Alpha, Cultura Inglesa, Prêmios como o Prêmio de Teatro Zé Renato da Prefeitura de São Paulo.

Um dado importante trazido pela Cia é que, apesar dos festivais não trazerem retorno financeiro para o sustento da Cia, pois o que se ganha nele se gasta na participação com viagem, hospedagem, entre outros. Os festivais são uma forma de propagar o teatro, pois eles são a 
"porta de entrada" das críticas, ali estão os críticos, os que irão levar a Cia para outros festivais e contribuir para a divulgação do trabalho desta.

No ano de 2018, a Cia atribui às Leis de Incentivo - federal e estadual - 30\% do que a organização arrecadará e a entrevistada afirma que a participação de leis não era tão expressiva, no passado. É colocada a questão de a organização ter trabalhado muito, feito "um nome" e ser reconhecido por isso, em São Paulo, principalmente, o que a ajudou a se manter sempre.

Resumidamente, poderíamos considerar o empreendimento Cia Vagalum Tum Tum também como sociocultural, mas não somente sociocultural, devido a alguns projetos, que executa, ser direcionado para público pagante. Há em torno de 30 pessoas trabalhando diretamente em seus projetos. Estes projetos são socioculturais, quando disponibilizados gratuitamente e em regiões geográficas, onde o teatro não chegaria. Já impactaram, ao longo de sua trajetória, mais de 400 mil pessoas, sendo 14 mil somente no último ano. A receita, do último ano, foi em torno de $\mathrm{R} \$ 950$ mil. Esta receita sustentou o empreendimento, no último ano, mas não aos sócios-proprietários, em sua plenitude, contando com:

- Fontes de captação: divididas entre $60 \%$ com vendas de espetáculos para SESC e SESIS, 20\% com vendas para prefeitura de São Paulo, 10\% com Festivais de teatro e os outros 10\%, com fontes variadas. Entrarão, em 2018, com 30\% das fontes sendo de recursos incentivados, por pessoas jurídicas.

- Estrutura de captação mista: esta estrutura não é dita, definida e nem nomeada claramente pelo entrevistado, mas para fins do trabalho, podemos considerar que a estrutura é mista por haverem pessoas internas, que cuidam dos editais e prestações de serviço, no contato com SESC's e demais. E por haver 1 empresa terceirizada, que captam recursos, via leis de incentivo.

- Estratégias de captação: Apesar da entrevistada afirmar que não há muita estratégia, através das análises das respostas, percebe-se que não há um plano estruturado e estratégico, mas há algumas estratégias sendo praticadas pela Cia, tais como contato recorrente com as casas de espetáculos, através de e-mail marketing e telefone; busca recorrente por editais e prêmios de fomenta afim de se inscreverem; apresentações em festivais como meio de potencializar a divulgação do projeto e consequente convite para apresentações. 


\subsection{Considerações Consolidadas}

Para tornar a pesquisa consistente, optou-se pela estratégia de estudo de caso múltiplo. Dado que são seis empreendimentos socioculturais analisados sob a perspectiva individual, a coleta e análise de dados realizadas de forma categorizada, permitiu, dentro das possibilidades de análises, traçar os resultados, bem como identificar semelhanças e diferenças entre a forma como estes empreendimentos captam seus recursos financeiros. Para tal, foi utilizada a categorização abaixo, já descrita e analisada individualmente ao longo deste trabalho:

- Características do empreendimento: quem são, histórico, tipo de natureza jurídica, faturamento, tempo de existência.

- Projetos socioculturais: suas manifestações artísticas, número e o perfil das pessoas, prioritariamente atendidas, pelos projetos

- Estratégias de Captação: devido à literatura e ao já exposto no referencial teórico optou-se por não haver subdivisões de estratégias de captação afim de deixar cada empreendimento estudado livre para expor o que faz sem influência do entrevistador ou do questionário de pesquisa.

- Estrutura de Captação: também como exposto no referencial teórico, esta categoria de análise será vinculada à estrutura ser terceirizada, interna ou mista.

- Fontes de Captação de Recursos: a presente pesquisa pode identificar as fontes de recurso, que cada empreendimento faz uso, através das respostas dadas ao questionário de pesquisa. Somente o Doutores da Alegria tinha também um gráfico ilustrativo destas participações em seu material institucional.

A partir destas cinco categorias de análises, obtivemos os resultados individuais e pudemos elaborar algumas considerações, levando-se em conta os seis empreendimentos estudados, que seguem:

Todos os empreendimentos que tem somente projetos socioculturais têm em sua missão as palavras "acesso", "transformar”, "social".

Todos os seis empreendimentos estudados e entrevistados fazem uso de leis de incentivo fiscais. Destes, quatro empreendimentos têm os incentivos fiscais, via pessoa jurídica, como o maior percentual de participação em suas fontes de recursos. Os dois empreendimentos que não são prioritariamente dependentes das leis de incentivo também são os mesmos dois empreendimentos que não possuem projetos socioculturais somente - Pia Fraus e Cia Vagalum Tum Tum. 
Todos os seis empreendimentos também já tiveram ou ainda têm iniciativas para obtenção de recursos, nas fontes produtos e/ou prestações de serviços.

Com exceção do ImageMagica, todos os empreendimentos já tiveram iniciativas inscritas e contempladas em prêmios ou editais de fomento à cultura.

A iniciativa que tem maior valor de receita é também a que tem maior diversificação de fontes de recursos - Doutores da Alegria.

As duas iniciativas - Doutores e ImageMagica - que tem maior valor de receita anual são também as que possuem estrutura de captação claramente definida, no momento que foram questionadas em suas entrevistas.

As demais iniciativas não percebem as suas funções internas, nas buscas por recursos, como uma atividade exercida para a captação de recursos. Poderíamos classificar esta percepção como realmente a ausência de uma estrutura organizada interna, mas, para fins deste trabalho, adotamos como referencial que se há uma pessoa, interna à organização, dedicada à captação de recursos, há uma estrutura interna para tal.

Todas as iniciativas têm estrutura de captação mista, contando com pessoas do time de trabalho e terceirizados para a obtenção de recursos.

Todos os seis empreendimentos relataram os terceiros como profissionais vinculados ao relacionamento com empresas e consequentemente com a obtenção de recursos via leis de incentivo.

Dois destes seis empreendimentos exaltaram a função e atividade de captação como algo que requer expertise - Cia Vagalum e BuZum - e que os captadores são os profissionais para fazerem isto.

Um dos empreendimentos - Doutores da Alegria - citou os terceirizados como consultores necessários para abrangência do projeto Doutores e um outro - ImageMagica - os citou como parceiros para a busca de recursos para projetos específicos.

Os outros dois empreendimentos - Pia Fraus e Ibirajá - colocam os captadores como necessários ao processo de obtenção de recursos.

Somente em um, dos seis empreendimentos, foi citado o uso de contrato formal para a contratação do serviço do captador de recursos - Doutores da Alegria. No ImageMagica, há o controle deste trabalho sendo exercido por um sistema chamado Asana. Nos demais empreendimentos esta relação se dá por email, telefone.

As estratégias são o tópico mais complexo de se encontrar padrões entre os seis empreendimentos socioculturais. Já havia um sinal de que isto poderia ocorrer ao examinarmos as referências teóricas deste trabalho, por isso optou-se por deixar livremente que cada 
entrevistado enumerasse ou dissesse abertamente sobre suas estratégias de captação, através das respostas às perguntas elaboradas e feitas para ele.

As duas organizações com maior valor de receita - Doutores e ImageMagica - também são os dois empreendimentos que tem maior clareza e planejamento de suas estratégias, com réguas de ações táticas e acompanhamentos periódicos destas.

Os demais empreendimentos chegam inclusive a citar ações estratégicas sem nomeá-las como tal ou ações táticas como sendo estratégia, conforme já dito em cada caso especificamente.

Há alguns elementos, que compõem uma estratégia, que são comuns a todos os empreendimentos: todos acreditam que o projeto deve ser visitado, visto ou vivenciado; todos destacaram o material visual ou apresentação visual bem elaboradas como ferramenta de trabalho

Metade dos empreendimentos enfatizaram a importância de se conseguir marcar uma reunião - ImageMagica, Doutores da Alegria, Ibirajá.

Todos os empreendimentos enfatizaram a importância de se manter relacionamento com as fontes de recursos para serem lembrados.

Os empreendimentos com maior receita são os mesmos que tiveram as entrevistas com tempo de duração mais curto, poderíamos até inferir algo no sentido de formação gerencial da equipe, além da formação artística, que podem contribuir nesta otimização de tempo ou a maior clareza de seu processo de captação.

As leis de incentivo aqui nomeadas - Lei Rouanet e ProAC principalmente - são a fonte de recurso prioritárias dos projetos socioculturais, aqui vale ressaltar que estas leis de incentivo têm como premissa o investimento na cultura somente e não em outra área social, o que pode explicar este percentual.

Estas leis também têm como premissa possibilitarem o acesso à cultura, em termos sociais e demográficos, apesar de já termos visto nos capítulos INTRODUÇÃO e REFERENCIAL TEÓRICO, que os grandes produtores de musicais e museus são os maiores recebedores deste incentivo. Aqui vale relembrar que o BuZum está entre os oitenta projetos que mais captaram recursos por estas leis, isto se deve ao fato de sempre terem tido um patrocinador com alto valor de incentivo para direcionar.

As leis também permitem que haja remuneração para a atividade de captação, o que talvez, possa levar os empreendimentos a associarem a atividade à única e exclusivamente uma forma de obtenção de recursos: o de incentivo fiscal em empresas. 


\section{CONCLUSÕES}

Ao optarmos por pesquisar um tema específico - captação de empreendimentos socioculturais -, dentro de uma área de estudo recente - empreendedorismo sociocultural - e ainda pouco explorada e estudada na literatura brasileira somados a uma pergunta de pesquisa de natureza qualitativa - iniciada com o "Como" - corria-se o grande risco de não haver padronização alguma dos resultados obtidos, tampouco que a pesquisa trouxesse resultados comparativos consistentes. Apesar do objetivo geral de pesquisa ser analisar como os empreendimentos socioculturais captam recursos, sob as óticas da estratégia, estrutura e fontes, havia uma expectativa da pesquisadora, adicional ao objetivo, por trazer nos resultados as linhas comparativas - com possíveis semelhanças e diferenças - entre as formas de captar recursos financeiros.

Para tornar a pesquisa consistente, optou-se pela estratégia de estudo de caso múltiplo, dado que são seis empreendimentos socioculturais analisados sob a perspectiva individual. Mas, para termos uma base de análise, passível de comparação, foi utilizada a categorização abaixo, já descrita e analisada individualmente ao longo deste trabalho:

- Características do empreendimento.

- Projetos socioculturais

- Estratégias de Captação

- Estrutura de Captação

- Fontes de Captação de Recursos

Ao analisarmos cada empreendimento individualmente, em cada uma destas categorias, bem como traçar as considerações consolidadas, não poderíamos deixar de remontar ao início deste trabalho, onde falávamos do desafio de sustentabilidade dos empreendimentos socioculturais, num cenário brasileiro que remonta ao investimento social privado como Responsabilidade Social associando e analisando as escolhas de investimento na cultura no mesmo escopo que outras muitas áreas sociais tão importantes quanto a cultura. Num cenário brasileiro, onde as iniciativas públicas iniciaram, de forma estruturada, também numa perspectiva histórica recente, datando por exemplo, de 1985 a formação do Ministério da Cultura Brasileira.

Entre outros muitos fatores que poderíamos relembrar, neste momento, o fato é que os seis empreendimentos estudados conseguem exercer suas manifestações artísticas captando recursos financeiros, no Brasil. Embora quatro deles - Pia Fraus, ImageMagica, Cia Vagalum 
e Ibirajá tenham respondido que se sustentam com restrições, todos eles responderam que exercem suas missões de forma sustentável.

Isto traz, em si, uma perspectiva positiva quanto ao investimento na área sociocultural brasileira, mas é importante lembrar que o estudo foi pautado em empreendimentos socioculturais que exercem suas atividades, há mais de cinco anos e que também estão presentes no estado de São Paulo - maior estado produtor e "consumidor" da cultura brasileira. Neste sentido, a produção e o consumo de cultura do local ao qual o empreendimento está podem influenciar diretamente para a produção e consumo do sociocultural também.

Há algumas conclusões que podemos retirar da pesquisa e que poderiam vir a servir a outros empreendimentos socioculturais, independente da manifestação artística que se utilizam e do local ao qual estão estabelecidos, são as conclusões baseadas nas variáveis controláveis e internas ao empreendimento por si só, tais como:

- Há inúmeras fontes de captação disponíveis para acesso, como as listadas ao longo deste trabalho. Mas, as que são fontes comuns e utilizadas por todos os empreendimentos deste estudo são os editais, prêmios de fomento, leis de incentivo, prestações de serviço para escolas e centros culturais.

- Os empreendimentos, que têm maior valor monetário em termos de receita, são também os que têm um planejamento orçamentário, estrutura, estratégia e diretrizes de atuação do empreendimento como sua missão e causas muito bem definidas.

- A estrutura mista é a mais utilizada pelos empreendimentos socioculturais, mesmo que não seja totalmente definida e clara em suas funções. Um fato curioso é perceber que os dois empreendimentos, que captam maior valor monetário, iniciaram suas atividades com a estrutura pouco definida, exerciam a atividade de captação de forma orgânica e ao longo dos anos, é que desenharam e botaram em prática uma estrutura definida com estratégias a serem cumpridas.

- As estratégias são a parte mais difícil de se concluir resumidamente, mas podemos extrair que há muitas ações táticas passíveis de serem feitas que não necessariamente foram pensadas de forma organizada e estratégica. Mas, há alguns pontos em comum, a todos os empreendimentos, que podem ser aproveitados por outros: um material visual bonito, redes sociais atualizadas, um projeto consistente com uma causa e uma ferramenta artística bem elaborada e executada, reuniões marcadas com seus potenciais investidores, busca constante por editais e prêmios de fomento. Aqui faz-se necessário enfatizar a importância de se terem pessoas com olhar gerencial apurado para aplicarem conhecimentos de gestão ao empreendimento sociocultural. 


\section{REFERÊNCIAS BIBLIOGRÁFICAS}

AMORIM, R. O.; BATISTA, L. E. Empreendedorismo feminino: razão do empreendimento. Revista Núcleo de Pesquisa da Finan, São Paulo, v.3, n. 3, 2012.

ARGAN, Giulio Carlo. História da Arte Italiana: de Giotto a Leonardo. São Paulo: Cosac \& Naif, 2003.

ASHOKA; McKinsey\&Company. Empreendimentos Sociais Sustentáveis: Como elaborar planos de negócios para organizações sociais. São Paulo: Peirópolis, 2001.

. Negócios sociais sustentáveis. São Paulo: Peirópolis, 2006.

BARDIN, L. Análise de conteúdo. Lisboa: Edições 70, 1977.

BARROS, A.J.S; LEHFELD, N.A.S. Fundamentos de Metodologia: Um guia para iniciação científica. São Paulo: Makron, 2000.

. Mercado Cultural. São Paulo: Instituto Pensarte, 2001.

BRANT, Leonardo. Diversidade Cultural. São Paulo: Instituto Pensarte, 2005.

BORNSTEIN, David. Como mudar o mundo: empreendedorismo social e o poder das novas idéias. Record, 2005.

BAUER, M. W.; GASKELL, G. Pesquisa qualitativa com texto, imagem e som: um manual prático. 3. ed. Petrópolis, RJ: Vozes, 2002.

CAMARA, A. F. N. Conta de juros \& favela. Com2B: Rio de Janeiro, 2013.

CARASSO, Jean- Gabriel. Revista Sala Preta da USP. Volume 1. Seção: EM PAUTA. Artigo 2. Edição $n^{\circ}$ 12, 2012.

CSIKSZENTMIHALYI, M. Creativity: Flow and the psychology of discovery and invention. New York: Harper Collins, 1996.

COSTA, Ivan Freitas da. Marketing Cultural: O patrocínio de atividades culturais como ferramenta de construção de marca. São Paulo: Atlas, 2004.

CRUZ, Célia Meirelles; ESTRAVIZ, Marcelo. Captação de diferentes recursos para organizações sem fins lucrativos. São Paulo: Global, 2000.

DRUCKER, Peter. Innovation and Entrepreneurship: Pratice and Principles. Londres: Heinemann, 1985.

DUARTE, Rodrigo. Indústria Cultural. Rio de Janeiro: FGV, 2010.

FISCHER, Rosa Maria. Empreendedorismo Social e Desenvolvimento Sustentável. In: Os desafios da formação em gestão social. Tocantins: Coleção ENAPEGS, volume 2, 2008. 
- Novas dimensões da Responsabilidade Social: A Responsabilidade pelo Desenvolvimento. In: Responsabilidade Social e Governança de Cláudio Pinheiro Machado Filho, São Paulo: Thomson, 2006.

. Políticas Sociais - Ideias e Práticas. Empreendedorismo social: apontamentos para um debate, pp. 183-206. São Paulo: Moderna, 2011

Agenda social no Brasil. In: MENDONÇA, P. E. (Org.). Gestão Social Mobilizações e conexões. São Paulo: LCTE Editora, 2012.

FISCHMANN, A.A. e ALMEIDA, M.I.R. Planejamento estratégico na prática. $2^{\mathrm{a}}$ ed., $3^{\mathrm{a}}$ Tiragem. São Paulo: Atlas, 1995.

GIL, A.C. Como elaborar projetos de pesquisa. São Paulo: Atlas, 2002.

GOMES, A. F. SANTANA, W. G. P.; ARÁUJO, U. P. Empreendedorismo Feminino: o estado da arte. XXXIII Encontro da ANPAD. São Paulo, 19 a 23 set, 2009.

HOWKINS, J. The creative economy: how people make money from ideas. Penguin, 2011.

KRAKAUER, P.; MARQUES, J. A.; ALMEIDA, M. I. R. Mestrado Profissional em Administração Profissional em Administração: Diretrizes na Elaboração dos Projetos. In: XXXIX ENANPAD, Belo Horizonte, 2015.

LIMONGI-FRANÇA, Ana Cristina. Comportamento Organizacional: Conceitos e Práticas. São Paulo: Ed. Saraiva, 2005.

MALHORTA, N.K. Pesquisa de Marketing: foco na decisão. 3. ed. São Paulo: Pearson Hall, 2011.

MINTZBERG, Henry; AHLSTRAND, B.; LAMPEL, J. Safári de estratégia: Um roteiro pela selva do planejamento estratégico. 2.ed., Porto Alegre: Artmed, 2010.

OLIVEIRA, P. G.; SOUZA NETO, B. Empreendedorismo e Gestão Feminina: Uma análise do Estilo Gerencial de Mulheres Empreendedoras no Município de São João Del-Rei, Minas Gerais. VI Encontro de Estudos Organizacionais da ANPAD. Florianópolis, SC, 23 a 25 maio, 2010 .

PEREIRA, Custódio. Captação de Recursos. São Paulo: Mackenzie, 2001.

PARIZZI. Manual Técnico sobre as leis de Incentivo à Cultura. Cuiaba: Carlini e Caniato, 2011.

REIS, Ana Clara Fonseca. Marketing Cultural e Financiamento da Cultura. São Paulo: Thomson, 2006.

SANDBERG, Sheryl. Faça acontecer. São Paulo: Companhia das Letras, 2013. 
YIN, Robert K. Estudo de caso: planejamento e métodos / Robert K. Yin; trad. Daniel Grassi - 2.ed. -Porto Alegre: Bookman, 2003.

YUNUS, Muhammad. O banqueiro dos pobres. São Paulo: Ática, 2000.

\section{SITES CONSULTADOS:}

- Unesco

- $\quad$ ONU (Organização Nações Unidas)

- $\quad$ Ministério da Cultura (MINC)

- $\quad$ SEBRAE

- $\quad$ Secretaria do Estado da Cultura de São Paulo

- $\quad$ ICE

FONTES DE DADOS CONSULTADOS:

- SEBRAE

- CENSO

- IBGE

\section{SITES DAS INSTITUIÇÕES:}

Produtora Cultural BuZum: http://buzum.com.br/

Produtora Cultural ImageMagica: http://imagemagica.org

Associação Doutores da Alegria: https://www.doutoresdaalegria.org.br/

Ibirajá Produtora Cultural: http://www.ibirajaproducoes.com.br/

Pia Fraus Produtora Teatral: http://piafraus.com.br/site/

Cia Vagalum Tum Tum de Teatro Infantil: https:/www.ciavagalum.com.br/ 


\section{APÊNDICES}

APÊNDICE 1 - Modelo de Protocolo para Estudo de Caso

APÊNDICE 2 - Questionário da Entrevista (antes do pré-teste)

APÊNDICE 3 - Questionário Final da Entrevista (versão aplicada)

APÊNDICE 4 - Transcrição das Entrevista BuZum

APÊNDICE 5 - Transcrição das Entrevista ImageMagica

APÊNDICE 6 - Transcrição das Entrevista Doutores da Alegria

APÊNDICE 7 - Transcrição das Entrevista Ibirajá Produtora Cultural

APÊNDICE 8 - Transcrição das Entrevista Cia Vagalum Tum Tum

APÊNDICE 9 - Transcrição das Entrevista Pia Fraus Produtora Teatral 


\section{APÊNDICE 1 - Modelo de Protocolo para Estudo de Caso}

\section{Etapa 1}

Universo: Empreendimento SocioCulturais

Checar características: quem são, histórico, tipo de natureza jurídica, faturamento, tempo de existência.

Checar fotos no site: tem ou não?

Checar apresentações: tem ou não?

Realizar visita ao projeto e ao empreendimento: checar público, conversar com público, verificar os projetos sendo executados.

\section{Etapa 2}

Escolher os empreendimentos: eles devem cumprir premissa sociocultural

Escolher os entrevistados: devem estar envolvidos diretamente com captação

\section{Etapa 3}

Fazer convite para entrevista

Receber aceite

\section{Etapa 4}

Elaboração das perguntas para entrevista em categorias:

- Características do empreendimento

- Projetos socioculturais

- Estratégias de Captação

- Estrutura de Captação

- Fontes de Captação de Recursos

\section{Etapa 5}

Realizar entrevistas verificando se as categorias obtiveram informações cedidas na entrevista.

\section{Etapa 6}

Juntada dos dados primários em categorias. 


\section{APÊNDICE 2 - Questionário da Entrevista (antes do pré-teste) Apresentação ao entrevistado}

Os objetivos desta entrevista são:

(a) identificar você e a organização que você representa no ecossistema brasileiro de empreendimentos socioculturais.

(b) entender seu processo de captação de recursos: estrutura interna, estratégias de captação e fontes destas captações.

A duração prevista para esta entrevista é de aproximadamente 60 minutos. Com o objetivo de garantir maior confiabilidade na análise das respostas, a entrevista será gravada. Podemos começar?

1) Qual o nome da sua instituição e qual a sua atividade nela?

2) Há quanto tempo ela existe?

3) Qual a missão da instituição?

4) Os projetos refletem a causa da instituição?

5) Qual a estrutura atual para dedicação à captação de recursos pela sua instituição?

6) Esta estrutura sempre foi a mesma, ao longo dos anos? Caso não: como era?

7) Caso não haja estrutura, quem faz a captação de recursos para a instituição? Há algum responsável ou a captação é terceirizada?

8) Caso seja terceirizada, como vocês escolhem a empresa terceirizada?

9) Caso haja mais de uma empresa, como vocês controlam a captação?

10) São quantos?

11) Porque vocês escolheram terceirizar?

12) Para a captação de recursos: vocês fazem estratégias para tal? Se sim, quais são elas?

13) Se há estratégia, de quanto em quanto tempo ela é elaborada? Vocês sempre a seguem ou há mudanças?

14) Vocês identificam quais são as potenciais fontes de recursos? Se sim, como o fazem? E como as aciona?

15) Quando vocês buscam a captação de recursos, como vocês se apresentam ao investidor? 
16) Quando vocês terceirizam a captação de recursos, como vocês se apresentam ao intermediário?

17) Vocês ou o terceiro falam da causa da instituição?

18) Vocês buscam investimento para a instituição ou para os projetos da instituição?

19) Quando vocês conseguem recursos, vocês mantêm relacionamento com a instituição? Por quanto tempo e de que forma?

20) Os investimentos /empresas são renováveis? Se não, qual a razão, segundo sua percepção?

21) Vocês têm quantos projetos por ano?

22) Todos estes projetos existem independente das leis de incentivo ou somente via leis de incentivo?

23) Se são via leis de incentivo somente, são quais as leis?

24) Quais são as fontes de captação destes projetos? Pessoas físicas, jurídicas, editais públicos (estaduais, municipais ou federais), leis de incentivo (estaduais, municipais ou federais), parcerias de outra natureza, eventos, prestações de serviço ou o quê?

25) Você poderia me dizer em percentual de participação de cada fonte?

26) Sempre foi assim ou se modificou ao longo dos anos da instituição? Se se modificou, qual a razão segundo sua percepção?

27) Você acredita que você sobreviveria sem leis de incentivo? 


\section{APÊNDICE 3 - Questionário Final da Entrevista (versão aplicada) Apresentação ao entrevistado}

Os objetivos desta entrevista são:

(a) identificar você e a organização que você representa no ecossistema brasileiro de empreendimentos socioculturais.

(b) entender seu processo de captação de recursos: estrutura interna, estratégias de captação e fontes destas captações.

A duração prevista para esta entrevista é de aproximadamente 60 minutos. Com o objetivo de garantir maior confiabilidade na análise das respostas, a entrevista será gravada. Podemos começar?

1) Qual o nome da sua instituição e qual a sua atividade nela?

2) Há quanto tempo ela existe? E você a considera uma instituição sociocultural?

3) Quantos projetos socioculturais estão ligados à esta instituição? Há quanto tempo eles existem?

4) Qual a missão da instituição?

5) Os projetos refletem a causa da instituição?

6) Qual a estrutura atual para dedicação à captação de recursos - nomear o que é - pela sua instituição ou vocês terceirizam?

7) Esta estrutura sempre foi a mesma, ao longo dos anos? Caso não: como era?

8) Caso não haja estrutura, quem faz a captação de recursos para a instituição? Há algum responsável ou a captação é terceirizada?

9) Caso seja terceirizada, como vocês escolhem a empresa terceirizada?

10) Caso haja mais de uma empresa, como vocês controlam a captação?

11) São quantos?

12) Porque vocês escolheram terceirizar?

13) Para a captação de recursos: vocês fazem estratégias para tal? Se sim, quais são elas?

14) Se há estratégia, de quanto em quanto tempo ela é elaborada? Vocês sempre a seguem ou há mudanças?

15) Vocês analisam a estratégia do terceiro, caso o serviço seja terceirizado? 
16) Vocês identificam quais são as potenciais fontes de recursos? Se sim, como o fazem? E como as aciona?

17) Quando vocês buscam a captação de recursos, como vocês se apresentam ao investidor?

18) Quando vocês terceirizam a captação de recursos, como vocês se apresentam ao intermediário?

19) Vocês ou o terceiro falam da causa da instituição?

20) Vocês buscam investimento para a instituição ou para os projetos da instituição?

21) Quando vocês conseguem recursos, vocês mantêm relacionamento com o terceirizado? Por quanto tempo e de que forma?

22) Quando vocês conseguem recursos, vocês ou o terceiro mantém relacionamento com a instituição? Por quanto tempo e de que forma?

23) Os investimentos /empresas são renováveis? Se não, qual a razão, segundo sua percepção?

24) Vocês têm quantos projetos por ano?

25) Todos estes projetos existem independente das leis de incentivo ou somente via leis de incentivo?

26) Se são via leis de incentivo somente, são quais as leis?

27) Quais são as fontes de captação destes projetos? Pessoas físicas, jurídicas, editais públicos (estaduais, municipais ou federais), leis de incentivo (estaduais, municipais ou federais), parcerias de outra natureza, eventos, prestações de serviço ou o quê?

28) Você poderia me dizer em percentual de participação de cada fonte?

29) Sempre foi assim ou se modificou ao longo dos anos da instituição? Se se modificou, qual a razão segundo sua percepção?

30) Você acredita que você sobreviveria sem leis de incentivo?

31) Há uma concorrência alta para o uso destes recursos, na sua percepção? Se sim, com quem vocês concorrem? 


\section{APÊNDICE 4}

\section{Entrevista Buzum}

Eu sou sócia do Buzum, que chamamos projejo Buzum, companhia Buzum, eu sou sócia e tenho outros dois sócios dentro do projeto, o Bento Andretta, que criou o projeto, que teve a ideia e junto comigo faz toda a parte criativa, de aprovação de artes, construção do roteiro dos espetáculos, toda a parte artística do projeto, o Jackson Willis, que cuida da parte administrativa e financeira; e eu também da gestão do projeto, equipe, atores e as possibilidades de novos patrocínios, novos parceiros, e, enfim, todo o guarda-chuva que envolve a gestão do projeto sou eu quem faço.

O Buzum existe de 2010, a gente estreou em setembro de 2010, então agora em setembro de 2018 iremos fazer 8 anos.

Acho que a principal do Buzum é levar o teatro ao encontro do público, principalmente onde há público, onde há pessoas que não tenha acesso facilitado ou nenhum acesso as artes cênicas. A ideia de colocar roda no teatro e levar o teatro ao público é o que move o projeto, existem várias outras ações que o projeto envolve, desde projetos educativos com o livro do professor até algumas coisas que mencionarei no decorrer da entrevista, mas a principal é poder levar o teatro ao encontro do público sem que o público pague para receber, então a ideia é que esse projeto já vá incentivado de alguma maneira.

$\mathrm{Na}$ verdade, temos empresas captadores parceiras, a gente não vende, quando falamos em leis de incentivo, quando a gente vende, e ainda assim é muito tímido dentro do projeto, é oferecer para escolas particulares, ou para SESC's SESI's, outras maneiras de viabilização que não representam nem 5\% do movimento do projeto, o substancial do projeto, que funciona ao encontro do principal missão dele é projeto financiado, então, Leis Rouanet, Proac e até editais. A Lei Rouanet é o maior movimento, Proac também, então temos empresas parceiras, não há ninguém aqui de dentro, temos alguns captadores que trabalham com a gente que oferecem o Buzum para o seu rol de empresas, e aí a gente paga o valor estipulado por lei que é $10 \%$ da captação.

Ela é terceirizada, a gente busca parceiros e os parceiros nos buscam também, percebo isso de uma maneira muito orgânica com os parceiros que tem o mesmo ideal que o nosso, então normalmente as empresas que trabalham com a gente elas apresentam projetos muito próximos aos nossos, dificilmente uma empresa vai apresentar um grande musical ou um projeto muito comercial e a gente, isso até pode acontecer, mas eu vejo que maioria dos empresas que 
trabalham com a gente, tanto as captadoras, até as empresas que elas apresentam são empresas que tem o foco em projetos sociais e culturais, e até muito desses itinerantes.

É, a gente escolhe as empresas que vamos trabalhar, mas as empresas também escolhem a gente. Eu acho que realmente é muito orgânica essa comunicação, ou eu procuro empresas que se encaixem com a gente, ou as empresas que já estão procurando algo do gênero entram em contato conosco. Como o Buzum é um projeto muito amplo para a captação, porque ele é itinerante, ele é social, ele tem cotas acessíveis, é um projeto que eu posso ter um patrocínio pequeno e executá-lo, pois as vezes há esse problema, alguns projetos precisam de um patrocínio muito grande, como a gente é dia, com cotas que podem ser de até um ou dois dias...então temos esses dois caminhos, eu ir atrás da empresa e as empresas virem atrás da gente. E a gente teve muita sorte, ou muita coerência, de só trabalhar com empresas muito sérias, acho que nunca tive contato com alguma empresa de captação picareta, posso até ter tido, mas obviamente o negócio não caminhou.

Eu tenho uma relação de contato com essas captadoras, tenho uma planilha de Excel, então o captador me manda perguntando se pode apresentar para tais e tais empresas, e eu vou colocando essas empresas dentro dessa planilha. O primeiro que me mandar, o segundo que me pedir a mesma empresa, eu digo que não podemos, pois já temos o primeiro ali, é um pouco por ordem de chegada, digamos assim, o que as vezes foge um pouco do meu controle são captadores que na angústia do dia a dia, porque precisa mandar logo, não me manda, apresenta para uma empresa, me manda depois, e aí dá match com outro, e então preciso estabelecer uma conversa para sabermos quem recua quem não recua. Mas, geralmente, as coisas são muito fluídas, as empresas me mandam posso apresentar para tais e tais, eu checo com minha lista para saber se já foi apresentado e digo que sim ou se já foi, digo que não.

Eu tenho umas sete empresas mais ou menos.

Por vários motivos, um porque não temos esse norral, acho que é um trabalho muito sério, não é qualquer um que pode fazer, acredito que você tenha que ter esse norral, acho até que poderíamos ter, mas o projeto tem tantas possibilidades, que prefiro focar a nossa energia em potencializar o Buzum do que potencializar possíveis rendas, a gente não é vendedor, a gente não tem um hol de empresas captadores, eu teria que ligar atrás de cada empresa, então já que existe esse serviço, porque não? E a captação especificamente é um valor que está lá aprovado por lei, então, não me diz respeito ter esse valor para a gente, eu não acha que faça muito sentido, eu prefiro ter empresas parceiros que acho que irá potencializar muito mais a venda, essas tem contatos com muitas outras empresas, eu acho que a gente tem um projeto muito legal, acho que tem espaço para todo mundo, então eu não penso algo como, a outra empresa também 
apresenta um teatro itinerante, acho que tem espaço para todo mundo trabalhar, então acho que também para fomentar esse mercado cultural, é importante gerar contatos, é isso.

A estratégia é muito do terceiro, mas o que fazemos é estar com parceiros que tenham muita sinergia com a gente. Temos alguns parceiros que apresentam o Buzum para empresas que a gente quer que apresente, por exemplo, eu tenho um parceiro que é um parceiro ativo, como eles chamam, então eu faço uma lista com várias empresas que eu gostaria que patrocinassem o Buzum, por vários motivos, por que eu gosto da empresa, porque acho que é uma empresa com grande poder de patrocínio, porque está numa região em que eu gostaria de ir, então eu mando as ideias, esse parceiro concorda e vai atrás dessas. Eu acho que a grande estratégia do Buzum é ter um projeto muito sólido, a gente tem um material de divulgação muito legal, principalmente o material, o material do próprio projeto, o livro do professor, o gibi, o material que a gente entrega para as crianças e os professores, e que está dentro da lei Rouanet, é um material muito rico, pois a gente quis fazer um material bem bacana para que o professor quisesse mesmo ter, a criança quisesse ter, para que a logomarca do patrocinador tivesse inserida num material bacana e que esse próprio material se vendesse, mostrando o quão sério é o projeto, então acho que fazer o projeto muito aliado ao objetivo dele, à missão dele, é nossa maior estratégia de venda porque a gente consegue que o projeto assim seja de fato de verdade, então quando a missão de uma empresa é patrocinar projetos itinerantes, há a sinergia.

Eu deixo para o terceirizado.

Apresento normalmente ligando, explicando o que é o Buzum, como funciona o projeto, envio o e-mail com a apresentação do Buzum, um power point simples: o Buzum é um ônibus transformado em teatro que vai ao encontro do público, a gente já existe há 7 anos já atendeu mais de meio milhão de crianças, assim o projeto por si só vai se vendar, vai mostrar o que é. Não, foi tudo acontecendo de forma muito orgânica, muito natural também. Como a gente teve muita sorte de ter um patrocínio no primeiro ano do projeto, da Jota Leiva, que é uma grande captadora, e a gente já tinha o contato com eles, eles já nos conheciam, a gente não teve que ir atrás, a gente teve o primeiro projeto e no começo algumas captadoras vieram atrás da gente, e aí eu fui percebendo que não podia me acomodar nesse lugar e fui buscando. No ano passado fiz uma grande busca, mandei e-mails, fui atrás de outros captadores, convidei gente para vir aqui, mas não posso te dizer que tive uma regularidade. Agora, por exemplo, é época de Proac então é um momento que vou fazendo uma manutenção, vou conversando com esses parceiros. Lá para o segundo semestre começo a falar em Rouanet, então depende da época.

Para os projetos do Buzum, porque os nossos investimentos eles são muito específicos no Pronac por Proac, então os projetos são específicos, as vezes de circulações e espetáculos 
específicos, ou projetos que eu previ circulação de alguns espetáculos, porque tem empresas que querem o Buzum, não interessa qual o espetáculos eles querem levar o teatro na periferia, tem empresa que quer levar teatro na periferia com um espetáculo sobre água, então eu me programo segundo a demanda e segundo o material que eu tenho, porque não dá para fazer mágica e ter um projeto aprovado de hoje para amanhã.

Primeiro é o Buzum, o que é o Buzum, acho que esse é o grande lance, o fato de ser um ônibus que leva teatro, que vai ao encontro do público, a menos que ele já saiba que a empresa quer um espetáculo sobre água, então ele apresenta o Buzum mas com a especificidade do projeto 13 Gotas, por exemplo. Mas, a grande maioria dos captadores nas reuniões, e em grande parte delas eu estou presente também, pois eles me pedem para ir junto apresentar, $90 \%$ da reunião está focada no que é o projeto, mas já estive em uma reunião em que queriam falar sobre lixo, eu por sorte tinha o espetáculo de lixo no Proac, mas se eu não tivesse, teria de dizer, olha, esse é o projeto Buzum, se quiserem apresentar algo no ano que vem, ou, temos esse projeto aqui sobre a água, que é tão legal quanto, sei que você quer falar de lixo, mas enfim, até mesmo também para a empresa entender que as vezes não necessariamente falar de um assunto específico é sucesso. Tanto que a CCR nossa maior patrocinadora de Rouanet nunca pensou em tema, eles nunca falaram de tema, e estão conosco há 7 anos. Então vai muito do nosso feeling com a empresa e do que temos na manga, também.

Com a CCR, te darei um exemplo prático, a gente mantinha a relação com o captador e nesse caso específico, o captador era mais que um captador, porque ele era um contratado da empresa também, ele era um consultor da CCR. Então eu falava diretamente com o captador, e muito pouco com a CCR, com a empresa eu falava coisas pontuais, e o captador era que ia passando tudo para mim. Eu nesse caso eu falo por toda a execução do projeto, no antes, no durante e se precisar no depois. Eu normalmente falo com as empresas de captação durante o processo de captação, antes, durante e na entrega. Mas isso depende muito de empresa para empresa, de captador para captador, tem captador que capto, entrou e já fala pode falar direito com a empresa, me colocam em cópia e sou eu quem define as datas, os locais, tudo diretamente com a empresa. Mas, quando falo com a empresa final é bem no durante a execução do projeto e depois para mandar o relatório, quando eu falo com o captador aí já é sempre antes, durante e depois. Tem alguns captadores que converso ao longo de todo o ano, então depende um pouco de empresa para empresa.

Os que são renováveis, eu tenho um investimento que é inclusive o investimento base do projeto, que é renovável, e eu acho que ele é renovável porque houve uma sinergia entre projeto e empresa, a missão da empresa é nossa missão também. Mas, acho que no futuro pode não ser 
renovável também por uma questão de mudança interna das políticas da empresa, então acho que é por isso que os que não são renováveis não se renovam. A gente, no geral, tem sempre um retorno muito positivo das empresas, mas quando essa empresa não renova acho que é ou porque como são projetos incentivados a gente depende da venda, depende de lucro, ainda que Proac, porque precisa produzir para pagar o imposto, ou é porque estamos em um momento de crise no país e diminui o investimento da empresa, e então ela tem outro projeto que tem mais a ver que o nosso, e aí ela prefere o outro, ou porque ela quer mudar o pensamento mesmo. Acho que tem dois pensamentos de empresas, vamos ficar neste que dá certo e eu gosto, ou vamos variar porque temos que variar o incentivo público. Mas, até hoje nunca tive uma devolutiva no sentido de o projeto não ser legal, toda a devolutivo que temos é positiva, mas talvez no próximo ano eles tenham querido variar.

Nesse ano tempos um Pronac, um projeto de Rouanet, que é o que faremos. E dentro desse Pronac tem alguns espetáculos, então eu posso circular com alguns e montar outros, e temos três Proac's que são aptos para ser captados, e estamos esperando abrir o Proac, então isso é ao longo do ano. No ano passado, por exemplo, tivemos dois Pronac, projeto da lei Rouanet, e um projeto de Proac que foi captado, e a gente ganhou um fomento, que é um edital, que vale ainda para esse ano. Então varia de ano para ano.

Esses projetos apenas via lei de incentivo. Ano passado tivemos 3 projetos de leis de incentivo e 1 edital, este ano temos 1 projeto de lei de incentivo, e 1 edital e possibilidades, como captar Proac, escrever-nos em editais.

Lei Rouanet e ProAc ICMS.

90\% lei Rouanet, pessoa jurídica, não temos nenhuma lei Rouanet pessoa física. 8\% Proac, temos pessoa física do Buzum, pessoa física da CRB que é uma empresa, um CNPJ parceiro, quando falo CNPJ parceiro é porque é uma empresa que é do Beto, do Jackson, e minha, que a gente também usa para colocar os projetos, o CNPJ que a gente usa para fazer Proac, pois é uma empresa que o Beto já tinha do circo e os outros sócios saíram, e ficou com ele, então essa é mais uma pessoa jurídica. E ainda tem mais algumas pessoas físicas parceiras, eu tenho pessoa física, temos a Fabiola que trabalha aqui com a gente e tem cadastro de pessoa física. Então Proac é como a gente vai conseguindo, parceiros ou a gente mesmo. E tem os editais públicos, que é uma porcentagem bem pequena, de quando a gente consegue ganhar, sempre com o nome do Buzum, e venda é quase nada.

No Buzum sempre foi assim, o Buzum nasceu assim, mas na Pria Fraus, que é a companhia de onde vem o Buzum, que é uma companhia que fará 35 anos, pelo que entendo foi mudando ao longo dos anos. Até porque não tinha a Rouanet, Proac tão pouco, então era muita venda, muita 
venda para SESC, muita venda para escolas, para festivais. Não que a Pia Fraus não funcione mais nesse sentido, continua muito na venda, mas o Buzum foi mudando um pouco o pensamento e as maneiras de se viabilizar projetos sociais principalmente.

Eu acho que hoje, pela visão do Buzum que tenho para dar, sem as leis de incentivo acho que não teríamos grande parte dos projetos sócios culturais que acontecem.

Eu tenho minha percepção dentro da bolha que eu vivo, eu não tenho esses números, essa estatística real, eu acho que o volume de dinheiro dos maiores proponentes que mais recebem dinheiro, os 20 maiores são de marketing, grandes musicais, grandes temporadas, porém estamos na lista, estamos entre os 80 ou 90 proponentes que mais captaram ao longo desses anos, então somos um projeto que tem montante captado significativo ao longo desses 8 anos e que atendeu uma quantidade muito grande. Eu não conheço outro projeto como o nosso, com o mesmo montante, então por isso falo da bolha em que vivo, eu acho que a maioria é de não é de projetos sociais, mas acho que isso tem mudado ao longo dos anos. Eu percebo cada vez mais que tem virado um nicho para as empresas o entendido de destinação do dinheiro público para projetos sociais. 


\section{APÊNDICE 5}

\section{Entrevista Imagemagica}

Eu sou Paula Blandy, sou diretora-presidente da ImageMagica.

Formalmente, com estatuto e tudo, a gente existe há 19 anos, informalmente porque teve uma época em que não estávamos ainda constituídos enquanto organização, 25 anos.

Ela é uma OSIP.

Sim, considero. Na verdade, todos os nossos projetos eles têm esse cunho sociocultural, usando a cultura como uma ferramenta de transformação para constituir um desenvolvimento social. Desde o nosso início, ou seja, 25 anos, a gente faz atividades, hoje a gente tem três grandes programas com vários projetos dentro de cada programa, então assim, a gente tem um programa que atende escolas públicas, a gente tem um outro programa que atende aos hospitais, e a gente tem outro programa que é de documentários do André. Então, são programas que anualmente a gente desenvolve, mas embaixo desses projetos são feitos vários outros projetos que não saberia te contabilizar. Hoje talvez a gente tenha em média uns 10 programas rodando, mas vai variar de ano para ano, de semestre para semestre e das parceiras que a gente faz.

A missão da ImageMagica é transformar as pessoas através da fotografia, é dar essa ferramenta de percepção para empoderar cada cidadão, mulher, homem, criança, independente da sua condição social, empoderar para que ele seja autor da sua própria história, na verdade é isso.

Sim, porque todos os projetos usamos a fotografia como ferramenta de transformação e leva essa fotografia para pessoas que não teriam nem condições financeiras nem condições geográficas de irem atrás dessa ferramenta.

A gente tem uma estrutura que é nosso núcleo de desenvolvimento institucional que organiza toda essa captação.

Na verdade, não, no começo essa captação não era estruturada em um núcleo, ela era feita por membros da equipe de maneira mais orgânica e menos estruturada, a partir de 2006 a gente acabou assumindo esse formato onde esse núcleo se tornou o responsável por fazer as captações.

Sim, o núcleo de desenvolvimento institucional escolhe parceiros para que a gente aumente nossa captação. Então essa terceirização vem no sentido de aumentar nossa abrangência de captação e a gente sempre busca esses parceiros, esses terceiros, entendendo um pouco da história deles, a gente não tem muitos parceiros para a captação, mas temos parceiros que a gente já vem trazendo há algum tempo.

Hoje temos 4 empresas parceiras para captação de alguns projetos. 
Esses parceiros ou nós chegamos neles porque estamos já interessados em alguma empresa para patrocínio, ou eles nos procuram porque temos projetos com a cara que as empresas parceiras deles estão procurando. Geralmente esse primeiro contato se dá assim, mas a gente tem que entender um pouco qual a missão dessas pessoas para a gente estabelecer uma parceira longa. Para organizarmos tudo isso, na verdade, a gente usa um sistema chamado Asana, que é um sistema de organização de projetos, onde a gente cadastra todo mundo e cada empresa que esse parceiro me pede a gente põe no nome dele, para evitar que duas empresas falem com o mesmo potencial patrocinador, então dentro desse nosso sistema está organizado se eu ponho uma empresa X que vai para o parceiro A, só o parceiro A fala com ela. A partir desse sistema que temos, organizamos todos esses relacionamentos.

Temos sempre uma parada no começo ano para fazer um planejamento anual do que a gente tem, a gente trabalha com várias leis de incentivo, tanto na cultura quanto na saúde, quanto infância. Hoje desenvolvemos uma outra linha de atuação, desenvolvemos o "não compreensivo" para prestação de serviço também. Então, a gente senta, e estabelece o budget do ano com o mínimo que temos de fazer para continuar com nossa missão em dia, para dar conta da nossa obrigação social, estabelecemos o que precisamos e vamos atrás. A gente tem reuniões de avaliação tanto para ver como está indo à captação, quanto para alinhar nossas rotas, porque nem sempre o que foi planejado vai ser executado de maneira tão quadradinha. Então a gente planeja por 1 ano o núcleo institucional, quando vamos para a diretoria, a gente tenta falar de um planejamento mais longo, então falamos em 5 anos, então eu e o André, que é o fundador, pensamos em projetos mais longos, vamos comprar uma sede ou vamos comprar uma outra unidade móvel, como se dá isso em um período maior.

Não.

Sim, um dos trabalhos desse núcleo institucional é realmente tentar entender no mercado quem pode ser um potencial parceiro, uma das coisas que a gente faz pensando, por exemplo, no Minc que tem o site da transparência, a gente dentro do nosso sistema a gente vai colocando os aportes que as fizeram empresas para a gente ter no radar tanto o potencial financeiro da empresa, como que tipo de projetos esses potenciais parceiros patrocinadores estão interessados. Isso acontece também com Proac, então a gente tem esse processo de pesquisas para editais e tudo, a gente alimenta o nosso sistema. Isso não é um período isso é uma coisa constante, do dia a dia, toda informação que a gente vai pegando no mundo a gente vai alimentando o nosso sistema, e a partir dai cada um tem uma lista de empresas, eu tenho a Sandra tem, de empresas que a gente vai ligar. O nosso foco é sempre marcar a reunião, particularmente a gente já entendeu em mais de 20 anos no mercado que só mandar um e-mail no caso de patrocínio, até pelas quantidades 
de coisas que as pessoas fazem hoje em dia, não funciona, mandar carta também não funciona. Então você tem que pegar no telefone e tentar marcar uma reunião onde a pessoa irá te olhar e entenderá melhor o seu projeto, e você consegue customizar, na medida do possível, essa proposta para o potencial parceiro. Quais são as necessidades deles que a gente pode, sem mexer na estrutura do projeto, levar em consideração para que possa ser um projeto atrativo para eles. Vamos por partes. Sim, eu tenho uma apresentação institucional, mas falando aqui pela minha experiência profissional, ela é menos acionada porque as pessoas têm menos vontade de ver esse tipo de apresentação. Fora a apresentação institucional a gente tem vários materiais do projeto, e sim, a gente fala da nossa missão. Porém, o que faz com que a pessoa preste atenção no que a gente esta falando é o nosso histórico, quando falamos tudo que já fizemos, as parcerias que temos, principalmente a parceria com a ONU, ele vai entendendo a credibilidade de quem a gente é, aí sim ele vai se interessar pelos projetos.

Não, não sabemos.

Para projetos da instituição.

Sim, na verdade não temos nenhum método para mantermos o relacionamento, mas procuramos falar sempre, atualizar as propostas, ver se precisam de ajuda. O que fazemos sistematicamente todos os anos é entrar em contato com esses terceiros para ver se eles têm a mesma lista de empresa, se eles desejam mudar. Então perguntamos, por exemplo, você está com a empresa $\mathrm{X}$, mas o ano passado você não mandou nenhuma proposta com ela, você deseja continuar com ela? Você não deseja continuar com ela? Então. podemos nós mesmos tentar? Então vamos tirar ela de sua lista. É nesse sentido que fazemos com os terceiros. Já com os patrocinadores, mantemos um relacionamento desde o início, e buscamos manter uma questão frequente e constante. Conforme ele tem mais contato com o projeto, melhor é para o projeto e para o relacionamento com empresa, então logo no primeiro mês ele já recebe um relatório de planejamento, ele recebe o relatório de acompanhamento todos os meses, no final a gente faz um fechamento onde vamos pessoalmente mostrar os resultados do projeto, e a gente tenta continuar mantendo a empresa ativa com outras propostas.

$\mathrm{Na}$ história da ImageMagica a gente tem vários tipos de parceiros, então por exemplo, temos empresas como a Roche que ficaram 8 anos fazendo projetos com a gente, aí depois dentro da própria empresa, se muda o foco, muda a linha de atuação, tem uma reformulação, aí essa parceria acaba não continuando. Mas, temos históricos de empresas como por exemplo a CCR, que estamos juntos há mais de 5 anos. Então, nossos projetos podem ser renovados sim, eles podem ser pontuais, as vezes o que acontece é que a empresa teve dinheiro em um ano e no outro ela não tem dinheiro, então ela não vai renovar; ou ela tem uma estratégia, em um ano ela 
apoiou o teu projeto, mas no outro ano ela quer apoiar o projeto de outra instituição. Sinto que quando as empresas estão estruturadas em seus investimentos culturais e socioculturais, é muito mais fácil entendermos a missão deles para fazer uma junção com a nossa missão e desenvolvermos projetos mais perenes. Quando as empresas são menos estruturadas acaba que muitas vezes temos projetos mais pontuais, pois uma hora ela quer teatro, noutra oficina, noutra livro, então os investimentos acabam sendo um pouco mais desestruturados.

Hoje um dos focos do desenvolvimento institucional é tentar desenvolver projetos sem leis de incentivos. Hoje todos os nossos projetos são através das leis de incentivos, independente das leis que sejam, mas são sim, todos através das leis de incentivo.

Hoje trabalhamos com lei Rouanet, Proac, Funcad, Pronas e Pronon.

Pessoa jurídica.

A gente tem uma linha de prestação de serviços, por exemplos nas escolas, de oficinas nas escolas, mas hoje são estou com nenhum projeto nesse sentido.

$100 \%$ leis e pessoas jurídicas.

Ela modificou um pouco, mas sempre o maior foi lei de incentivo, teve ano que conseguimos prestar mais serviços, teve anos que passamos em alguns editais, mas $80 \%$ sempre foi em leis de incentivo.

Não.

Sim. Concorremos com todo mundo que tem projetos aprovados, não posso hoje dizer que não concorro com quem, por exemplo, faz teatro, porque na verdade concorro. O recurso está ali, é um tanto o recurso, e todos os projetos estão atrás do mesmo recurso.

São 12 pessoas físicas que trabalham com contrato fixo, e são mais 10 pessoas com contratos temporários.

Mal, mas conseguimos. Anualmente mais ou menos 2 milhões e meio.

Aproximadamente 30 mil pessoas por ano no Brasil inteiro. 


\section{APÊNDICE 6}

\section{Entrevista Doutores da Alegria}

Eu represento o Doutores da Alegria, uma organização do terceiro setor sem fins lucrativos, minha função é analista de mobilização de recursos, eu sou responsável pela captação de pessoa jurídica.

O Doutores existe há 26 anos e atua no Rio de Janeiro, em São Paulo e em Recife.

Doutores tem dois grandes projetos, o primeiro entende todas as atividades da organização, nas cidades as quais eu falei, Rio de Janeiro, São Paulo e Recife, e um outro projeto que foca mais nas atividades de São Paulo que é o projeto apoiado por uma lei estadual. Então temos dois projetos.

O projeto maior, o projeto MAE ele existe há 26 anos, mas recebe apoio das leis de incentivo de 1992. O projeto menor, ele tem um tempo menor de existência, e ele está ativo desde 2007. A missão da instituição é levar arte e cultura ao público que vive em situação de risco e vulnerabilidade social, e que geralmente não tem nenhum acesso a arte. A gente propõe a arte como um mínimo social, assim como o transporte, a educação, que o cidadão também tenha acesso a arte como mínimo social.

Os projetos refletem a causa da organização que expandiu um pouco a sua atuação, saindo um pouco dos hospitais, que são o palco de origem dessas intervenções e se fortalecem como a escola que também oferece formação a esse público, esse público vulnerável e socialmente desprotegido pelo poder público.

O Doutores tem uma equipe bem enxuta, uma equipe bem pequena, então a estrutura ela é formada por uma pessoa que foca as captações de pessoas físicas, eu para as pessoas jurídicas, e nós temos também uma unidade de negócios que compõem a receita do Doutores como prestador de serviços, então a gente vende palestras, cursos, e esse valor ajuda a compor a receita.

Doutores já teve muitas experiências, mas inicialmente essa captação era realizada por terceiros, o Doutores não tinha uma equipe própria que buscasse essa receita, que ajudasse a trazer essa receita. Eu posso dizer que nos primeiros 10 anos da organização essa captação era realizada por prestadores, consultorias, e prestadores de serviços. Essa equipe ela é nova, ela existe desde 2004, ela tem 14 anos de existência.

Sim, nós temos a ajuda de alguns captadores, algumas consultorias que nos apontam negócios e que fecham negócios em nome da organização. 
Geralmente é feita uma análise do conceito de trabalho dessa consultoria. Se ela tem alguma sinergia com o Doutores da Alegria. É o único critério, uma boa conversa para alinhar as expectativas, então esse é o processo de seleção.

Sim, nós temos por volta de 10 ou 12 consultorias que trazem recursos também para os Doutores.

Isso é alinhado através de um contrato no qual vem mencionados pontos que olham pelas iniciativas do Doutores, e da prestação de serviços. Então a gente tem o contrato e tem também um processo que é alinhado com essas empresas de sinalizarem as negociações que estão em andamento, evitando conflito umas com as outras, ou até com a equipe do Doutores.

Sim, é pensada uma estratégia. A gente tem uma régua de ações mês a mês, a gente tem a compra de alguns mailings que ajudam a fortalecer a estratégia, a divulgar o projeto para um maior número de pessoas, a gente uma participação muito forte nas redes sociais, o que nos ajudam nessa captação, e ainda alguns eventos voltados para o nosso prospect, para essas empresas que estão conhecendo o projeto, assim como o convite para que elas conheçam o nosso trabalho nos hospitais, para conhecer de fato o nosso trabalho fazendo uma imersão nele. Então, essas são nossas estratégias.

Essa estratégia é elaborada anualmente, sempre no início do ano pensamento como iremos realizar o trabalho ao longo do ano. Geralmente a gente segue a estratégia, dos eventos, dos disparos dos e-mails, dos posts em redes sociais, a gente segue, apenas em 2016 a gente teve uma alteração, também como estratégia de captação de recurso, a gente teve um baile, um jantar de gala, comemorando os 25 anos da organização. Isso ajudou a compor a receita de 2016.

Não. Geralmente não.

Sim, a gente tem um mailing de divulgação do projeto, a gente tem um número muito expressivo nas redes sociais, então a gente divulga para essas pessoas, essa é a estratégia.

Através do disparo de email, e no caso de pessoa jurídico, o contato telefônico. A gente usa bastante essa ferramenta de ligar para as empresas tentar abrir portas.

Como organização do terceiro setor, uma instituição que a gente tem interesse em apresentar e, também, tentar entender se faz sentido para a empresa conhecer, é assim que a gente se apresenta.

Para os terceiros, geralmente a gente desenvolve um material que ajuda esse terceiro a abrir portas dentro das empresas.

A intenção é que sim, que saibam que conheçam e que também falem da nossa causa.

Para os projetos, para as atividades da organização. 
Sim. A gente procura se aproximar do parceiro, até para que ele entenda o nosso trabalho na essência, porque geralmente a empresa, a sociedade, conhece o trabalho do Doutores superficialmente. Para que a gente consiga renovar e manter essa parceria é fundamental que a empresa, o parceiro, entenda a fundo a importância desse trabalho, então a gente convida essa empresa para fazer uma imersão com a gente, através de eventos, de visitas no ambiente de hospital. A gente procura se aproximar com muitas ações durante o ano, café da manhã, conta causos, enfim...é importante que a gente tenha essa proximidade, até para garantir a continuidade dessa parceria.

Sim, são renováveis. E sim, acontece de não ser, isso é uma escolha da empresa continuar ou não, e aí envolve várias possibilidades, cenário financeiro, resultado dessa empresa, compliance muitas vezes, a gente tem um parceiro que por compliance da empresa não pode renovar ano a ano o projeto, ele tem que trocar de projeto anualmente, então isso é bem comum.

Dois projetos.

Eles existem com a força das leis de incentivo, mas a gente procura também trazer recursos próprios, trazer o apoio através de recursos próprios.

A ProAc ICMS do Estado de São Paulo e a Rouanet, que é uma lei federal de incentivo à cultura. Exatamente. O mais expressivo hoje são as leis de incentivo, elas respondem por $65 \%$ da nossa receita. E compomos essa diferença com apoiadores pessoa física, que apoiam através de leis de incentivo, ou não, são os sócios recorrentes geralmente; a gente tem campanhas de marketing relacionada a nossa causa, licenciamento da nossa marca, em alguns produtos que também ajudam a faturar a receita, e a venda de serviços, o Doutores oferece algumas atividades, principalmente para o público de RH's, que são muito bem avaliadas por esse segmento e contratadas, então a gente vende as palestras e outras intervenções que a organização produz. Não, elas vêm crescendo ano a ano. Eu posso dizer que há quatro anos atrás, as leis de incentivo elas respondiam por $51 \%$ da receita, mas elas vêm crescendo ano a ano.

Eu acho que o Doutores cada vez mais se consolida como uma organização séria, transparente e idônea, e eu também acho que isso está relacionado com as últimas questões levantadas sobre a lei Rouanet, aos escândalos, aos valores desviados, usados indevidamente. As empresas hoje olham muito para isso, aonde é que a gente vai aplicar esse recurso, a empresa tem que ter a segurança de que daqui a pouco ela não vai ser auditada ou punida por conta de um projeto malsucedido. Então o fato de o Doutores ser uma organização reconhecida, a gente tem uma consultoria independente que valida nossas contas, isso fortaleceu o Doutores, os últimos escândalos que a gente viu da Lei Rouanet não prejudicou as organizações que são sérias, e que 
são comprometidas, e auditadas, pelo contrário, fortaleceu, porque a empresa pensa duas vezes antes de direcionar esse recurso.

Eu acho que não. Eu acho fundamental a continuidade da possibilidade desse recurso vindo dessas leis. Eu acho que pelo percentual apresentado hoje, sobreviveríamos talvez, mas com uma mudança muito expressiva na organização, a gente teria que remanejar muita coisa, enfim, eu acho fundamental a continuidade.

Qualquer projeto que tenha saúde, hoje nos classificamos como cultura e saúde, mas os projetos que estão classificados como saúde concorrem com o Doutores da Alegria, nem tanto os projetos que se relacionam com educação, pois também nos classificamos com a educação, ou cultura, muito mais com os projetos da área da saúde.

Geralmente o contato o relacionamento com esses terceiros é feito por mim, que trato do jurídico, e com a Daniela que trata do relacionamento. Antes o Doutores, até esse ano, ele nunca tinha pensado numa aproximação mais, talvez, profissional com essa prestação de serviços, mas para 2018 a gente tem uma nova governança e um novo momento na organização, então desejamos reunir essas empresas e essas consultorias que tanto nos apoiam apresentando o projeto e levando a causa adiante, a gente pensa em reunir pelo menos duas vezes ao ano, nesse momento para falar desse novo momento da organização, e num segundo momento para tratar de detalhes mais técnicos como algumas cláusulas de contrato, que para uns é muito confortável e para outros não. Então, o Doutores também está revendo essa relação com o captador de recurso, porque ele quer que esse captador esteja mais infiltrado, mais dentro da causa, presentes no Doutores da Alegria não só nos momentos cruciais do ano que é a captação do Proac ou da Rouanet, a gente quer realmente um relacionamento mais consolidado, mais próximo e mais forte com essas empresas, pois muitas vezes a gente só conversa com essas empresas lá no fim do ano, que é o momento de captar a Rouanet, ou quando a gente tem um projeto, uma novidade, e aí corremos o risco deste prestador não estar tão atualizado com a nossas políticas de cotas, de contrapartidas, não estar tão atualizado de nossas políticas internas e isso pode impactar até com a empresa, então desejamos alinhar isso de forma bem redonda, para que todos estejamos falando de um único Doutores da Alegria. Apenas para se ter uma ideia, fomos numa de reunião com um cliente de uma empresa de consultoria pouco tempo atrás que já traz recursos para o Doutores, e lá nessa reunião a captadora não sabia que o trabalho realizado pelos artistas do elenco era remunerado, ela acreditava que era voluntário e que não era remunerado. Então precisamos evitar esse tipo de discordância, então o captador tem que estar inteirado do que é o projeto e dos novos passos da organização, para estarmos todos falando a mesma língua, com a mesma sinergia. 


\section{APÊNDICE 7}

\section{Entrevista Ibirajá}

A instituição é a Ibirajá Produções Artísticas Limitada. Eu dentro dos projetos que temos aqui, sou o produtor executivo.

A Ibirajá existe a 4 anos, fizemos 4 anos em dezembro de 2017.

No momento temos dois projetos ligados ao Ibirajá, temos o Cine Cena Brasil e o Cine Cena no Ar. Eles existem desde 2014, segundo semestre de 2014, na verdade o projeto se iniciou em setembro de 2014 e a empresa foi fundada em dezembro de 2013.

A missão da Ibirajá é levar o cinema para onde não tem cinema. Hoje não temos quase nada de cinemas nas ruas, mas sim em shoppings. Então nossa missão é continuar levando esse sonho de várias pessoas, esse projeto a pessoas menos favorecidas.

Sim, refletem, porque na maioria das vezes aonde estamos montados, com o auxílio dos patrocinadores, a maioria dos locais escolhidos são bairros de periferia, ou se são no centro, são em cidades muito pequenas, então o alvo são sempre esses locais e escolas municipais, estaduais. Mas, claro que já tivemos todos tipos de classes, porém nosso maior público são as escolas municipais.

Desde o início nós trabalhamos praticamente, num primeiro momento, com uma empresa de captação, captava com um patrocinador nosso, e que estava num primeiro momento suprimindo o que a gente necessitava nos dois primeiros anos, com um projeto que a gente havia inscrito, com várias cidades, e uma empresa só acabou captando o projeto inteiro. Do ano passado para este foi quando começamos a procurar novos captadores para mostrar nosso trabalho, mas é uma estratégia que está ainda sendo desenhada, a gente tem 4 anos de empresa, porém temos 3 anos de exibição de projeto rodando, mas ainda correndo muito atrás dessa questão da captação, a gente ainda não provou ainda a captação com outras empresas, estamos começando agora, com mais dois captadores que trabalharam com a gente, mas um que está chegando para mostrar nosso trabalho e para que a gente vá para outras regiões do país, então é uma estratégia que a gente ainda engatinha um pouco.

Sim, são terceirizadas que fazem a captação para a gente. Agora, nesse momento, tivemos uma empresa que virou instituto, portanto não temos mais o intermediário que captou o recurso, a gente negociou diretamente com a empresa. Mas, no restante sim, são captadores terceirizados. Muitas das empresas terceirizadas nos procuraram, a gente buscou algumas empresas para levar o projeto pensando mais para o Nordeste, mas falta um pouco dessas empresas naquela região. 
Nós temos hoje 5 empresas captando, mais ou menos. As empresas nos passam e nos perguntam informações como se outras empresas já se interessaram ou já apresentaram o projeto antes, e aí conseguimos controlar um pouco aonde está sendo apresentado o projeto, para que não tenha um problema de um captar na mesma empresa do outro, ou o projeto ser apresentado duas vezes por captadores diferentes.

Nos dois primeiros anos a gente tinha um só captador que acabava captando tudo, mas depois outros nos procuraram, porém foi meio o caminho natural, mas isso não quer dizer que a gente não possa tentar algo direto, porém ainda não temos esse caminho muito traçado.

Sim, como a gente é um projeto muito grande com inscrição em muitas cidades, complica muito para a gente quando o captador coloca questões como, a empresa y quer fazer uma cidade, um local só, e aí temos de analisar, pela dimensão do nosso projeto, se fazer em um local só compensa, então temos que analisar mais a questão de como executar o projeto junto com o captador.

A gente faz uma apresentação do projeto, quando é possível, pois as vezes é tudo muito rápido, fazemos uma apresentação do projeto presencial, para conversar um pouco. Ou o captador vem até aqui, ou nós vamos até ele, mas se ele quiser algo mais rápido mandamos uma apresentação via e-mail.

Na verdade, são dois lados diferentes da Ibirajá, buscamos o patrocinador para os dois projetos da Ibirijá, mas a Ibirajá como uma empresa sem fins lucrativos acaba precisando de buscar outras fontes de trabalho, como o trabalho de montagem de cinema fora dos projetos incentivados para que a gente tenha nosso sustento, para que consigamos nos sustentar. Só pelos projetos patrocinadores é quase impossível, pois apenas administramos o dinheiro do governo, então vamos para outros trabalhos como festivais e mostras de cinemas para nos sustentarmos enquanto empresa.

É difícil precisar, mas acredito que eles falem mais da causa do projeto levando em conta o histórico da Ibirajá.

$\mathrm{Na}$ verdade, há captadores que participam o tempo todo até o final, desde conversar com a empresa, até participar do evento, para ele conhecer o projeto montado, mas alguns a gente fala mais com a empresa, e outros com a empresa junto com o captador. E, às vezes, teve casos que nem quase falamos com a empresa, falamos mais com os captadores.

Até hoje nesses 4 anos trabalhamos com no máximo 5 empresas, então algumas empresas renovaram sim. As que não renovaram acredito que buscaram patrocinar outros projetos, seguir intercalando patrocinando projetos diferentes. 
No Cine Cena Brasil a média anual está em torno de 20 ou 25 montagens por ano, na estrutura do Cine Cena no Ar, podemos falar em 10 ou 15 montagens por ano.

Eles existem fora das leis de incentivo. Eles existem para que as empresas nos contratem separadamente para fazer alguns eventos pontuais, como já fizemos em festivais de cinema, eventos corporativos com o projeto. Mas quando a gente realiza esse tipo de projeto, que o objetivo não é levar o cinema a periferia, a gente não dá a ele o nome de Cine Cena no Ar, por exemplo, por conta desse projeto ter a marca de ir a periferia. A gente tem outra estrutura para ser usada como corporativo.

Jurídicas, leis de incentivo e editais.

Por percentual de projetos incentivados seria mais ou menos $80 \%$, os editais uns $5 \%$ no máximo, os demais podemos colocar 10 ou $15 \%$.

Ela modificou. No começo, por exemplo nos 2 primeiros anos, foi praticamente a lei de incentivo. Do 3 para o 4 ano, começamos a trabalhar com esses eventos externos, eventos diretos com essas empresas, fora as leis de incentivo.

Hoje acredito que não daria para sobreviver sem as leis de incentivo. Porque a lei nos ajuda com relação aos funcionários, a mover boa parte da Ibirajá. A gente tenta ter outros trabalhos diretos para que não tenhamos de sobreviver pelas leis, pois eles duram geralmente seis meses, acabando o projeto temos que sobreviver e não podemos depender apenas desse recurso.

No mesmo segmento não encontramos muito concorrentes, mas projetos similares de outros segmentos, por exemplo o teatro, temos a concorrência. Com os segmentos da cultura temos a concorrência, depende muito do que a empresa busca, do que o patrocinador quer seguir ou levar para as cidades que ele deseja atender. 


\section{APÊNDICE 8}

\section{Entrevista Cia Vagalum Tum Tum}

Meu nome é Christiane Galvan, minha instituição é a Vagalum TumTum, onde eu sou a fundadora, produtora, atriz e figurinista.

Há 16 anos.

Considero, porque a gente trabalha com teatro e sempre que possível a gente elabora projetos que contemplem pessoas de outras localidades, longe dos centros urbanos ou das capitais, para circular realmente com o teatro e levar para lugares sem muito acesso.

Diretamente não tem nenhum, a gente faz editais e dentro da proposta sociocultural deste edital, que geralmente exige uma certa contrapartida, a gente procura privilegiar ou um ingresso a preço popular ou, como acabamos de fazer recentemente, o prêmio Zé Renato, que foi contemplado e circulamos por seis CEUS levando todo nosso repertório de Shakespeare para as crianças, então a gente fez espetáculos todos os dias, além as escolas do CEU, vinha escolas de fora, foi um projeto bem legal, em que ficamos bastante felizes, era 450 crianças por sessão. A gente tem cinco espetáculos num repertório, então a gente pode trabalhar com eles separadamente com cada um deles num projeto, ou a gente pode trabalhar no formato de repertório, com todos juntos, todos são livremente adaptados das obras de William Shakespeare para criança, então tem uma linguagem um pouco comum em todos eles, e acho que é isso, ou você pode considerar o nosso trabalho inteiro um projeto, ou cada espetáculo inteiro um projeto. A gente ainda trabalha com oficinas, oficinas de formação; esse projeto, por exemplo, o Zé Renato, a ideia era levar a oficina de elaboração de projetos e a oficina sobre a linguagem teatral da Vagalum, levar no CEU. Mas, quando chegamos lá, como tinha mudado a prefeitura, eles não tinham mais contato com os grupos da região e tal, e aí chegávamos para a oficina para profissionais e tinham crianças para fazer a oficina, então conversamos mais com o pessoal do fomento do Zé Renato, o Departamento de Fomento à Cultura lá da Prefeitura, e aí trouxemos para nossa sede. Então, abrimos inscrições gratuitas, foi tudo muito legal, vieram bastantes jovens que desejavam entender como fazer um projeto cultural, a gente falou muito de nossa experiência, e elaboramos projetos fictícios, eles traziam projetos também para darmos uma olhada e dar uma assessoria, então isso também é uma forma de projeto social, você instrumentaliza artistas, ou jovens estudantes, para a realização do projeto deles também.

A gente tem, não é que esteja estabelecido, escrito na porta de entrada, mas a gente tem um projeto que pretendemos levar cultura e alegria a todas as crianças, aos pais, os acompanhantes, 
através do universo de William Shakespeare que ainda tem muito a nos ensinar, e até hoje a obra dele é muito atual e fala de questões que até hoje não resolvemos, ser ou não ser, eis a questão, enfim, a gente gosta de juntar os clássicos do teatro, com a linguagem do palhaço para contar essas estórias para as crianças e também para os pais, os pais também são nossos públicos, porque as crianças não vão sozinhas no teatro.

$\mathrm{Eu}$ acredito que refletem, ontem mesmo a gente fez uma apresentação no SESC Carmo, aberta e sem luz, e tinham muitos morados de rua que vieram assistir, muitas crianças que vinham e ficavam andando no meio da peça, então acho que as peças conversam, quando tem muita música, são estórias as vezes engraçadas, as vezes também mais reflexivas, então acho que a gente consegue se reconhecer em essa função social.

Não, a gente geralmente vai em busca de parcerias. Muitos dos projetos, principalmente em Lei Rouanet morreram na praia, passava dois anos e não conseguíamos captar. Nos últimos seis anos que a gente conseguiu parcerias com captadores, onde a gente conseguiu parcerias, como a $\mathrm{x}$ por dois anos, porque a gente conhecia um captador que veio conhecer nosso projeto e se interessou, apresentando depois para a xxxx, a gente ficou bem feliz, circulando com temporadas. Então a gente geralmente faz o projeto, e o edital pode já estar vinculado com o dinheiro, como por exemplo o Proac, ou na prefeitura de São Paulo, um fomento, ou a gente faz em São Paulo, com a Rouanet, ou a gente procura pessoas que possam trabalhar com ele, porque nós mesmo, a gente não consegue fazer isso, trabalhar com a parte cultural a parte estrutural do cotidiano, de manutenção de peça, do ensaio, e, captação, acho que a captação é uma coisa bem especifica que é feita por um profissional que chega numa empresa, que conhece a linguagem daquela empresa, sabe como mostrar nosso trabalho, de forma que a empresa se interesse por ele, talvez se fossemos fazer isso não iria dar tão certo.

Ela é terceirizada.

Geralmente é por pessoas que a gente conhece, que conhecemos em outros trabalhos.

No momento não temos, mas já tivemos momentos que trabalhos com J leiva? , com Sérgio Brandão, então eles avisam quando vão mostrar um projeto e antes de mostrar eles consultam a gente.

Porque não íamos dar conta de tudo.

A gente não tem muita estratégia nesse sentido, geralmente nossa estratégia é, queremos montar Ricardo III, então vamos fazer uma Lei Rouanet, porque vai que conseguimos captar, temos sempre essa esperança. E hoje em dia, se você cria um produto sociocultural você tem que colocar ele numa lei para você conseguir captar e fazer ele acontecer as vezes, é meio que automático. Então a gente acredita que seja sempre necessário ter um lei ou outra no bolso num 
dado momento, não tem nada pior que você ter um projeto, ter uma pessoa interessada e não poder fazer essa ponte, acho que as leis são a ponte entre o patrocinador e a gente e sem ela, não tem como fazer.

Não, a gente acaba conhecendo a estratégia quando começamos a trabalhar.

Geralmente é edital, edital prêmio, e as leis de incentivo. Mas a gente também trabalha muito para SESC's, acabamos de vender agora 42 apresentações para a prefeitura de São Bernardo, que quer fazer duas apresentações por dia em um mês. Então são coisas que vêm até nós porque conhece o trabalho, já ouviu falar. Assim, faremos o Hamlet para todas as crianças de escolas públicas de São Bernardo. São projetos que nos dão muita alegria.

Depende muito. A gente já percebeu que vem muito porque vamos atrás, tem que escrever, tem que ser lembrado, fizemos muito esse trabalho no final do ano passado, escrevemos para todos os SESC's da cidade, do interior, e isso aumentou nossa procura esse ano. E temos por missão nunca fazer nada de errado, não brigamos com ninguém, nenhum programador, nada. Buscamos sempre que tudo flua muito bem com muita qualidade no trabalho e nas relações, e sentimos nessas quase 2 décadas que isso retorna.

Acredito que seja sempre bom ter um material visual bacana, vender teatro me parece um pouco mais complicado porque se digo, aqui está o vídeo, veja o vídeo, jamais será mesma coisa, aquele foi um momento efêmero lindo que acontece só na hora, então a gente procura ter fotos boas, ter um bom fotógrafo, textos bacanas, um site bacana, ter uma página no Facebook, manter essa página atualizada esse site atualizado, para que a pessoa que não vai poder ver nosso produto ao vivo, pelo menos com esse material ela consegue ver que somos profissionais com qualidade, que realizamos aquilo concretamente de forma série e com um propósito nobre. Acredito que fale. Ao mesmo nas duas experiências diretas com captadores que tivemos, eles foram assistir as peças, acredito que seja muito difícil trabalhar com alguém na captação sem ao menos ver uma peça, tem que ver o teatro, porque ele só conseguirá com isso falar e mostrar melhor o trabalho. O Sérgio Brandão ia assistir nas cidades, na medida do possível ele estava lá, para o captador de recursos é muito bom saber que o produto que ele está oferecendo para a empresa é de qualidade.

Para a Vagalum.

Geralmente, a tenta manter, mas nem sempre conseguimos. Porque muitas vezes a empresa não está interessada nisso, mas a gente gostaria de um envolvimento mais profundo, do patrocinador, do captador, no mediador, todos. Isso não é fácil de conseguir, é muito difícil encontrar uma parceira bastante profunda por parte não só da empresa, mas também do 
captador. Há ainda muito a ideia da relação de mercado, no sentido de vendo você compra e é isso.

Nas experiências que tivemos houve renovação, e depois quando acabou eles buscavam investir mais em outros projetos da cidade onde a empresa mais atua e tudo mais. As vezes acho que o produto precise estar bastante vinculado na questão da cidade, de aparecer numa dada cidade, então as empresas do interior, tivemos a experiência de eles desejaram que priorizássemos lá, uma ONG de lá, um pessoal de lá. O que também é bacana.

Temos uma média de fazer um projeto novo a casa dois anos. Se for anualmente pensamos que perde um pouco de qualidade porque continuamos trabalhando com nosso repertório de 5 peças, e são 5 peças para manter em sua completude. As vezes pensamos a cada três anos, a cada dois anos, mas nunca menos que isso.

Independente. A maioria deles a gente fez sem leis de incentivo, ou com o SESC, ou algum edital, que também é lei de incentivo, mas é prêmio, não é captação.

Temos parcerias com o SESC, Teatro Alpha, Cultura Inglesa já nos apoiou, editais prêmios, Zé Renato da Prefeitura, Proac.

Acho que 60\% SESC e SESI, 20\% contatos que vêm até nós, prefeituras, festivais de teatro, circulamos muito com festivais, a geralmente não ganhamos um real, porque até com a verba do festival de teatro você paga transporte, hospedagem, cache e acabou o dinheiro. Zero, não sobra nada, porque buscamos sempre deixar uma sobra de 15 ou $20 \%$ para companhia, para Vagalum, para a manutenção, para pagar o alugar de sede, mas a gente sabe que é no festival que estão as pessoas que assistem os espetáculos, os olheiros que irão convidar para outros, então o festival é um lugar para você mostrar o trabalho, que deve ficar entre $10 \%$, e tem a captação que varia, depende das parcerias que temos. Esse ano acho que chegará a 30\%, mas varia muito.

Não, quando começamos além de ainda serem menos expressivas as leis, era difícil captar, a gente bancava nossos próprios projetos. Somos uma companhia com uma pesquisa, não temos atores globais, isso pesa muito, temos um produto artístico, mas isso dos atores ainda chama muito atenção dos patrocínios. O que procuramos trazer é algum tipo de inovação, tivemos uma ideia que não existia quem trabalhasse Shakespeare para as crianças, a essência das tragédias e dos dramas. E isso foi reconhecido, ganhamos prêmios aqui em São Paulo, todas nossas peças aqui apresentadas foram premiadas e isso é muito legal para o próprio patrocinador e captador que podem ver na gente um respaldo da crítica, mas isso só se consegue com o tempo. Quando fomos para Londres e pesquisamos no Globe o trabalho que as pessoas fazem sobre 
Shakespeare pelo mundo, vimos que ninguém no mundo fazia o que fazíamos, então esse ineditismo ajuda a gente a continuar, a ter um interesse no nosso trabalho.

Não dá, não daria para viver sem. Sem elas teríamos de viver de bilheteria, e não podemos cobrar um ingresso caro, essa conta não fecharia, temos em torno de 8 a 10 profissionais trabalhando numa sessão, e não podemos pagar todo mundo, não podemos ficar em cartaz sem um patrocínio, sem um prêmio, uma base.

Acho que concorremos com os famosos, com isso que a mídia mostra todo dia a população assiste sem questionar, e quer ver o ator que ele viu na novela, a atriz que ele viu na novela, acho que nossa maior luta é ainda contra a cultura que não te traz nada, contra uma cultura que te prende na frente da televisão o dia todo e te impede de ir ao teatro. Nosso maior concorrente são também os eletrônicos, as tv's, o que faz as pessoas não saírem de casa. Mas aqui entra nossa obrigação também, como fazemos um trabalho para crianças, temos a obrigação de formar uma plateia que é para o teatro, para a arte em geral, e esse trabalho temos visto os resultados nas conversas com as famílias que vão nos assistir, temos esse outro propósito também. E é muito importante que nosso trabalho seja de qualidade porque o público infantil se não gostar do teatro ali, dificilmente irá querer voltar. 


\section{APÊNDICE 9}

\section{Entrevista Pia Fraus}

Meu nome é Alberto Luís Andretta, meu nome artístico é Beto Andretta, e eu faço parte da empresa BuZum e da empresa Pia Fraus, duas empresas de teatro de bonecos.

Eu tenho um papel de direção artística. E, também, de discussão, de rumos, vamos dizer, tanto nos gerenciais quanto no quesito do artista, eu falo e defino rumos dos percursos artísticos das companhias, mas também discuto a gestão. Não exerço a gestão, mas faço parte da discussão dos moldes e das maneiras de se gerenciar, então eu tenho essas duas funções.

A Pia Fraus tem 34 anos de idade, em abril de 2018, ela completa 34 anos. Ela foi fundada em 1984.

Eu considero também, não só, mas também. Acho que esse recorte que você me deu é bem específico. É até uma das missões, vamos dizer assim, de ideologias e ideias que a Pia Fraus compartilha e exerce, mas ela não exerce só isso. Então, ela atende também um mercado que tem acesso tanto financeiro quanto geográfico ao espetáculo, nós não somos só isso que você classificou, mas somos também isso, porque grande parte dos espetáculos que a gente faz por ano, são voltados para esse tipo de ação que você falou, são lugares muito populares, muitos distantes, onde as vezes somos o único recurso teatral que essas pessoas tem acesso. Então, nós somos as duas coisas, somo e não somos só isso.

A vida da cultura ela é muito dinâmica, então se um dia você pode ter dois ou três projetos, no outro você passa a ter cinco ou seis, então muitos projetos como é a dinâmica da cultura no Brasil, você dificilmente consegue um grande planejamento, você pode se planejar, mas o mercado não te deixa muito planejar. Então, hoje, por exemplo, o que a Pia Fraus está fazendo, ela está fazendo um curso de formação, junto com o BuZum, de teatros de bonecos, para 35 pessoas, ela tá fazendo todo um circuito de apresentações em bibliotecas públicas da cidade de São Paulo, via também lei do fomento. Então na própria lei do fomento, nós já temos dois eixos, na própria lei do fomento tem mais um eixo que é as apresentações nas casas de cultura, com a apresentação Gigantes de Ar, então hoje, pelo fomento nós temos 3 atividades. Fora isso, hoje a gente está recebendo escolas aqui na sede da Pia Fraus, Escolas particulares, que pagam para vir aqui, então são 4 ações teatrais. E, estamos na expectativa de realizar um projeto pelo ProAc, já temos dois aprovados, então a partir de abril, essas quatro ações podem passar a ser seis, e se você considerar como ação toda apresentação teatral, a gente tem a Caixa Econômica Federal programada, e mais meia dúzia de apresentação programa em lugares diversos, SESC's, SESI's, Prefeituras. Então eu diria hoje que a Pia Fraus está envolvida em maios ou menos umas 10 
atividades culturais, no ano passado em 2017 a gente fez 180 apresentações teatrais. Então esse é o panorama do que estamos fazendo hoje em dia.

O fomento temos mais 3 meses, várias atrações terminam em junho. As apresentações, o ProAc, se captarmos, teremos duração de mais 3 meses. Então, teremos mais ou menos de maio a setembro, se captarmos. A questão das apresentações é uma atividade perpétua, todos os anos fazemos pelo menos 100 espetáculos isso não para a mais de 10, 12 anos, então é constantemente. Com um grupo do nosso perfil, temos vários outros em São Paulo, muito focado em teatros para criança, é um grupo que é considerado pela crítica, pelo público, tem uma qualidade, então existe esse mercado constante em São Paulo. Com um grupo do nosso porte dá para fazer de 80 a 100 espetáculos por ano, então é continuo. Nunca para, e isso não pode parar, muito difícil um mês que a gente não realize dois ou três espetáculos.

A Pia Fraus, mais do que missão, tem um desejo de continuar existindo, basicamente assim. Continuar existindo dentro dos cânones mais ou menos que regem. Continuar praticando um tipo de teatro com bonecos e atores, continuar essa linguagem tão característica. Aqui em São Paulo, quase todos os grupos se caracterizam por uma maneira de fazer teatro, que é chamada linguagem, porque teatro é teatro e você pode fazer de diversas maneiras. A Pia Fraus tem uma linguagem que é coerente desde o começo, que é integração de várias áreas, artes plásticas, dança, teatro, circo, a gente tem feito uma fusão de varias linguagens, que resultam numa linguagem nossa. Então é essa nossa missão, dar continuidade a isso de forma coerente. Nós não abrimos mão dos nossos anseios artísticos, de pesquisas de temas, a gente não se dobra a modismos, a gente lança moda. Sempre discutimos o universo infantil de maneira profunda, seja ele preservação e meio ambiente, amizade, o universo familiar, sonhos, angústias, o que nos interessar naquele momento a gente tenta colocar em cena, sem muita preocupação mercadológica. Então acho que temos uma coerência nesse sentido.

Sim.

Não existe na verdade, no fundo acho que nem no BuZum existe uma estrutura, o que existe no mercado hoje, acho, aqui no Brasil, em São Paulo, são esses personagens chamados captadores que vieram preencher uma lacuna no mercado cultural, eu sou de uma época, eu pratico arte desde 1980, nos 80 não tinham leis de incentivo na cultura, eram pequenas chamas que aconteciam, eram projetos que iam e terminavam, acabavam, a primeira lei do fomento na cidade de São Paulo é de 2003, então eu passei a década de 80 e de 90 . A primeira verba que eu lembro de ter ganhado ter forma significativa para montar algum espetáculo foi em 1996, que era a estreia dos teatros de bairro com uma peça chamada Flor da Obsessão, era uma verba pública, mas em forma de um pequeno edital. Então, desde esse momento aonde começa essa 
política em meados dos anos 90 nas leis, ela desagua hoje também nos captadores. Então, hoje a nossa técnica, a gente não tem uma estrutura para buscar isso, o que temos é a simpatia de vários captadores, temos um produto que os captadores entendem que tem uma interlocução com as empresas, e por isso a gente é relativamente bem-sucedido. A partir do momento, e entendendo isso, nós também na formulação dos projetos a gente começamos a levar a preocupação, sem abrir mão do conteúdo que queremos fazer, ou da maneira que queremos fazer, mas de uma maneira criativa, a gente percebe essa tendência de mercado e esse poder das empresas, então a gente consegue desenvolver os produtos como queremos, mas também como as empresas imaginam. O que nós fazemos é isso, temos a sensibilidade de criar projetos que possam ser bem aceitos nesse mercado, mercado esse que é regido não só pelas leis culturais, então tem muita coisa de atratividade, de chamar a atenção da cidade, então você criar coisas que dialoguem com o marketing sem perder a profundidade da linguagem. Então a nossa estrutura da captação está muito ligada a forma dos projetos que atraem os captadores. Até porque é uma relação muito particular a que se estabelece entre captador e empresa, eu por exemplo, nunca estabeleci nem com a Pia Fraus nem com o BuZum, eu diretamente nenhuma relação intima com uma empresa a ponto de levar um projeto cultural meu, por isso me valho desses personagens.

$\mathrm{Na}$ verdade, desde a primeira captação se deu de uma maneira muito informal. Depois houve um hiato muito grande e ficamos só na questão das verbas públicas, que pressupõe a não participação de um captador, então não precisava da figura do captador. Depois a figura do captador se apresentou na nossa vida, mas já havia passado quase 15 anos sem que tivéssemos gozado de uma lei nesses moldes. E quando apareceu, um captador se apaixonou pelas nossas ideias criativas e foi quem intermediou uma grande parte dos nossos recursos do BuZum. Com a Pia Fraus começa uma novidade que se chama ProAc, eu criei um projeto teatral que se chama Teatro Portátil, que eu faço um espetáculo dentro da estrutura, e eu percebi que isso chamou a atenção dos captadores se aproximaram via internet. Eles viam os projetos aprovados e nos contatavam já com algumas empresas engatilhada. Esses captadores novos que apareciam e viam uma nova possibilidade. No BuZum agora a gente faz mais um movimento em direção aos captadores, e aqui também, na Pia Fraus, propomos, mostramos, temos esse movimento um pouco mais agressivo.

No Brasil nos anos 90 e 2000, existiu uma grande quantidade de editais, embora agora esteja mais fraquinho, mas entre Fernando Henrique e Lula, existiu, e criou-se uma política de editais públicos, e por isso a gente nunca sentiu a necessidade de ir para fora, sempre estivemos muito atentos a esses editais públicos, sempre participando. 
Oito ou nove, não chega a dez aqueles tem projetos nossos hoje para mostrar para os outros. A gente pede para esses captadores avisarem para quem eles pretendem mostrar nosso produto para não ter choque de vir por duas vias diferentes. Quem nos diz primeiro que irá apresentar para aquele cliente, leva. Não temos uma reserva nesse sentido.

Não temos critérios nenhum na verdade, a gente tenta estabelecer bons relacionamentos com todos. Sem impedimentos de localização, estado, quanto mais estivermos representados hoje, melhor para o grupo, é assim que entendemos hoje; então não tem um critério: ah essa empresa já conseguiu tanto então vamos ficar só com ela, não, quem chegar a gente quer. Queremos pessoas interessadas em nos representar, é interessante para nós esse sistema.

Não é que escolhemos, na verdade a Pia Fraus nasceu a 34 anos atrás e já muitas coisas que a Pia Fraus faz hoje não foram escolhas, o tal mercado, essa força abstrata ela existe, tanto que nós já criamos vários espetáculos adultos, e fomos bem sucedidos, mas somos vistos hoje como um grupo que se dedica as atividades infantil, não foi uma escolha, foi uma questão de demanda. O que tem o resultado a gente opta, então não resolvemos terceirizar, as coisas se apresentaram dessa maneira, e nunca tentamos ocupar esse lugar, nunca pensamos em fazer, porque já chegou desse jeito para nós e nós continuamos.

Me parece ser quase uma fantasia a captação de recursos sem lei; eu não conheço nenhum projeto de amigo que tenha recebido dinheiro, valor, patrocínio direto desinteressado. Algumas coisas pontuais são mantidas por pessoas que tem muito dinheiro e investem nisso, mas são poucas. Então, nunca tivemos patrocínio direto, e até desconheço quem goze disso no Brasil.

A gente faz sim, aqui eu tenho uma parceria que me ajuda muito a vir para a realidade, eu tenho um sócio que não é, vamos dizer, artista, mas que tem a sensibilidade do fazer arte, então ele me traz uma realidade, ele me apresenta o movimento dos espetáculos, qual mais vendeu, como foi cada um, então hoje temos claro para o ano de 2018 seria muito importante conseguir um ProAc, então vai começar agora a temporada de caça, temos 3 projetos aprovados, e ele me aponta o que precisa fazer, o que seria melhor fazer. Já percebemos, por exemplo, que peças muito grandes com muitos atores não têm mercado que absorva, não leva a nada, e por mais que eu tenha desejo, ele me traz a realidade e tudo mais. Então esse meu sócio, o Jackson, me ajuda muito nisso tudo, em estabelecer focos, desejos. Existe então essa técnica, essa discussão. Os captadores não estão muito presentes nas nossas vidas, no sentido de estar sempre aqui, não temos nenhum captador que vem discutir essas estratégias com a gente. Tivemos apenas um, para falar a verdade, que discutia bastante conosco, as questões do caminho e tudo mais, o J Neiva, foi o mais presente nas discussões para o próximo ano, os outros não, eles se dão por contente em nos vender. 
Como o Jackson me apresenta os números todos os anos, de seis em seis meses, ali a gente traça um perfil dos nosso clientes, no perfil do nossos clientes, a gente entende que o SESC é um grande comprador, que os festivais de teatro são grandes compradores, então a gente tem uma estratégia e de tempos e tempos temos que mandar e-mails para o SESC, para lembrar, porque a concorrência é muito grande. Então, existe sim toda uma discussão para saber qual seria o nosso cliente em potencial, estamos com toda certeza atentos a isso.

Eu acho que fazemos uso das duas coisas, a gente apresenta um projeto com o peso da instituição. A gente sabe o peso que temos, somos um grupo antigo, que já ganhou muita coisa, e isso tem um valor para o mercado. Mesmo o BuZum que já é independente a gente ainda percebe uma influência do Pia Fraus ali. Então sim, usamos bastante o peso do grupo, de ter viajado já internacionalmente, então jogamos o histórico que é razoável junto com o projeto, é uma junção dos dois fatos.

Também, da mesma forma. A gente sempre agrega nas discussões o valor da mídia que tivemos, fazemos uso desse suporte em qualquer momento.

A gente busca para os projetos. Existem até um tipo de projeto que outros grupos fazem, mas nós não fazemos, que é tipo um projeto de manutenção, só para continuarmos existindo, mas nunca fizemos um nesses moldes, aliás, para falar a verdade fizemos um agora, para o Itaú Cultural que pressupõem a criação de um acervo, totalmente voltado para o enriquecimento da nossa linguagem, mas esse foi o primeiro.

Nesses anos todos se têm uma coisa que já percebemos é que não podemos obrigar as pessoas que dão recursos na manutenção do contato. Poucas são, a CCR é uma grande exceção, aquelas que acompanham, que fazem uma estratégia com o grupo. E captadores também, muito não querem contato muito íntimo, não desejam ver os projetos que eles próprios captaram.

Eu acho que é uma cultura do business das empresas. Muito poucas empresas tem um cuidado com essa gestão dessas leis, eu realmente percebo que para muitos é quase um estorvo, dá um pouco de trabalho para saber como usar. E existe também uma rotatividade muito grande dos executivos. Uma vez tivemos uma empresa que fechamos, foi ótimo, fizeram uma avaliação positiva, dizendo que no próximo ano estariam conosco, havia uma menina de $\mathrm{RH}$ muito envolvida, muito interessada, mas ela engravidou, e aí entrou outra pessoa sem o menor entendimento, sem a menor paixão daquilo que foi realizado, e então suspendeu-se a verba, a continuação da verba. Nas empresas muitas vezes as pessoas que são deslocadas para fazer esse trabalho não são bem preparadas, não há uma política definida. Acho que talvez seja essa a razão de não haver continuidade, de ser esporádico, e depois começar de novo. 
A Pia Fraus ela consegue existir sem leis de incentivo, de uma maneira meio difícil, mas ela conseguiria, desses 6, 4 não tem leis de incentivo, que é a permanecia. Conseguem, mas uma vez que o projeto nasce incentivado ele não consegue sobreviver sem isso. Quando tem o incentivo faz toda a diferença e muitos projetos param sem ele.

ProAc e Rouanet. Até porque não acho que haja ainda outras.

Falando na Pria Fraus, no ano passado 50\% foi ProAc, os 50\% são diluídos entre SESC, com $60 \%$ dessa outra metade, a Secretaria Municipal de Cultural, estadual e Municipal devem chegar perto de $20 \%$ disso, escolas foram significativas também, e um evento ou outro, um festival, por exemplo. O peso do SESC é muito grande, no quesito compra. No ano passado foram esses os números, mais ou menos.

Eu acho que nem sempre foi esse percentual, até porque começamos a atuar num momento que o SESC ainda não ditava o mercado. A minha primeira atividade no SESC foi em 1983, antes mesmo da Pria Fraus, mas o SESC dá um grande salto, e desenvolve seu entendimento do seu papel cultural, com a administração do Danilo. Quando começamos as prefeituras tinham um papel muito mais forte que hoje, elas compravam a cultura, prefeituras do interior de São Paulo, eu fazia Rio Claro, Ribeirão Preto, Jundiaí, Limeira, com verbas municipais, não com verbas do estado. Então as prefeituras tinham um outro papel, elas perderam esse protagonismo, que foi um pouco para as mãos do SESC. Existia outro sistema que aos poucos foi se inibindo.

Eu acredito porque a gente está buscando forma. Essa sede que estamos lançando é uma tentativa real de ter uma possibilidade que independa das leis e desse mercado que é dado, com SESC e prefeituras. Então, estamos tentando com a abertura desse lugar uma nova forma de financiamento da nossa atividade artística. Então, se aqui for bem-sucedido podemos sobreviver, mas caso contrário acho bem difícil.

Pessoas envolvidas conosco, temos aqui 6 pessoas gerenciais, no sentido de estar envolvida na organização direta do escritório. Temos um grupo de aproximadamente 20 atores que estão ligados de alguma maneira em nós, porque não temos um grupo fixo de atores, eles vão em vem, de acordo com a disponibilidade, não temos nenhum CLT, temos uns 5 técnicos também, e quando montamos um espetáculo, mais uns 6. Hoje no nosso universo circula então mais ou menos umas 40 pessoas.

A consegue sim sobreviver, mais pegamos um boom de leis no começo dos anos 2000, de 2000 a 2010, a gente viveu um grande sucesso no processo de editais, internacional, foi uma década muito boa, muito forte financeiramente e de projeção. Depois de 2010 a 2016, tivemos uma certa dificuldade de esgotamento, de ideia de grupo, nas comissões de avaliação, que acaba sendo os mesmos nomes, então teve uns 6 anos mais difíceis. Em 2016 voltou a melhorar um 
pouco e, hoje em dia ela vive um ponto de equilíbrio perigoso, ela paga seu custo, o meu salário e do Jackson está bem defasado, a gente não é deficitário, mas também não é lucrativo, deixou de ser, durante uma época fomos lucrativos nos termos teatrais. No ano passado a gente faturou 900 mil reais entre leis e espetáculos, mas usamos tudo. O que fizemos esse ano já gerou um equilíbrio até o meio do ano, até julho estamos ok, mas se depois de julho não fecharmos um ProAc talvez fechemos negativo. Mas, até hoje não se apresentou uma situação de prejuízo, dentro desses esforços e colaboração dos proprietários, que sou eu e o Jackson a gente consegue um certo equilíbrio. A gente acabou de abrir a sede e estamos com uma demanda interessante, mas ainda não estamos num ponto de equilíbrio. Embora acreditamos que será bem-sucedida, mesmo que não represente $50 \%, 60 \%$ que a gente deseja, talvez represente para não termos prejuízo, caso não fechemos com as leis. 